\title{
Eastern Caribbean Currency Union: 2017 Discussion on Common Policies of Member Countries-Press Release and Staff Report
}




\section{INTERNATIONAL MONETARY FUND}

IMF Country Report No. 17/150

\section{EASTERN CARIBBEAN CURRENCY UNION}

June 2017

\section{DISCUSSION ON COMMON POLICIES OF MEMBER COUNTRIES-PRESS RELEASE AND STAFF REPORT}

Under Article IV of the IMF's Articles of Agreement, the IMF holds bilateral discussions with members, usually every year. In the context of the 2017 Discussion on Common Policies of Member Countries, the following documents have been released and are included in this package:

- A Press Release summarizing the views of the Executive Board as expressed during its June 2, 2017.

- The Staff Report prepared by a staff team of the IMF for the Executive Board's consideration on June 2, 2017, following discussions that ended on April 13, 2017, with the officials of Member Countries of the Eastern Caribbean Currency Union on economic developments and policies. Based on information available at the time of these discussions, the staff report was completed on May 18, 2017.

- An Informational Annex prepared by the IMF staff.

The documents listed below have been or will be separately released.

Selected Issues

The IMF's transparency policy allows for the deletion of market-sensitive information and premature disclosure of the authorities' policy intentions in published staff reports and other documents.

Copies of this report are available to the public from

International Monetary Fund • Publication Services

PO Box $92780 \bullet$ Washington, D.C. 20090

Telephone: (202) 623-7430 • Fax: (202) 623-7201

E-mail: publications@imf.org Web: http://www.imf.org

Price: $\$ 18.00$ per printed copy

\section{International Monetary Fund Washington, D.C.}


Press Release No. 17/222

FOR IMMEDIATE RELEASE

June 14, 2017
International Monetary Fund

$70019^{\text {th }}$ Street, NW

Washington, D. C. 20431 USA

\section{IMF Executive Board Concludes 2017 Discussion on Common Policies of Member Countries of the Eastern Caribbean Currency Union}

On June 2, 2017, the Executive Board of the International Monetary Fund (IMF) concluded the 2017 discussion on the common policies of the Eastern Caribbean Currency Union (ECCU) in the context of the Article IV consultations with member countries. ${ }^{1}$

Favorable external conditions continue to support economic recovery, but flat tourism receipts and falling revenues from citizenship programs have weakened growth. The fiscal position has deteriorated slightly and public debt remains high. Despite progress on financial sector reform, bank lending continues to decline while indigenous banks' profitability is adversely impacted by increasing costs to secure correspondent banking relationships. The short-term outlook is favorable and risks are broadly balanced, but strong structural policies are needed to address impediments to medium-term growth.

\section{Executive Board Assessment ${ }^{2}$}

Executive Directors welcomed the favorable short-term outlook, supported by solid tourism inflows, low oil prices, and steady foreign direct investment. Directors noted that while risks are broadly balanced, the ECCU is vulnerable to external shocks, policy slippages, and natural

\footnotetext{
${ }^{1}$ Under Article IV of the IMF's Articles of Agreement, the IMF holds bilateral discussions with members, usually every year. In the context of these bilateral Article IV consultation discussion, staff hold separate annual discussions with the regional institutions responsible for common policies in four currency unions - the Euro Area, the Eastern Caribbean Currency Union, the Central African Economic and Monetary Union, and the West African Economic and Monetary Union. For each of the currency unions, staff teams visit the regional institutions responsible for common policies in the currency union, collects economic and financial information, and discusses with officials the currency union's economic developments and policies. On return to headquarters, the staff prepares a report, which forms the basis of discussion by the Executive Board. Both staff's discussions with the regional institutions and the Board discussion of the annual staff report will be considered an integral part of the Article IV consultation with each member.

2 At the conclusion of the discussion, the Managing Director, as Chairman of the Board, summarizes the views of Executive Directors, and this summary is transmitted to the country's authorities. An explanation of any qualifiers used in summings up can be found here: http://www.imf.org/external/np/sec/misc/qualifiers.htm.
} 
disasters. With this background, Directors recommended implementation of stronger policies and structural reforms to address vulnerabilities, enhance resilience, and improve growth prospects.

Directors underscored the need to place public debt on a path consistent with the 2030 regional benchmark of 60 percent of GDP, while a few Directors called for a ceiling at this level. The adoption of credible fiscal frameworks, strengthened by fiscal responsibility legislation where appropriate, would help achieve the debt target. Directors stressed that sound management of the public sector wage bill is critical for fiscal consolidation. The decision by the Monetary Council of the central bank to discuss members' medium-term frameworks and interim fiscal targets is a useful step, but determined implementation will be key.

Directors emphasized the need to prepare for natural disasters and build resilience, including through investment in infrastructure and ex-ante financing arrangements which are fully integrated in macroeconomic frameworks. Revenues from Citizenship-by-Investment (CBI) programs, which should be used to reduce public debt where necessary, can also be directed to saving funds and to finance appropriate investment plans. Directors suggested that a regional approach to CBI programs would help strengthen the integrity of these programs while reducing their costs.

While recognizing steps taken by the ECCB, Directors noted that weaknesses remain in the financial sector, with banks still burdened by high nonperforming loans. They highlighted the importance of enforcing prudential requirements based on a realistic assessments of banks' capital needs. Prompt activation of the Eastern Caribbean Asset Management Company would accelerate banks' disposal of their bad assets. Directors also encouraged early completion of key legislation, including a harmonized law on asset quality, a stronger regulatory framework for credit unions and insurance companies, and new insolvency legislation.

Directors suggested that the cost of securing correspondent banking relationships can be reduced through stronger AML/CFT legislation and supervision, bank consolidation, and improved communication. They also noted that removing the saving rate floor would improve the functioning of credit markets. Efficiency enhancements in the Regional Government Securities Market would help lower borrowing costs and improve financial intermediation.

Directors stressed that accelerating structural reforms is necessary to address high unemployment, raise competitiveness, and boost growth prospects. Priorities include reducing costs of doing business and speeding up the implementation of renewable energy projects. Directors noted that furthering regional integration would help achieve economies of scale and enhance competitiveness. Strengthening the link between wages and productivity would help address structural unemployment.

Directors welcomed recent improvements in the quality of statistics and data provision, and encouraged further progress to enhance the quality of surveillance and policy analysis. 


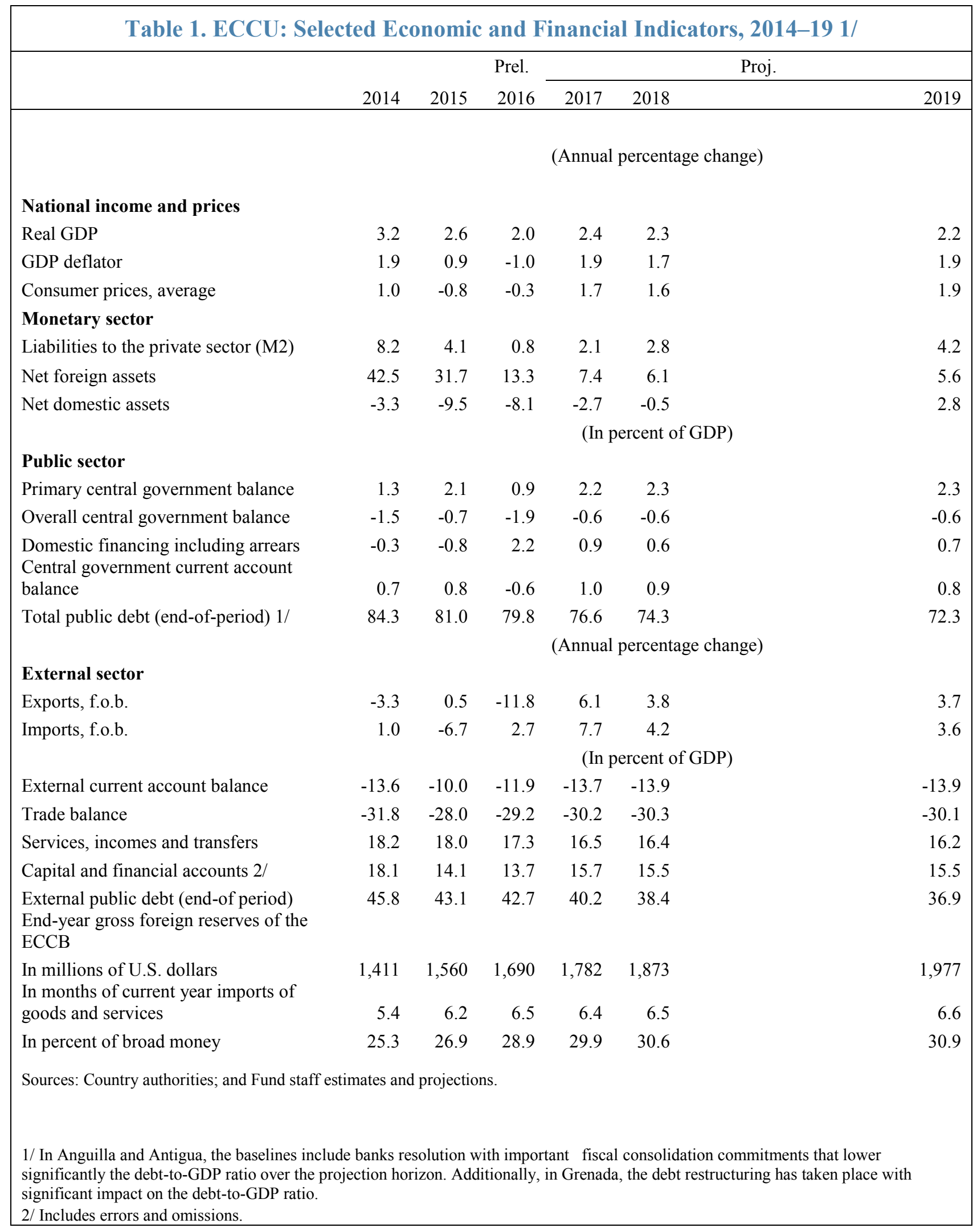




\section{INTERNATIONAL MONETARY FUND}

\section{EASTERN CARIBBEAN CURRENCY UNION}

\section{STAFF REPORT FOR THE 2017 DISCUSSION ON COMMON POLICIES OF MEMBER COUNTRIES}

Under Article IV of the IMF's Articles of Agreements, the IMF holds bilateral consultations with members, usually every year. In the context of the 2017 ECCU Common Policies Discussion, the mission held policy discussions with the Governor of the Eastern Caribbean Central Bank (ECCB), senior officials of the Caribbean Development Bank (CDB) and of the Organization of Eastern Caribbean States (OECS), financial sector regulators, and representatives of the private sectors.

\section{KEY ISSUES}

Favorable external conditions continue to support economic recovery, but flat tourism receipts and falling revenues from citizenship programs have weakened growth. Fiscal vulnerability remains a concern, with most ECCU members not reaching the 2030 public debt target of 60 percent of GDP on current policies. Despite progress on financial sector reform, bank lending continues to decline. Risks are broadly balanced, but stronger fiscal and structural policies are needed to lower debt and address impediments to medium-term growth.

\section{Main Policy Recommendations:}

Addressing fiscal challenges: Adopt fiscal responsibility legislation to strengthen the commitment to the debt target; use, where possible, deposit cushions to lower debt; pro-actively manage the risk of natural disasters; increase regional coordination to reduce costs, preserve revenues, and contain reputational risks of citizenship programs.

Strengthening the financial sector: Complete implementation of the regional strategy, including by setting up the regional asset management company and strictly enforcing capital requirements; strengthen regulation and supervision and improve communications to secure correspondent banking relationships.

Structural Issues: Reduce fossil fuel dependence including to reduce energy costs; enhance the business climate; strengthen connectivity; tighten link between wages and productivity. 
Approved By

Trevor Alleyne (WHD) and Bob Traa (SPR)
Mission: Discussions took place in Basseterre, Bridgetown, and Castries on April 4-13, 2017. The staff team comprised Leo Bonato (head), Alejandro Guerson, Alla Myrvoda, and Dominique Simard (all WHD). Trevor Alleyne (WHD) and Mike Sylvester (OED) participated in the discussions in Basseterre and Ann Marie Wickham (local economist, WHD) joined the team in Basseterre and Bridgetown. Annette De Kleine Feige (World Bank) accompanied the mission. Staff met with ECCB Governor Timothy Antoine, senior officials from the OECS Commission and the Caribbean Development Bank, financial system regulators, and representative of the financial sector.

Contributors: ECCU team (L. Bonato, A. Guerson, A. Myrvoda, D. Simard, H. Yun); F. Di Vittorio, D. Hess, G. Impavido, R. James, W. Mitchell, G. Salinas (all WHD), and D. Rivetti (MCM). S. Tibung and M. El Kawkabi prepared the document and provided administrative assistance.

\section{CONTENTS}

Glossary

A. Strengthening the Fiscal Policy Framework to Address Sustainability Challenges___ 11

B. Strengthening the Financial Sector ___ 14

C. Enhancing Competitiveness and Boosting Potential Growth __ 18

STAFF APPRAISAL

\section{BOXES}

1. Potential Growth__ $\underline{9}$

2. Risk Assessment Matrix (RAM) _ 10

3. Fiscal Rules__ $\underline{13}$

4. The Consolidation of Indigenous Banks __ $\underline{15}$

\section{FIGURES}

1. Real Sector Developments___ $\underline{24}$

2. Tourism Developments __ $\underline{25}$

3. Monetary Developments __ $\underline{26}$ 
4. Financial Soundness Indicators $\underline{27}$

5. Doing Business Indicators $\underline{28}$

\section{TABLES}

1. Selected Economic and Financial Indicators, 2010-22 $\underline{29}$

2. Selected Economic Indicators by Country, 2010-22 $\underline{30}$

3. Selected Central Government Fiscal Indicators by Country, 2010-22 $\underline{31}$

4. Selected Public Sector Debt Indicators by Country, 2010-22 $\underline{32}$

5. Monetary Survey, 2010-18 $\underline{33}$

6. Summary Balance of Payments, 2010-22 $\underline{34}$

7. Selected Labor Market Indicators

\section{ANNEXES}

I. Implementation of Previous Staff Advice $\underline{36}$

II. Citizenship-By-Investment Programs $\underline{43}$

III. Central Government Wage Bills $\underline{48}$

IV. Public Investment Management $\underline{51}$

V. The Regional Government Securities' Market $\underline{53}$

VI. External Sector Assessment $\underline{55}$

VII. United Kingdom Overseas Territories-Anguilla and Monstserrat $\underline{59}$ 


\section{Glossary}

$\begin{array}{ll}\text { AML/CFT } & \text { Anti -Money Laundering and Combating the Financing of Terrorism } \\ \text { BPM6 } & \text { Balance of Payments Manual 6 } \\ \text { CARTAC } & \text { Caribbean Technical Assistance Centre } \\ \text { CBI } & \text { Citizenship-By-Investment } \\ \text { CBRs } & \text { Correspondent banking relationships } \\ \text { CDB } & \text { Caribbean Development Bank } \\ \text { ECAMC } & \text { Eastern Caribbean Asset Management Corporation } \\ \text { ECCB } & \text { Eastern Caribbean Central Bank } \\ \text { ECCU } & \text { Eastern Caribbean Currency Union } \\ \text { EDF } & \text { European Development Fund } \\ \text { FATF } & \text { Financial Action Task Force } \\ \text { FDI } & \text { Foreign Direct Investment } \\ \text { FRL } & \text { Fiscal Responsibility Legislation } \\ \text { KYC } & \text { Know Your Customer } \\ \text { MSR } & \text { Minimum Savings Deposit Rate } \\ \text { NPLs } & \text { Non-performing loans } \\ \text { NTF } & \text { National Transformation Fund } \\ \text { OECS } & \text { Organization of Eastern Caribbean States } \\ \text { PFM } & \text { Public Finance Management } \\ \text { REER } & \text { Real Effective Exchange Rate } \\ \text { RGSM } & \text { Regional Government Securities Market }\end{array}$




\section{RECENT DEVELOPMENTS}

\section{Economy activity decelerated in 2016, reflecting flat tourism receipts and falling} revenues from citizenship programs. GDP growth fell slightly from 2.6 percent in 2015 to an estimated 2 percent in 2016 (Figure 1). Tourist inflows were steady, with stay-over arrivals growing by 3 percent, mostly from the U.S., while visitors from the U.K. continued to decline (Figure 2). Nonetheless, despite higher arrivals, tourism receipts were virtually flat (Table 6). The inflow of revenues from Citizenship-By-Investment (CBI) programs decelerated, weakening construction activity in St. Kitts and Nevis and, to a lesser extent, in Antigua and Barbuda. Declining commodity and food prices and a negative output gap continued to exercise downward pressure on inflation.
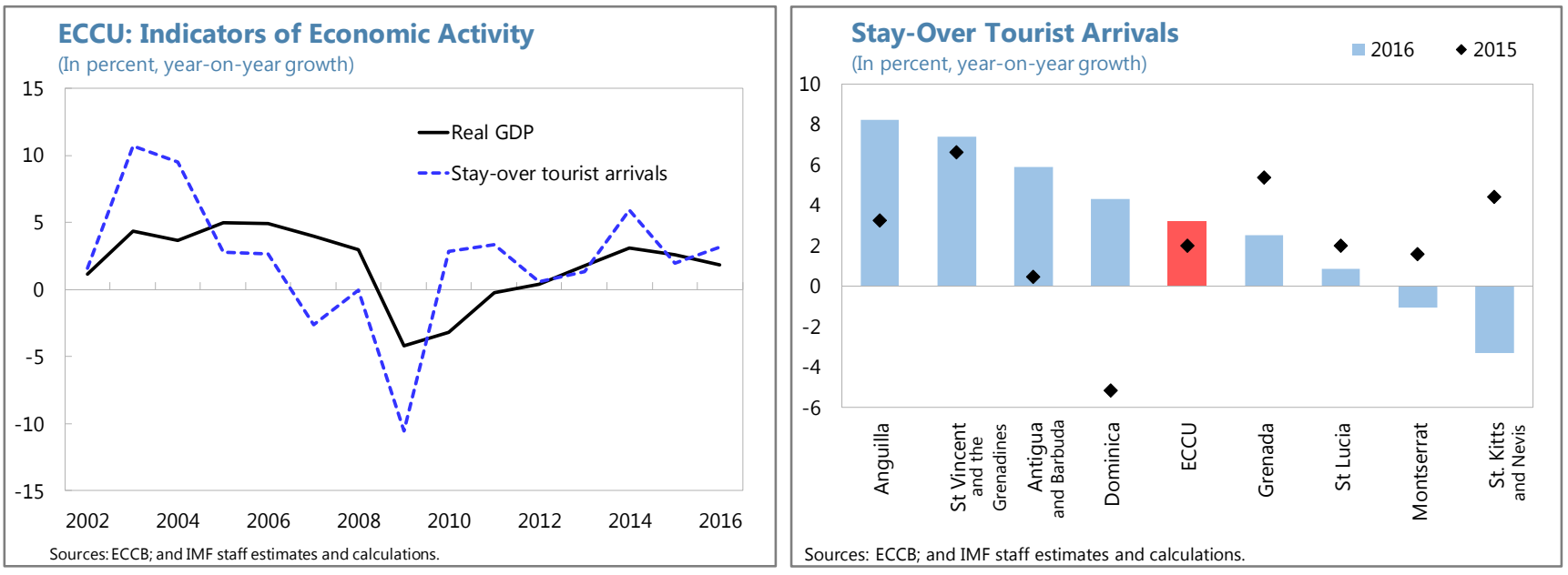

2. Fiscal receipts from CBI programs declined. While the number of applications has been stable, increased competition among countries is reducing requirements, which lower revenue per citizenship, and an increasing share of receipts are not recorded on budget. Revenue in St. Kitts and Nevis dropped sharply after its 2014 peak (Annex II). Increased competition and intensified due diligence of prospective applicants impacted income in Antigua and Barbuda. Conversely, Dominica's lower cost and more aggressive marketing approach has contributed to increase its regional market share. St. Lucia, after a disappointing launch in 2016, made its program more competitive.

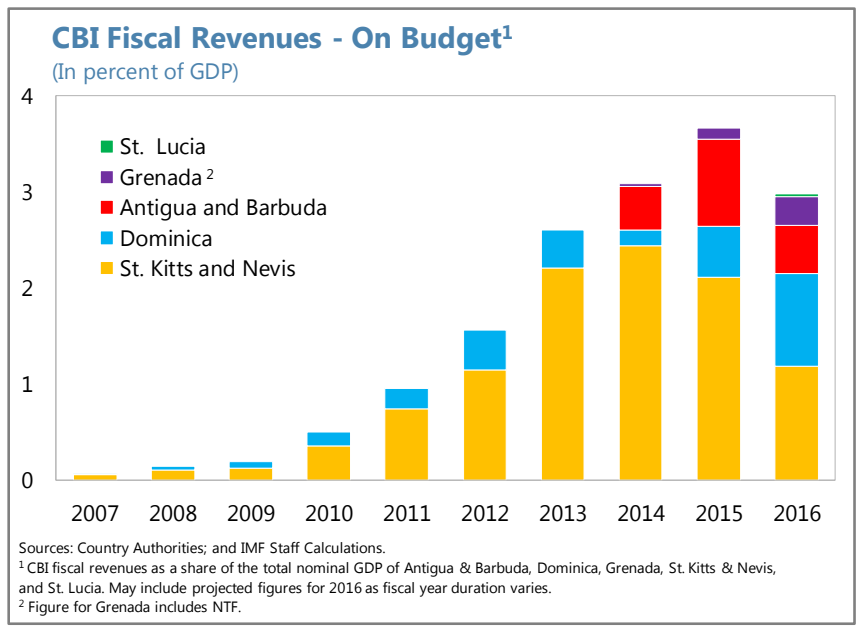


3. External conditions were broadly stable in 2016. The regional current account deficit is estimated to have worsened from 10 percent of GDP in 2015 to about 11.9 percent of GDP in $2016 .{ }^{1}$ This deterioration resulted from repatriation of hotel profits and lower exports of goods, which declined by about 12 percent, largely reflecting oneoff factors in St. Lucia and Dominica. The deficit continues to be financed mostly through FDI inflows, which -at 12.1percent of GDP - are largely aligned with the average of 12 percent of GDP over the last 20 years. International reserves rose by 8.3 percent to almost $\$ 1.7$ billion, equivalent to 6.5 months of current year imports of goods and

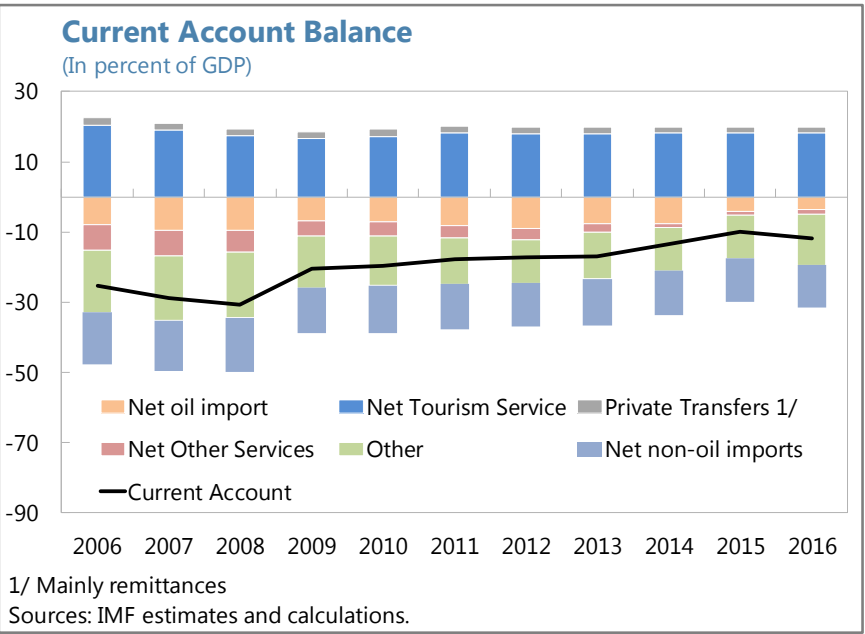
services.

4. The fiscal position weakened and public debt remains high. The regional fiscal deficit of central governments rose from 0.7 percent of GDP in 2015 to 1.9 percent of GDP in 2016. This reflected the costs of bank resolution in Anguilla; declining receipts from the citizenship program in St. Kitts and Nevis; reconstruction expenditure in Dominica following tropical storm Erika; and fiscal policy easing in St. Lucia. Improvements in other countries reflected previous costs of bank resolution (Antigua and Barbuda); fiscal consolidation (Grenada); and financing constraints (St. Vincent and the Grenadines). Increasing financing pressures, evidenced by deposit drawdowns in Antigua and Barbuda and capital spending compression in St.

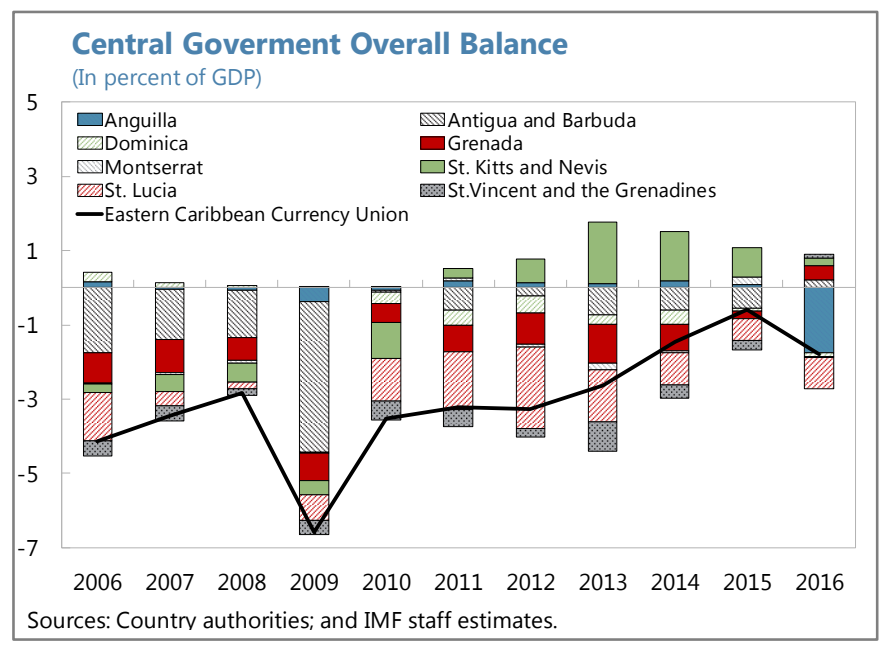
Vincent and the Grenadines, further highlight the need for fiscal adjustment. Public sector debt declined marginally from 81 percent of GDP in 2015 to 79.8 percent of GDP in 2016, remaining well above the 2030 regional target of 60 percent of GDP.

\footnotetext{
${ }^{1}$ Based on BPM5 methodology. BPM6-based statistics, which the ECCB is expected to release soon for 2014 and 2015, are likely to present smaller external deficits throughout the region, mainly on account on new improved surveys for selected items, including tourism. Preliminary estimates for 2014 released in 2015 show a current account deficit on average 10 percentage points of GDP lower than in previous BPM5-based estimates.
} 
5. Persistent weaknesses restrain bank lending. NPLs remain high at 15.1 percent of total loans for indigenous banks and 9.2 percent for foreign banks. Bank's efforts to strengthen their balance sheets are often frustrated by debtor-friendly foreclosure laws, while near-zero profitability restricts banks' ability to raise provisioning, which remains low at 46 percent of NPLs. Accordingly, banks have been unwilling to expand credit to the private sector, which fell by 5.9 percent year-onyear in December 2016 — the fourth consecutive year of decline, dragging down growth.

\section{The withdrawal of correspondent banking relationships (CBRs) has mostly hit the offshore sector, but increasing costs have reduced profitability in indigenous banks.}

Terminations of CBRs have caused some offshore banks to lose their license, and discouraged new applications. Conversely, and unlike elsewhere in the Caribbean, onshore indigenous banks overall have not experienced any significant loss of CBRs. ${ }^{2}$ Due diligence costs and fees charged by correspondent banks have increased, but only partly passed onto customers, thereby reducing already low profitability. Moreover, clients considered risky, including money business services, were denied CBR services. Trade finance has been restricted in some countries and check clearing, particularly Eurocheque services, was discontinued in some cases due to increased transaction costs.
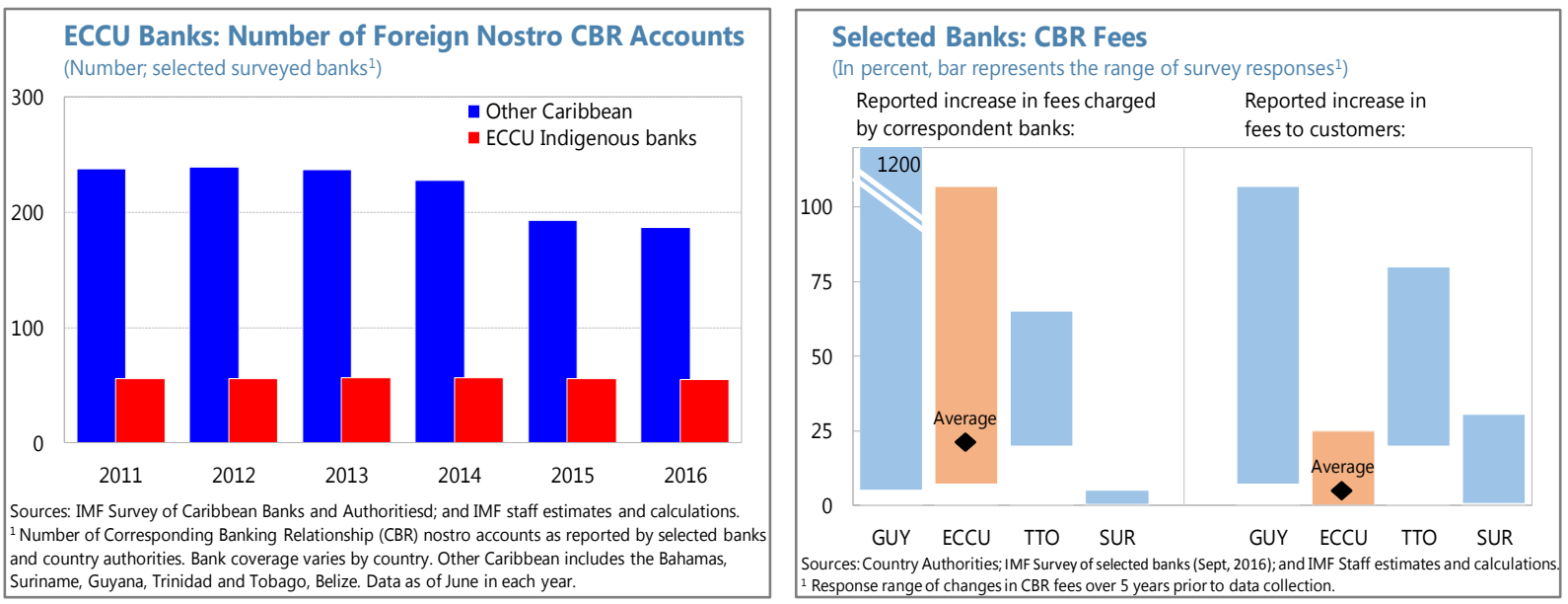

\section{OUTLOOK AND RISKS}

7. Growth is expected to rise to $2 \frac{1}{2}$ percent in the near term before converging to its potential at around 2 percent. Regional prospects have improved since the last decade, given a broadly positive external environment, significant CBI inflows, and the resolution of the intervened banks in Antigua and Barbuda and Anguilla. The expected improvement in growth is underpinned by a recovery in tourism, and sizable investment projects in public infrastructure and in the tourism industry. Over the longer term, staff estimates indicate that, without a significant change in policies, potential growth in the region will remain low, in the range of 1.5-2.5 percent. These estimates are

\footnotetext{
2 The results of a survey of Caribbean banks conducted by the IMF in September 2016 indicate that the few indigenous banks that lost CBRs in the ECCU were able either to find replacements or to continue with no significant consequences with fewer correspondent banks.
} 
based on historical trends in employment and accumulation of physical and human capital, and account for the impact of natural disasters (Box 1).

8. Risks to the baseline are broadly balanced. The rebalancing of the U.S. policy mix is likely to entail spillovers to the ECCU, but the net effect is uncertain, with an upside risk from an expansionary U.S. fiscal policy at least partly offset by the risk of a stronger U.S. dollar, lowering ECCU competitiveness, and higher interest rates. Tighter U.S. immigration policy may increase the demand for CBI programs, which however may fall if host countries reduce visa-free access to CBI passport holders. Lack of progress on reducing public debt, strengthening the banking sector, and boosting productivity could undermine confidence and hold back growth. Recurrent natural disasters present a major risk for ECCU countries (Box 2). 


\section{Box 1. Potential Growth1/}

In the last decade, growth in the ECCU has been historically low and well below that of the rest of the world. This is explained by developments affecting the accumulation and utilization of all factors of production, and by productivity trends. Labor was affected by out-migration, especially of skilled workers. Physical capital accumulation was hampered by natural disasters - a trend that could worsen over time with climate change-, financial sector weaknesses, and high public debt.

Staff estimates based on a growth accounting framework highlight the role of productivity. These estimates - which account for the impact of natural disasters on physical capital and of migration on labor and human capital - show that total factor productivity was negative in the last decade, with important differences across countries. Without stronger policies to enhance the business environment and the functioning of labor markets, annual potential growth can be expected to be in the 1.5-2.5 percent range for the region.

\section{Determinants of growth in the ECCU}

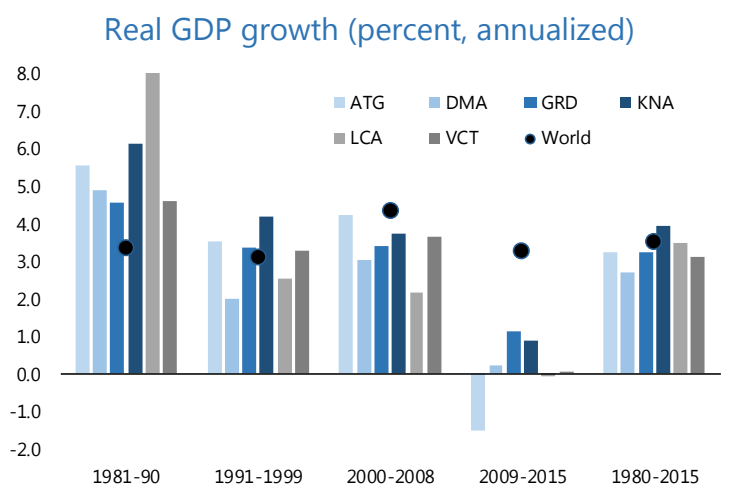

Annualized Growth of Total Factor Productivity (yoy, percent change)

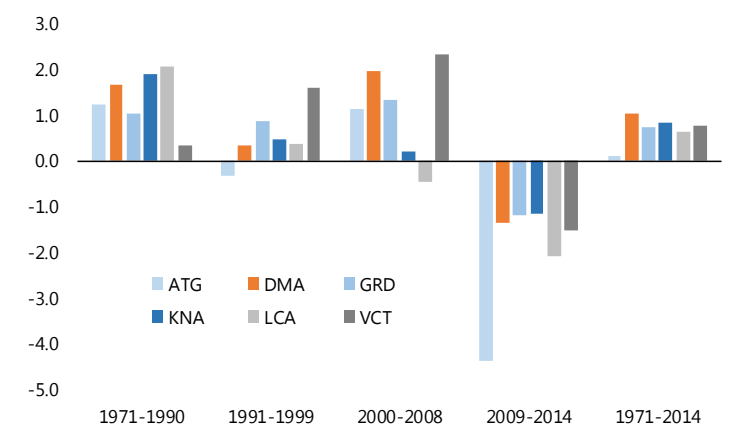

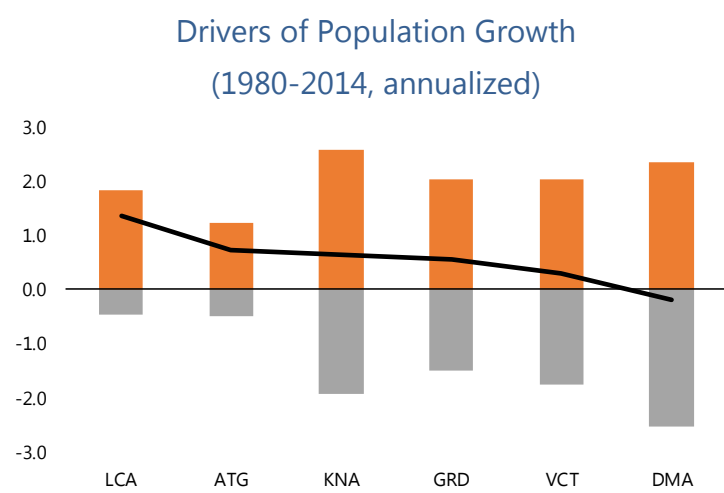

Natural growth rate Impact of migration - Population growth

Potential Output Growth ${ }^{2 /}$

(yoy, percent change)

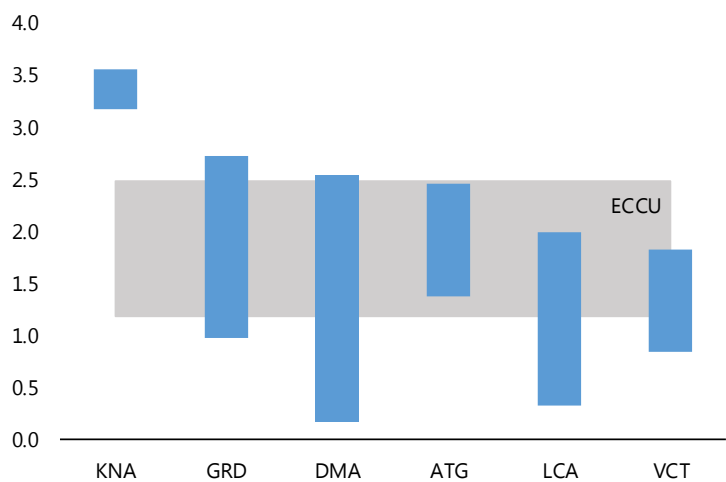

$1 \backslash$ Based on Conto, B. and A. Guerson" Productivity and Growth in the ECCU", Selected Issues Paper, forthcoming

$2 \backslash$ Ranges indicate potential growth under alternative assumptions on the evolution of the factors of production based on trends observed in alternative historical periods. 
Box 2. Risk Assessment Matrix (RAM) ${ }^{1}$

\begin{tabular}{|c|c|c|c|}
\hline Nature/Source of Main Risks & $\begin{array}{l}\text { Relative } \\
\text { Likelihood }\end{array}$ & Expected Impact & Recommended Policy Response \\
\hline \multirow[b]{2}{*}{$\begin{array}{l}\text { Policy and geopolitical } \\
\text { uncertainties }(\downarrow \uparrow) \text { Two-sided risks } \\
\text { to U.S. growth with uncertain } \\
\text { policies and global spillovers. Harder } \\
\text { line on U.S. immigration policy may } \\
\text { increase demand for citizenship } \\
\text { programs in the short term, but } \\
\text { could reduce it in the longer term. } \\
\text { Reduced international cooperation } \\
\text { on climate change. }\end{array}$} & \multirow[t]{2}{*}{ High } & High & \multirow[b]{2}{*}{$\begin{array}{l}\text { Diversify export and tourism markets. } \\
\text { Use CBI revenues and elevated } \\
\text { deposits to reduce debt, build buffers, } \\
\text { and finance priority projects in } \\
\text { disaster-resilient infrastructure projects. } \\
\text { Strengthen due diligence and oversight } \\
\text { of CBI programs to reduce financial } \\
\text { integrity and international security } \\
\text { risks. Improve the prioritization of } \\
\text { government spending. }\end{array}$} \\
\hline & & $\begin{array}{l}\text { Higher (lower) U.S. growth } \\
\text { could stimulate (depress) } \\
\text { tourism to ECCU countries } \\
\text { and boost (lower) their } \\
\text { growth. Lower demand for } \\
\text { CBI programs and lower CBI } \\
\text { inflows. Lower availability of } \\
\text { climate finance. }\end{array}$ & \\
\hline \multirow{2}{*}{$\begin{array}{l}\text { Further strengthening of the US } \\
\text { dollar and/or higher rates }(\downarrow) \text { Fed } \\
\text { normalization may lead to } \\
\text { appreciation and tighter financial } \\
\text { conditions globally. }\end{array}$} & \multirow[t]{2}{*}{ High } & Medium to High & \multirow{2}{*}{$\begin{array}{l}\text { Buttress competitiveness by } \\
\text { implementing structural reforms which } \\
\text { improve the business environment, } \\
\text { including the implementation of } \\
\text { standards and training staff in the } \\
\text { hospitality sector. Contain labor and } \\
\text { energy costs, and reduce public debt } \\
\text { through fiscal consolidation. }\end{array}$} \\
\hline & & $\begin{array}{l}\text { Reduce ECCU } \\
\text { competitiveness on non-US } \\
\text { markets and raise the cost of } \\
\text { servicing debt for highly } \\
\text { indebted ECCU countries. }\end{array}$ & \\
\hline $\begin{array}{l}\text { Reduced financial services by } \\
\text { correspondent banks }(\downarrow) \\
\text { Significant curtailment of cross- } \\
\text { border financial services in emerging } \\
\text { and developing economies. }\end{array}$ & High & $\begin{array}{l}\text { High } \\
\text { Further rise in banks' cost of } \\
\text { processing international } \\
\text { transactions, with at least } \\
\text { some economic disruptions } \\
\text { in some countries. }\end{array}$ & $\begin{array}{l}\text { Continue to strengthen AML/CFT and } \\
\text { international tax cooperation } \\
\text { frameworks; promote bank } \\
\text { consolidation; further enhance } \\
\text { transparency in CBIs. Explore } \\
\text { alternative options to existing } \\
\text { arrangements for correspondent } \\
\text { banking services. }\end{array}$ \\
\hline $\begin{array}{l}\text { Deterioration in the terms or level } \\
\text { of PetroCaribe's financing }\end{array}$ & High & $\begin{array}{l}\text { High } \\
\text { Government and BoP } \\
\text { financing would be curtailed. }\end{array}$ & $\begin{array}{l}\text { Prepare contingent sources of } \\
\text { financing in case the agreement ends } \\
\text { abruptly. Manage PetroCaribe flows } \\
\text { prudently. }\end{array}$ \\
\hline $\begin{array}{l}\text { Lack of progress in implementing } \\
\text { domestic policies }(\downarrow)\end{array}$ & Medium & $\begin{array}{l}\text { High } \\
\text { Confidence could be } \\
\text { undermined and growth } \\
\text { suffer. }\end{array}$ & Stepping up policy implementation. \\
\hline \multirow{2}{*}{$\begin{array}{l}\text { Larger and more frequent natural } \\
\text { disasters }(\downarrow) \text { Hurricanes and floods } \\
\text { causing increasing widespread } \\
\text { damage, destruction of physical } \\
\text { capital, and reduction in tourist } \\
\text { arrivals. }\end{array}$} & \multirow[t]{2}{*}{ Medium } & High & \multirow{2}{*}{$\begin{array}{l}\text { Build a consistent framework with } \\
\text { investment in resilience and } \\
\text { appropriate ex ante financing, } \\
\text { including fiscal buffers. }\end{array}$} \\
\hline & & $\begin{array}{l}\text { Negative impact on growth, } \\
\text { increased debt. }\end{array}$ & \\
\hline \multirow[t]{2}{*}{ Spread of Zika virus $(\downarrow)$} & \multirow[t]{2}{*}{ Medium } & Medium & \multirow{2}{*}{$\begin{array}{l}\text { Further enhance eradication and } \\
\text { protection actions; implement public } \\
\text { education campaign. }\end{array}$} \\
\hline & & $\begin{array}{l}\text { Would reduce tourism and } \\
\text { growth. }\end{array}$ & \\
\hline \multicolumn{4}{|c|}{$\begin{array}{l}\text { 1/ The Risk Assessment Matrix (RAM) shows events that could materially alter the baseline path (the scenario most likely to } \\
\text { materialize in the view of IMF staff). The relative likelihood is the staff's subjective assessment of the risks surrounding the } \\
\text { baseline ("low" is meant to indicate a probability below } 10 \text { percent, "medium" a probability between } 10 \text { and } 30 \text { percent, and } \\
\text { "high" a probability between } 30 \text { and } 50 \text { percent). The RAM reflects staff views on the source of risks and overall level of } \\
\text { concern as of the time of discussions with the authorities. Non-mutually exclusive risks may interact and materialize jointly. } \\
\text { "Short term" and "medium term" are meant to indicate that the risk could materialize within } 1 \text { year and } 3 \text { years, respectively. }\end{array}$} \\
\hline
\end{tabular}




\section{POLICY DISCUSSIONS}

The currency union is providing a strong anchor for macroeconomic stability and low inflation in a region highly exposed to external shocks and natural disasters. Continued success depends on its ability to reduce high public debt, strengthen resilience to shocks, address financial sector weaknesses, and boost productivity and competitiveness. Discussions focused on policies to achieve these objectives in the context of greater policy coordination and deeper economic integration.

\section{A. Strengthening the Fiscal Policy Framework to Address Sustainability Challenges}

\section{Policy responses to the global financial crisis have increased rigidities in government} budgets which will be best addressed by medium-term structural reforms. Wage bills absorb a large share of budgetary resources, which has increased in most countries over the last decade. Moreover, public pension increments are often linked to wage increases, magnifying their impact on government spending. Reversing this trend will require well-designed programs to reform institutions and policies and improve the framework for wage negotiations, the composition and distribution of government, addressing shortages and overstaffing. Adequate social safety nets will also be needed to de-link public employment

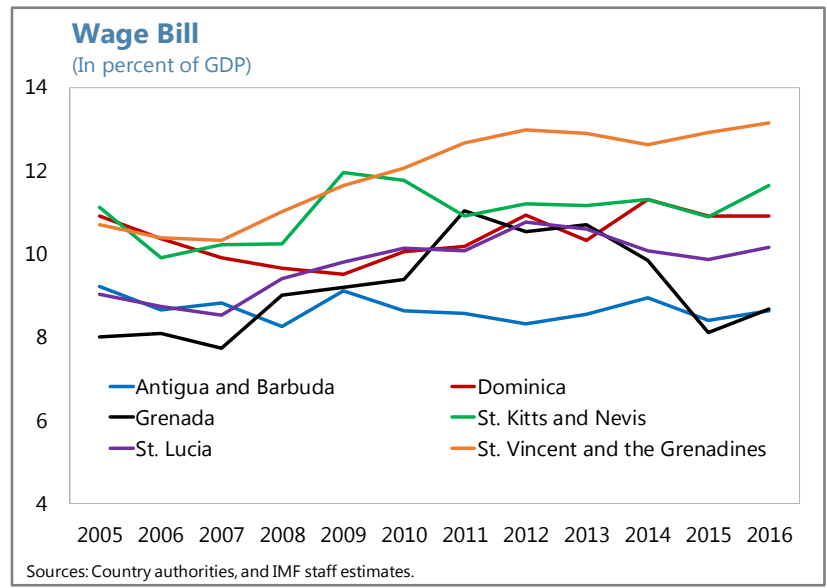
policies from social welfare objectives. Dominica, Antigua and Barbuda, St. Kitts and Nevis are taking steps in this direction while Grenada has developed a public service management reform strategy to be implemented over 2017-2019 (Annex III).

\section{ECCU member countries need a significant fiscal effort to achieve their debt target.}

ECCU governments set a public debt target of 60 percent of GDP by 2030, but fiscal policies in member countries are not explicitly designed to achieve this commitment. On current policies (passive scenario), or even in a more realistic scenario where current policies cannot be fully financed (baseline scenario), the region is not expected to reach its debt target by 2030. Where possible, large deposits from CBI inflows should be used to reduce debt. The adoption of appropriately designed fiscal rules would provide governments with a

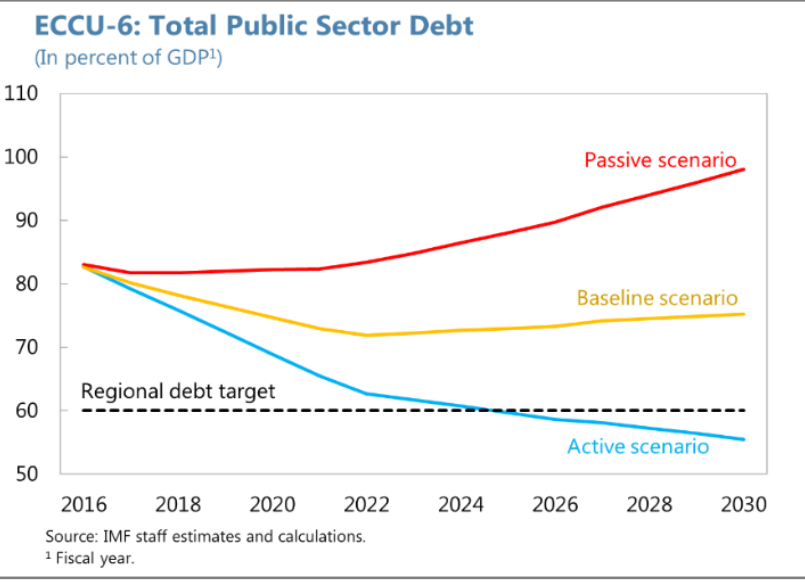
commitment device to anchor their fiscal adjustment strategies (active scenario) to the debt target, 
and safeguard them from pressures to deviate from that path (Box 3).3 This effort could build on reforms already under way to adopt or refine medium-term fiscal frameworks and strengthen public financial management, including in the design and implementation of public investment programs (Annex IV).

\section{Fiscal rules should be flexible, but ought not substitute for sound preparation for}

natural disasters. In the case of large scale natural disasters, escape clauses can be considered to allow governments the ability to respond quickly and adequately. Meanwhile, governments should shift their focus from disaster response to disaster preparation. Domestic policies to address natural disasters should be strengthened and integrated into investment, debt, and public financial management frameworks. Countries should assess risks from natural disasters, including to financial stability, and adopt adequate crisis management frameworks. Disaster financing should be arranged before the event through a combination of fiscal buffers, contingent financing plans, and risk transfer arrangements. The medium-term fiscal framework should fully internalize the estimated fiscal costs of natural disasters. In this context, the need for an escape clause would be limited to exceptional disasters.

\section{ECCU countries are looking at ways to strengthen regional collaboration on CBI} programs. These programs present fiscal, macroeconomic, and reputational externalities that require careful management. ECCU authorities have asked the Organization of Eastern Caribbean States (OECS) Commission to provide a framework to readjust, reposition, and recalibrate individual CBI programs, including in representing these programs to the rest of the world. A regional approach would have several advantages, including: (i) reducing costs as economies of scale could result from concentrating certain functions, such as background checks; (ii) increasing revenues by preventing a "race to the bottom" that lower conditions for citizenships; and (iii) reducing reputational risks by centralizing safeguards and eliminating incentives to reduce governance standards

\footnotetext{
${ }^{3}$ The only two Caribbean countries (Jamaica in 2014 and Grenada in 2015) that have adopted fiscal responsibility laws did so while undertaking fiscal adjustment supported by IMF programs and hence benefited from a commitment strategy. Anguilla's Fiscal Responsibility Act also includes ceilings for net debt contracted and debt service (80 percent and 10 percent of recurrent revenue, respectively).
} 


\section{Box 3. Fiscal Rules ${ }^{1 /}$}

The ECCU debt target is not accompanied by a policy coordination mechanism to meet the target. The ECCU has set a target for member countries' public debt of 60 percent of GDP by 2030 . However, attaining this target requires a framework to provide short-term operational guidance, including outlining the target's path and ensuring adherence to it.

Setting fiscal rules and sound foundations for their effective implementation would help countries achieve the debt target. Some ECCU countries are preparing or refining their medium-term fiscal frameworks and reforming their public financial management. Building on these reforms, implementing fiscal rules would provide governments with a pre-commitment strategy to help them pursue sustainable fiscal policies, despite political economy pressures to deviate from that path.

Empirical evidence shows that countries with well-designed fiscal rules (such as budget balance and debt rules) are associated with stronger fiscal performance. ${ }^{2}$ Moreover, countries with more binding fiscal rules tend to run larger primary balances than countries without fiscal rules. ${ }^{3}$ Furthermore, more recent evidence for advanced economies indicates that, even in countries with a mixed record of fiscal responsibility, fiscal rules can lower financing costs. ${ }^{4}$

Laws already adopted in Jamaica and Grenada provide useful benchmarks for designing fiscal rules in ECCU countries. ${ }^{5}$ Both countries designed their fiscal rules to reflect best practices and each country's specific circumstances. Both sets of rules feature: (i) a ceiling on the wage bill; (ii) a primary surplus floor; (iii) a public debt ceiling; (iv) automatic correction mechanisms for deviations from the rule; (v) escape clauses; and (vi) an institution responsible for monitoring and reporting to parliament on the consistency of fiscal developments with the rule, like the fiscal councils adopted in many countries. Anguilla's Fiscal Responsibility Act also is an interesting case of legislation setting borrowing limits.

Fiscal rules for ECCU countries should be easily monitored and communicated, exclude exceptional nontax revenue, recognize the recurrence of natural disasters, and be supported by strong PFM and statistical reporting. The selected operational target should be the primary balance floor, as it is fully controlled by each country's government, is simple to understand, leads to a lasting reduction in public debt, and is verifiable. The definition of government should cover statutory bodies and government enterprises. The primary balance rule should exclude most exceptional non-tax revenue such as receipts from CBI programs. To preserve its credibility, the fiscal rule needs to include escape clauses allowing the government to temporarily deviate from the rule under very specific circumstances and a procedure for returning to the rule. Effective public finance management (PFM), credible medium-term fiscal plans, and adequate statistics, including from public enterprises, are necessary preconditions for the implementation of fiscal rules. The task of monitoring the government's implementation of the fiscal rule and reporting it to the public should be performed by an independent institution with sufficient technical capacity.

\footnotetext{
1/ Based on G. Impavido and D. Simard "Fiscal Rules for the ECCU", Selected Issues Paper, forthcoming

2/ Schaechter et al. (2012), "Fiscal Rules in Response to the Crisis. Toward the "Next

Generation" Rules", IMF Working Paper 12/187.

3/ International Monetary Fund (2013), "The Functions and Impact of Fiscal Councils", IMF Policy Paper, November.

4/ International Monetary Fund, April 2017 Fiscal Monitor, chapter 1, "Achieving More with Less".

5/ Jamaica, IMF country report No. 14/169, p. 13 and pp. 67-68, and Grenada, IMF country report No. 15/193, Annex IV.
} 


\section{The Authorities' View}

13. ECCU countries intend to focus on forward-looking fiscal policies to attain their $\mathbf{2 0 3 0}$ debt target. In the July session of the ECCB's Monetary Council, member countries will discuss interim targets for 2020 and 2025, which are expected to be underpinned by well-articulated fiscal frameworks. Most member countries appreciate the importance of adopting fiscal responsibility legislation to support the adjustment effort and create additional fiscal space. The ECCB stands ready to provide member countries with technical support. The ECCB agrees on the importance of containing the wage bill and some national government are preparing reform plans.

14. Fiscal buffers are needed to address recurrent natural disasters, but may be difficult to build in some countries. The ECCB reiterated that member countries should allocate some resources from CBI programs to a fund covering the fiscal cost of natural disasters as they arise and to finance investment in climate resilient infrastructure. It acknowledged, however, that building adequate buffers might strain countries that cannot count on significant CBI resources or are confronted by immediate fiscal challenges.

\section{B. Strengthening the Financial Sector}

\section{Finalizing the regional strategy to strengthen the banking sector is key to enhance} financial sector stability and for banks to resume lending. Completing the final steps to establish the ECAMC will allow the collection under one roof of distressed assets under receivership, providing a vehicle for the disposal of banks' bad assets. Meanwhile, easing restrictions on noncitizen property ownership would support the sale of collateral while a new macro-prudential framework would provide additional tools to the ECCB. ${ }^{4}$ Modernizing the foreclosure and insolvency framework is also necessary to maximize the recovery of bad assets, minimize fiscal costs, and improve bank resolution in future crises. New harmonized collateral appraisal guidelines developed with Fund TA and new provisioning regulations will improve the quality of credit decisions and reduce losses from NPLs. Bank consolidation can address capital needs in some cases. Moreover, staff analysis indicates that it could help enhance the efficiency and resilience of the banking system (Box 4).

\footnotetext{
${ }^{4}$ CARTAC is expected to provide technical assistance in selecting instruments and preparing key inputs, like a real estate price index.
} 


\section{Box 4. The Consolidation of Indigenous Banks}

ECCU banks with relatively high NPLs show higher loan portfolio concentration, both across economic sectors and countries. Staff simulations indicate that the consolidation of existing indigenous banks could strengthen capital positions and increase financial stability. These simulations also show that consolidation can enhance banks' resilience to shocks by increasing portfolio diversification across sectors and countries. To some extent, these gains can be achieved with a limited impact on the market power of the amalgamated institutions, but the ECCB should monitor carefully the risk of a large bank becoming too big to fail, which could undermine the stability of the currency union.

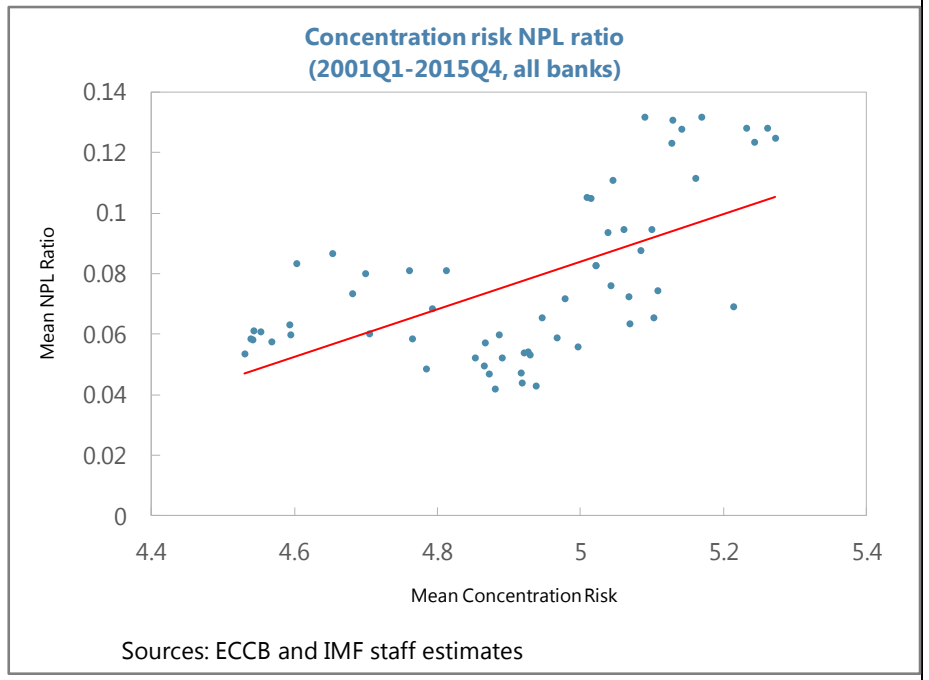

As the number of amalgamated banks increases, loan concentration risk falls and the likelihood of bank failure (measured by an increasing Z-score) also declines...

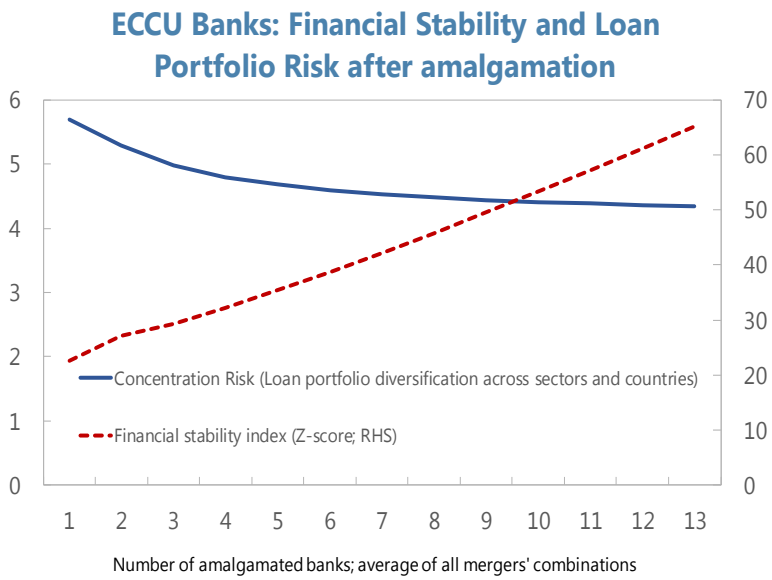

Sources: ECCB and IMF staff estimates. ...while market concentration rises only slowly, suggesting that a trade-off between financial stability and competition would arise only at high levels of concentration

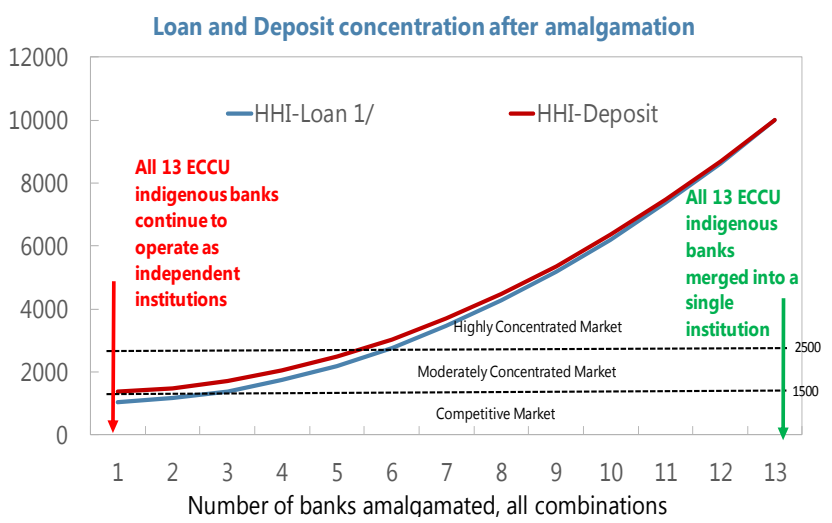

$1 /$ The Herfindahl-Hirschman index $(\mathrm{HHI})$ is a measure of market concentration. It is calculated by squaring the market share of each firm competing in a market, and then summing the resulting numbers. It can range from close to zero (highly competitive market) to 10,000 (Highly concentrated market). HHI-Loan is calculated by share of loan size, HHI-Deposit is calculated by share of deposit size.

\section{Operations of the Regional Government Securities' Market (RGSM) can be improved} to increase financial deepening and support fiscal consolidation. Member governments spend on average 3 percent of GDP in interest, reflecting high public debt and servicing costs. Lack of depth, low competition, limited information, and inefficient auction operations contribute to increasing reliance on over-the-counter issuance and limiting the development of the RGSM, both in volumes and yield reduction. Moreover, these shortcomings prevent the development of a secondary market, which is key to ensure effective functioning of a competitive primary market. 
Improving the efficiency of the RGSM and a more active debt issuance policy by governments could yield valuable savings, supporting the fiscal adjustment effort needed to achieve their $2030 \mathrm{debt}$ target (Annex V).

17. The minimum saving rate (MSR) distorts credit markets and contributes to increasing the cost of government financing. The MSR has several drawbacks, including its impact on public debt service. ${ }^{5}$ By setting a floor to the remuneration of excess liquidity, it raises the interest rate on government securities when markets are very liquid and discourages the development of a secondary market. Evidence shows that the MSR significantly impacts credit markets. ${ }^{6}$

\section{Full compliance with international AML/CFT standards, stronger regulatory and} supervisory frameworks, and bank consolidation would reduce the risk of further withdrawal of CBRs. The authorities have made significant efforts to ensure compliance with international AML/CFT standards. Consolidation of AML/CFT supervision with the ECCB and harmonization of AML/CFT legislations are welcome. However, more progress is needed to comply with the 2012 FATF and tax transparency standards. Implementation by all banks of the Basel Capital Accord based on updated asset quality assessments and of risk-based supervision in bank and non-bank financial sectors would improve perceptions held by international banks. Another important step is improving communication and information sharing between respondent and correspondent banks, while bundling correspondent banking services with other products can generate economies of scale and lower fixed compliance costs. Lastly, bank consolidation could lower compliance costs, promote sharing of best practices, and generate sufficient volumes and profitable traffic for large foreign correspondent banks.

\section{Gaps in the regulatory framework for credit unions are a source of concern. Credit} unions are a significant component of the financial sector in some ECCU countries -especially St. Vincent and the Grenadines, Dominica, and St. Lucia- and have grown elsewhere. The sector, however, is affected by weak regulatory standards, insufficient enforcement, and low profitability. Regulation and supervision in each country rest under the responsibility of local regulatory authorities, which are constrained by insufficient resources and weak enforcement powers.

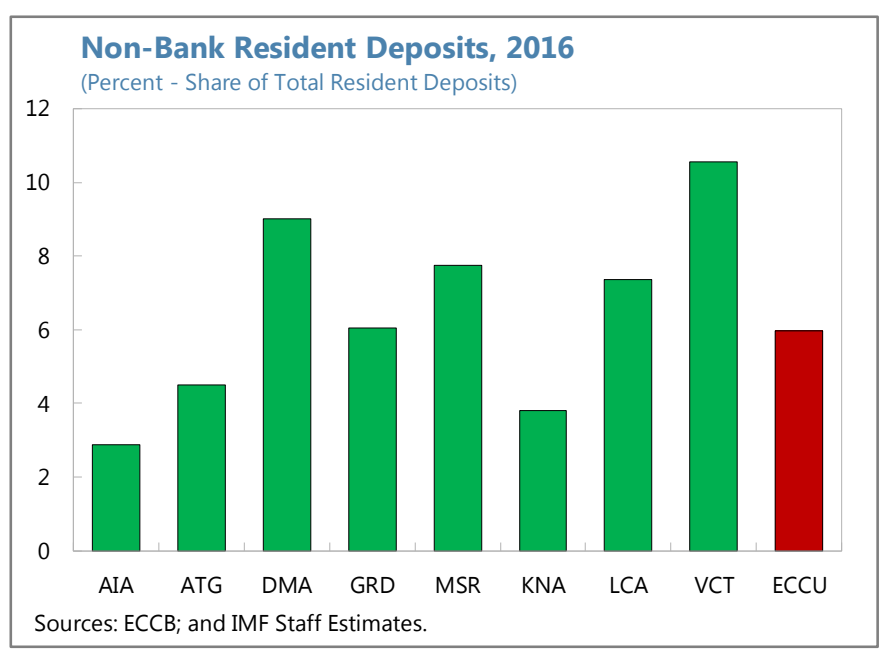

\footnotetext{
${ }^{5}$ The MSR was extensively covered in last year's discussion on ECCU common policies (Country Report No. 16/333).

${ }^{6}$ The 2015 reduction of the MSR has been passed on fully to deposit rates (Figure 3). The partial transmission to observed lending rates, which are measured relative to the stock of bank credit, could be explained by the limited flow of new lending and banks' using higher profits to clean up balance sheets.
} 
Strengthening the regulatory framework is particularly important given the close links between credit unions and the banking sector, mainly through deposits.

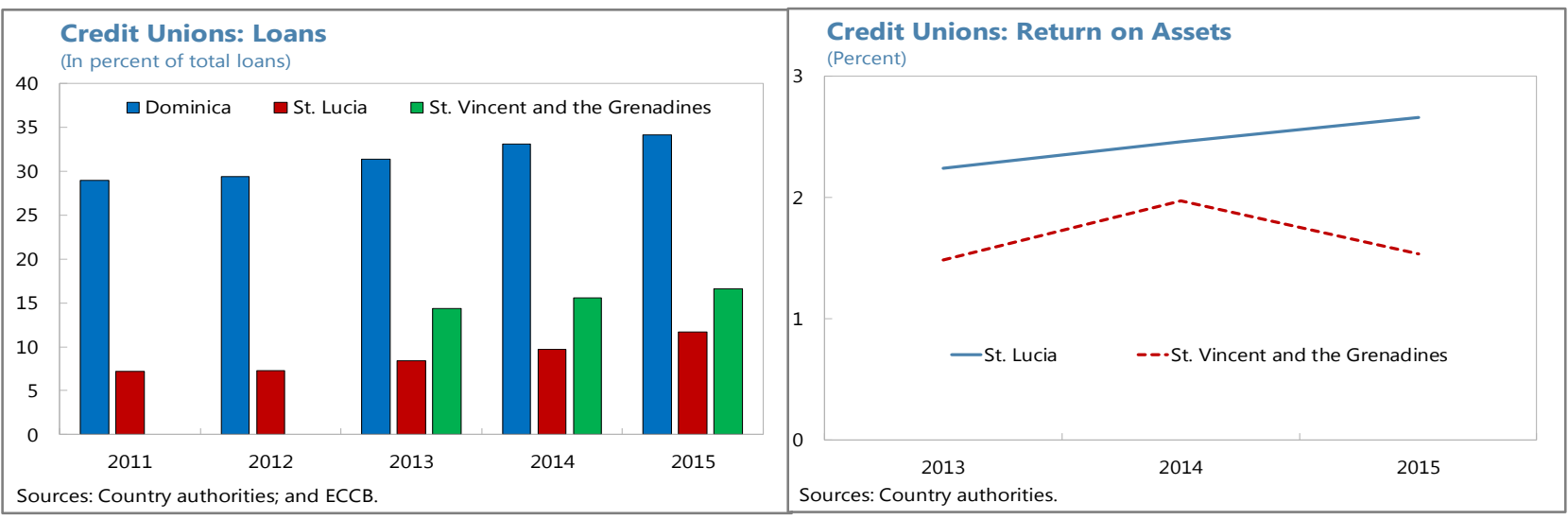

20. The authorities are strengthening the regulatory framework for credit unions. Draft harmonized legislation on credit unions, currently under review by local regulators, includes specific penalties for noncompliance; the requirement of annual license registration; a maximum of three years to comply with minimum capital requirements. It also includes: (i) a cap on mortgage loans of 45 percent of total loans; (ii) allowing membership of credit unions to companies, as opposed to natural persons only; (iii) a minimum capital contribution to serve as a volunteer, applicable to Board members; (iv) a minimum threshold of shared capital of 20 percent of total capital; and ( $v$ ) fit-andproper requirements on management, including minimum education requirements for Board members, and a cap on the number of volunteers and immediate family members. The harmonized legislation on credit unions may provide a first step towards future unification of credit union regulation.

\section{The $\mathbf{2 0 1 6}$ update safeguards assessment found that the ECCB continues to maintain a} governance framework that provides for independent oversight. Transparency in financial reporting has been maintained and the external audit mechanism is sound. The ECCB is taking steps to restructure the internal audit and risk management functions to align them with leading international practices.

\section{The Authorities' View}

22. The ECCB underscored progress in strengthening the financial sector. It noted that intensified on-site supervision supported stronger regulatory enforcement and the identification of emerging capital needs. The ECCB further noted that all banks now comply with minimum capital adequacy ratios, and are expected to conform with the minimum capital requirement within the 450-day deadline established by the new Banking Act. The authorities agreed on the importance of the timely transfer of receiverships to the ECAMC. The authorities expect the ECAMC to be fully operational soon. Efforts are ongoing towards fully implementing a consolidated supervisory framework. Fund and World Bank technical assistance has been deployed in 2016 and 2017 to improve credit unions' data reporting quality and consistency, and to develop stress testing capacity 
among local regulators and supervisors. The ECCB is also developing its own capacity to monitor developments in credit unions and mitigate related risks for banks.

\section{AML/CFT supervision was strengthened, but maintaining CBRs is challenging. The} authorities noted the recent decision by the Monetary Council for the ECCB to assume responsibility for AML/CFT regulation of all institutions licensed under the Banking Act. Risks to CBRs are mostly related to the small scale of business of respondent banks relative to the high penalties imposed by foreign regulators on correspondent banks, which in some cases make CBRs unprofitable, and bank consolidation may contribute to alleviate this problem.

\section{The authorities maintained their reservations on the benefits of eliminating the MSR.}

They noted that lending rates declined only slightly after the recent reduction in the MSR, and the impact has been muted on credit dynamics and credit growth in general. Additional bank fees on savings accounts have reduced the effective MSR to almost zero or negative in some instances. Without saving and investment alternatives, the maintenance of the MSR is an instrument to incentivize private saving and support households' income. Future decisions regarding the minimum savings rate would be influenced by recurrent assessment of the monetary and credit conditions in the ECCU and the ongoing review of the impact of the reduction in the minimum savings rate. The authorities welcome joint research on the MSR.

\section{Enhancing Competitiveness and Boosting Potential Growth}

\section{The external position is weaker than implied by fundamentals and desirable policies.}

Despite some appreciation since mid-2014, the EC dollar has remained near its long-term average in real effective terms, in line with the de-facto peg. While the INS-based REER has appreciated by about 7.6 percent over three years to December 2016, the de-facto peg of the EC dollar to the U.S. dollar and lower inflation have contributed to maintaining the customer-based REER close to its 30-year average. Meanwhile, the competitor-based REER appreciated only by 2 percent over the last three years. Estimates of the REER misalignment show an overvaluation ranging between 2.3 percent and $21 \frac{1}{2}$ percent. Record excess liquidity, mostly held at the central bank, has boosted gross

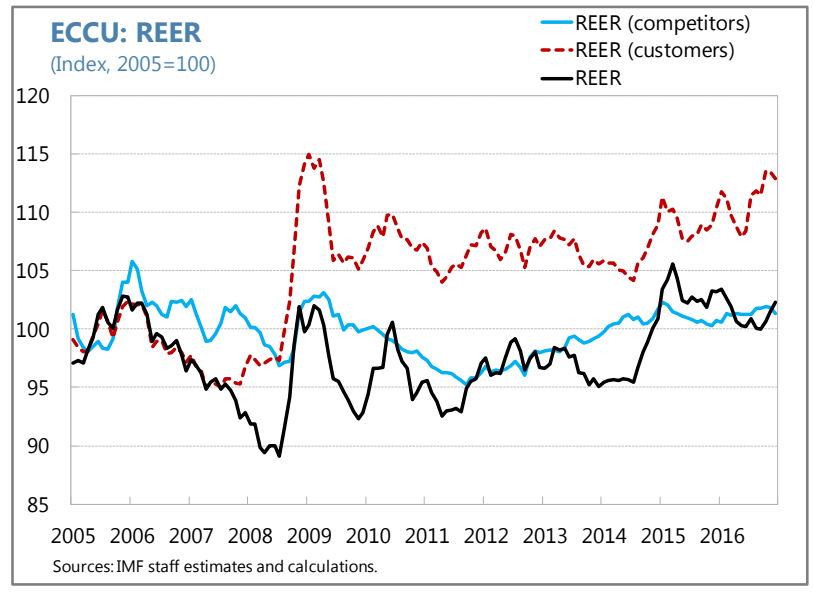
international reserves, assessed to be adequate against several benchmarks (Annex VI).

\section{Sluggish productivity is the key reason for low growth, which has become entrenched} after the global financial crisis. Moreover, investment is impacted by recurrent natural disasters, inadequate public infrastructure, financing and capacity constraints. The contribution of labor is weakened by significant outward migration, particularly of skilled workers, further reducing growth. 
Labor is concentrated in low-productivity sectors, reflecting labor market rigidities and skills mismatches (Box 1). Public employment and wage policies have contributed to labor misallocation and structural unemployment by weakening the link between wages and productivity (Annex III). ${ }^{7}$

\section{The region is highly vulnerable to natural disasters, which entail high costs. The} average annual cost of disasters for small states is almost 2 percent of GDP, over fourfold that for larger countries. For ECCU microstates, this value rises to 3.4 percent of GDP. These disasters have significant macroeconomic implications, lowering investment, increasing poverty, and reducing fiscal space. Moreover, financial and capacity constraints affect the ability of these countries to recover quickly after disasters, making their effect more permanent.

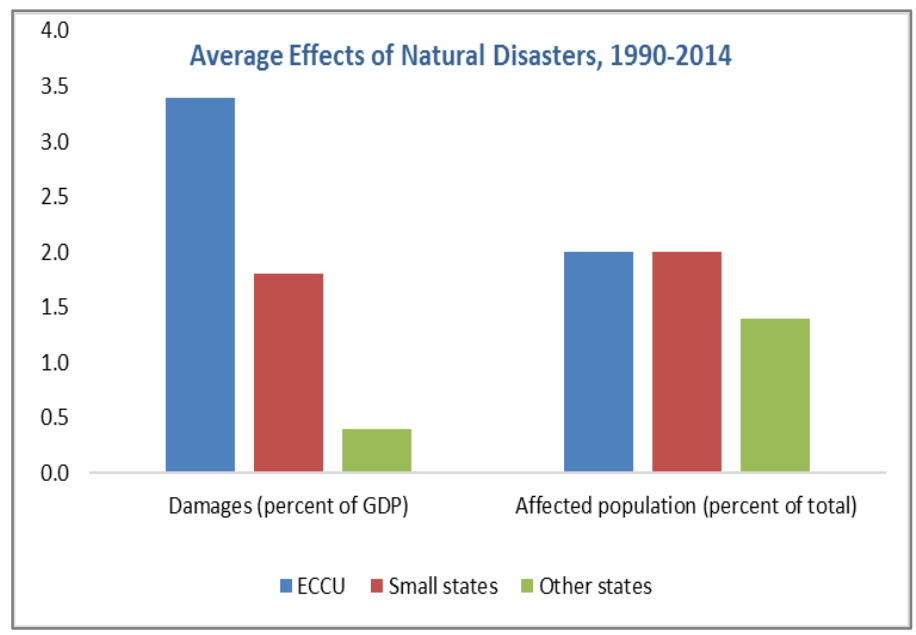

\section{The authorities are making progress on the structural reform agenda.}

- $\quad A l l$ ECCU members are rebalancing their energy mix towards renewable energy, which is essential to reduce dependence on fossil fuels and generate savings in energy costs over the long term. However, delays and regulatory impediments, including restrictions on reselling solar power back to the grid, are preventing countries from reaping all the benefits.

- Some members are strengthening their connectivity, but a coordinated approach is lacking. St. Lucia is adding new international flights, Antigua and Barbuda has completed its new airport terminal, and St. Vincent and the Grenadines has opened its new international airport. However, the cost of interisland air travel is raised by diseconomies of scale, labor rigidities, taxation and fees, and service quality is highly variable. Overall, air transport network development in the broader Caribbean reflects competition between islands for tourism, which involves distorting subsidy schemes and suboptimal routing. ${ }^{8}$

- Members are improving their tourism infrastructure by adopting development plans, strengthening regulations, and reviewing frameworks to encourage FDI in the sector. They are also developing a regional strategy for human resource development, which focuses on addressing country-specific needs in training.

\footnotetext{
${ }^{7}$ Lafeuillee, J., Li, M., James, R. Salinas, G. and Y. Savchenko, "Explaining High Unemployment in ECCU Countries". IMF Working Paper, forthcoming

${ }^{8}$ Extra-regional routes account for 82 percent of the air traffic in the region. See C. Briceño-Garmendia, H.C. Bofinger, D. Cubas, and M.F. Millán-Placci "Connectivity for Caribbean Countries", The World Bank, 2014.
} 
- Members are implementing programs to improve resilience to natural disasters and climate change Dominica is rebuilding its infrastructure strengthening resilience to climatic shocks; and St. Vincent and the Grenadines and other countries are upgrading their building codes.

- Members are also working to reduce costs of doing business and improve the business climate in several areas, with St. Lucia actively working on a program of reforms under the Caribbean Growth Forum, and Grenada and St. Vincent and the Grenadines developing on-line search facilities for deeds and property titles. Regionally, the Growth Dialogue initiative, aiming to forge consensus on the main obstacles to growth, will develop an action plan for the next two years to be implemented jointly with the OECS, ECCU governments, social and development partners.

29. Further progress hinges on improving resilience to natural disasters, enhancing public sector efficiency, and increasing regional integration. An integrated approach to risk reduction and recovery from natural disasters requires shifting from ex-post relief to ex-ante preparation (โ11). Civil service reform is also necessary to improve efficiency and quality of services, better align public sector wages with productivity, and reduce a key source of budgetary pressures. ECCU small island economies would benefit greatly from further steps to increase regional economic integration, particularly in goods and labor markets, connectivity, and financial regulation. A single jurisdiction for businesses would facilitate access to cross-border commercial opportunities and harmonized border controls would ease mobility of goods and visitors within the region and, together with enhanced inter-island connectivity, promote multi-destination tourism. Operationalizing the OECS Air Services Agreement would enable smaller airlines to field less profitable routes and concentrate service by the regional airline on key routes.

\section{The Authorities' View}

30. The authorities broadly agree with staff assessment of low external competitiveness. Improving business climate is a shared objective. Most islands are pursuing energy substitution from fossil fuels to renewables, which should lead to cost reductions in the long run. Regional authorities plan to benchmark the competitiveness of air travel in the Caribbean and assess the economic impact of connectivity, including marine transport, to further discussions in that area. Attempts are being made at reducing labor market rigidities by introducing personnel shift systems in hotels and port operations. Frictions affecting access to credit - especially foreclosure legislation and the lack of a credit registry - are being addressed at the regional level, with five countries to date agreeing to the recommendations from the report of the high-level committee established to review the land registration and foreclosure processes and procedures following a harmonized template and the establishment of a credit bureau. The decision to establish a Partial Credit Guarantee Facility jointly with the World Bank is expected to facilitate lending to SMEs.

\section{They noted that progress on economic integration will generate economies of scale} and enhance competitiveness. The draft bills on the free circulation of goods throughout the OECS are being reviewed in each member state. To boost the competitiveness of agriculture, standards for 
agriculture health and food safety are being upgraded and an initiative to ship agriculture goods is being implemented. To improve educational skills, the regional education strategy is being implemented in St. Lucia, Dominica, Grenada and St. Vincent and the Grenadines. Work is also under way to upgrade training and skills in tourism and hospitality.

\section{STAFF APPRAISAL}

32. The short-term outlook is favorable, but stronger policies are needed to break away from a low-growth trap. Growth prospects continue to be buttressed by steady demand for tourism, low oil prices, and robust FDI inflows, partly related to CBI programs. While risks to the outlook are broadly balanced, the region remains vulnerable to external shocks, policy slippages, and natural disasters. High public debt, a fragile financial system, and weak competitiveness are the main stumbling blocks on the path to higher growth. Without more decisive policies to tackle these issues, growth performance will continue to be lackluster.

33. Credible medium-term fiscal frameworks are necessary to ensure debt sustainability. The decision of the ECCB's Monetary Council to discuss interim targets towards the 2030 regional benchmark at its July 2017 meeting is a step in the right direction. The ability to adhere to mediumterm fiscal consolidation plans would be strengthened by the adoption of fiscal responsibility legislation. Grenada's Fiscal Responsibility Act, based on simple operational targets, may provide a model for other ECCU countries. Countries that have large deposits from CBI programs should use them to lower debt where possible.

34. Managing the wage bill is key to a sound fiscal consolidation strategy. Wage bills present a major budgetary rigidity, and public sector wage negotiations are often not informed by considerations of the fiscal situation and productivity. The authorities should follow a three-pronged approach based on wage moderation; employment attrition; and a functional review of the civil service. Part of the savings, which will occur gradually, could be used to build well-targeted social safety nets and reduce the need for governments to be employers of last resort.

35. Adequate preparation for natural disasters should be a top priority. The extreme vulnerability of the region to natural disasters underscores the need to enhance disaster preparedness. ECCU countries should prepare plans for investment in climate adaptation, financing, and risk management, to be fully integrated in macroeconomic and fiscal frameworks. Resilient public infrastructure should be accompanied by adequate enforcement of appropriate building and zoning codes. Mobilizing private investment and using concessional financing will be essential.

36. A formal regional framework is needed for CBI programs to strengthen their integrity, reduce risks, and preserve their capacity to generate revenue. Regional coordination would create economies of scale in due diligence on applicants, enhance transparency, and avoid a race to the bottom on programs' terms. CBI inflows should be fully recorded on budget and integrated in medium-term fiscal frameworks. CBI revenues should be prioritized for debt reduction, particularly where public debt is high; saving funds for natural disasters, which should have strong institutional frameworks; and key infrastructure investment. 
37. More progress is needed in addressing financial sector fragilities, and strict enforcement of prudential requirements is critical. Updated asset quality reviews based on international best practices are necessary to provide effective guidance on provisioning and capital needs for indigenous banks. Strict enforcement of the 2015 Banking Act and of new regulation on asset classification would prompt the recognition of losses and the provision of capital to undercapitalized banks. Strong governance arrangements and risk-management frameworks should be put in place where needed to avoid further losses. Strict enforcement is also important to ensure a level playing field, promote healthy competition, and sector consolidation.

\section{New financial sector legislation should be finalized promptly. Activating the ECAMC} should not be further delayed with a clearly defined role, full independence of its operations, and adequately experienced staff. Harmonized legislation on asset quality should also be finalized rapidly. Foreclosure and insolvency legislation, a key obstacle in some countries to the reduction of NPLs and a more dynamic credit market, should be rebalanced to facilitate the recovery of impaired loans. Harmonized legislation on credit unions and insurance is also important to strengthen the non-bank financial sector. The draft law should be extended to building societies, articulate the need to improve the frequency of financial reporting, and specify sanctions for non-compliant entities. Moreover, it should clarify the definition of capital and the procedures to address NPLs.

\section{Steady progress towards stronger AML/CFT legislation and supervision is key to} securing CBRs. In this regard, the decision to transfer AML/CFT supervisory powers from national agencies to the ECCB is welcome and further steps are needed to harmonize AML/CFT legislation. Full compliance with the 2012 FATF standards and tax transparency standards should be prioritized. Bank consolidation and improved communications between respondent and correspondent banks would further reduce risks of losing CBRs.

40. Measures to remove financial market distortions would promote financial deepening. The MSR remains an obstacle to the efficient functioning of credit markets and it should be removed. This would facilitate the development of financial markets, providing alternative financial instruments for small savers. The functioning of the RGSM could also be improved, including by simplifying issuance procedures and reviewing brokers' fee structures. These measures could help reduce government borrowing costs.

\section{Structural reforms remain critical to address high unemployment, lack of} competitiveness, and low growth. The external position is weaker than implied by fundamentals and desirable policies, reflecting structural factors. Reducing costs of doing business remains a top priority. Additional efforts are needed to accelerate the implementation of renewable energy projects, which is lagging in some countries. Adequate preparedness would reduce the costs of natural disasters and their impact on growth. Furthering regional integration, particularly in goods and labor markets, connectivity, and financial regulation, is essential to boost competitiveness. Strengthening the link between wages and productivity, including through civil service reform, would support intersectoral labor mobility, helping to lower structural unemployment. 
42. Improving statistics is necessary to enhance the quality of surveillance and policy analysis. Data quality varies across ECCU countries, but capacity needs strengthening in several areas, including balance of payments, labor markets, and government finance. Removing legal impediments to the use of fiscal information would help supplement the external sector survey when the response rate is low.

43. The discussion with the ECCU authorities will be on the 12-month cycle in accordance with Decision No. 13655-(06/1), as amended. 
Figure 1. ECCU: Real Sector Developments
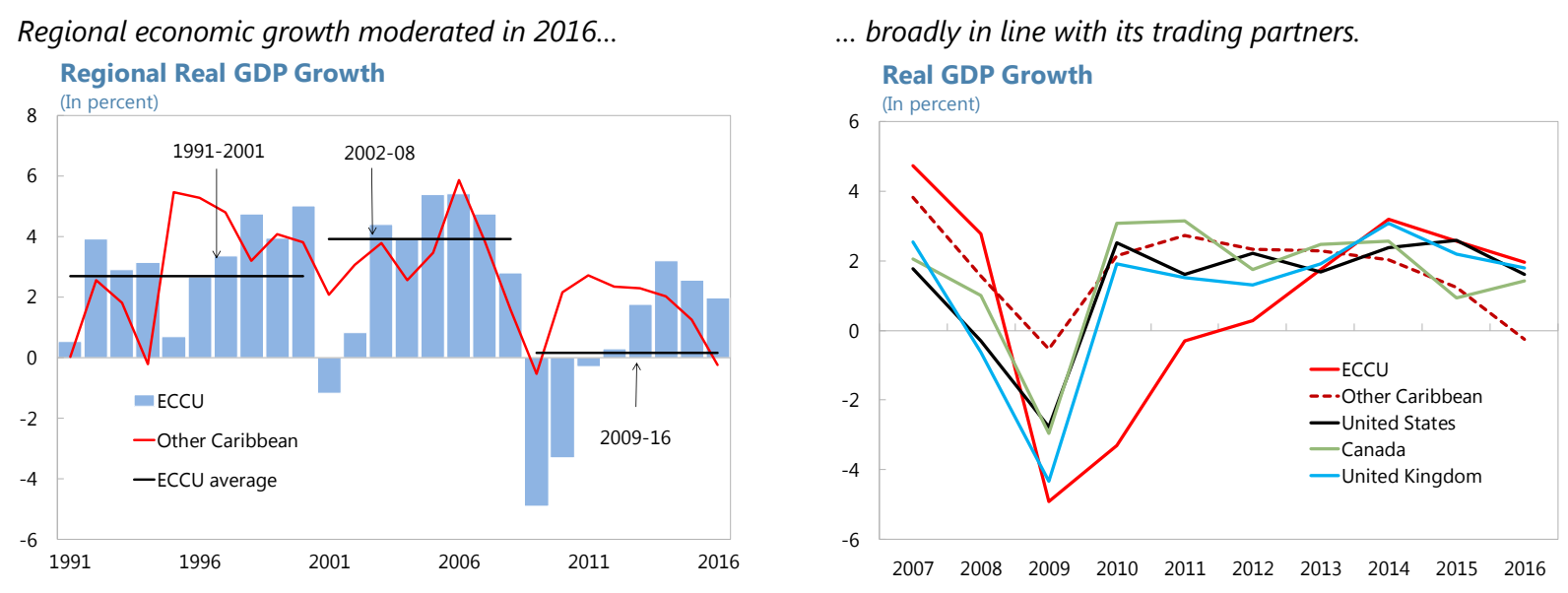

Economic activity, however, has gained momentum in many countries...

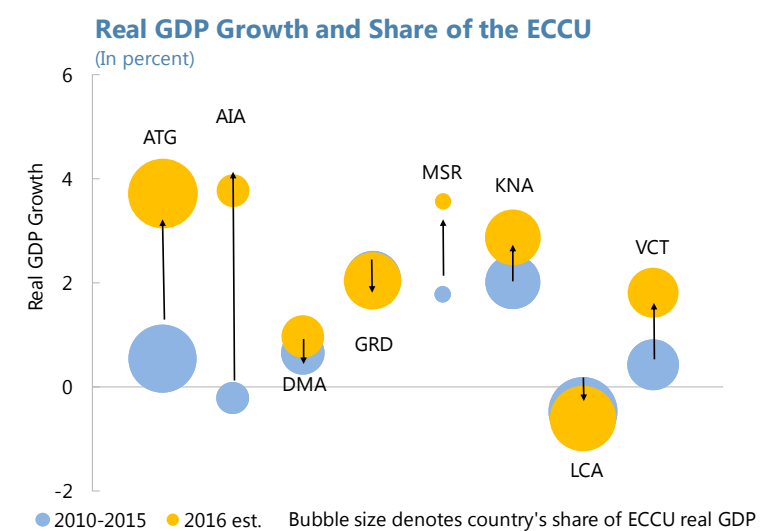

... largely because stronger construction.

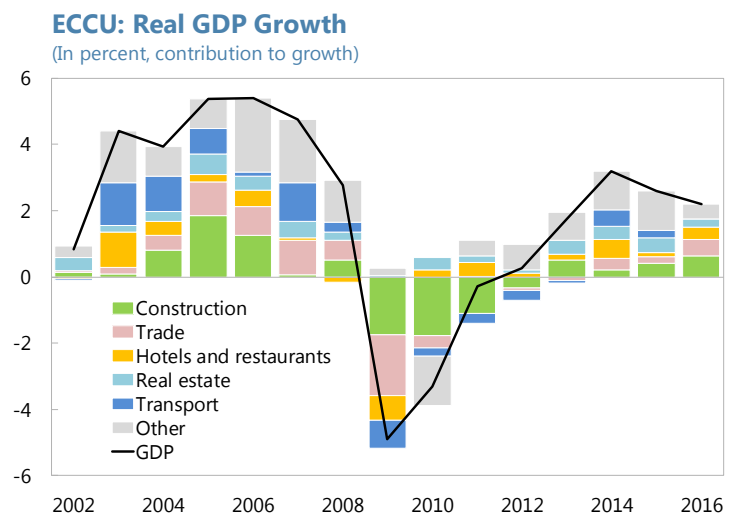

The output gap remains negative, which, along with declining global commodity and food prices, ...

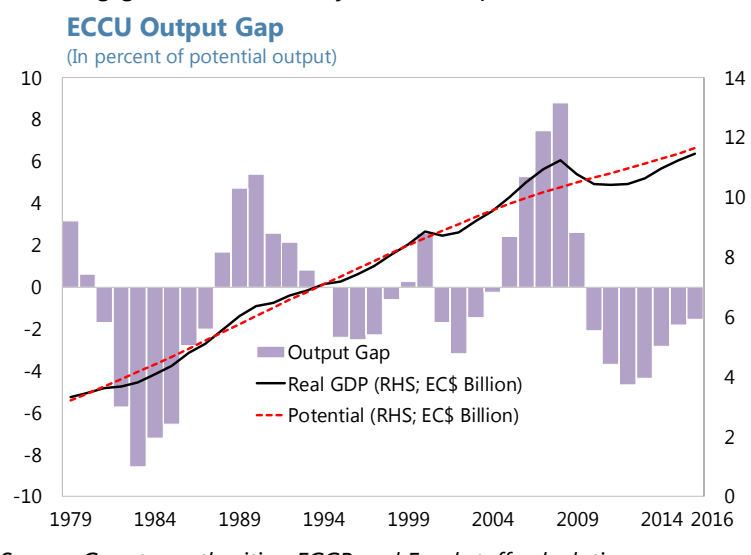

...has contributed to negative inflation in 2016.

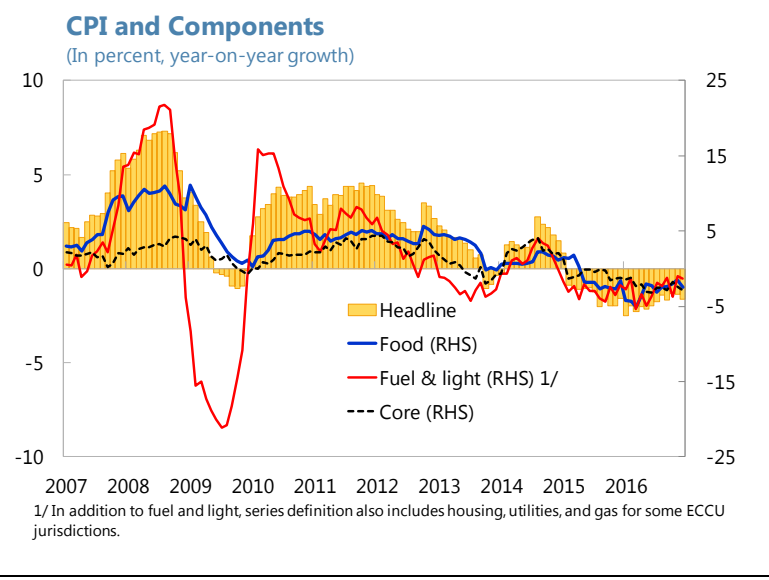


Figure 2. ECCU: Tourism Developments

Tourism is a key component of ECCU exports.

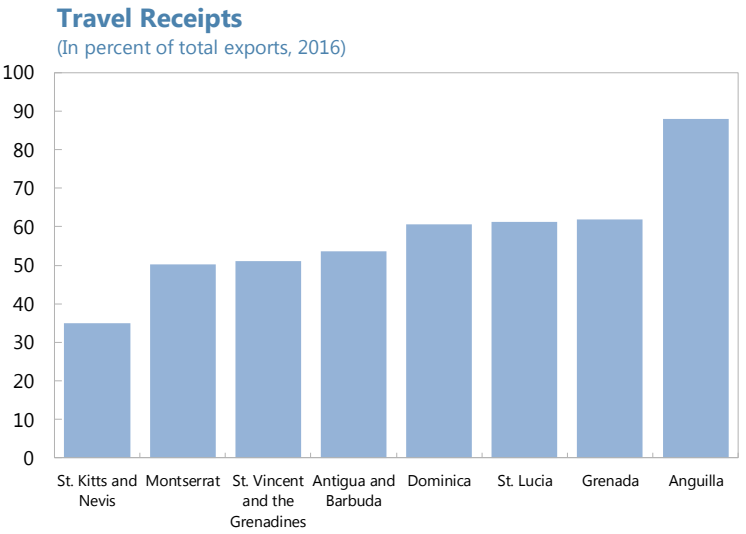

Tourism demand has increased in source markets...

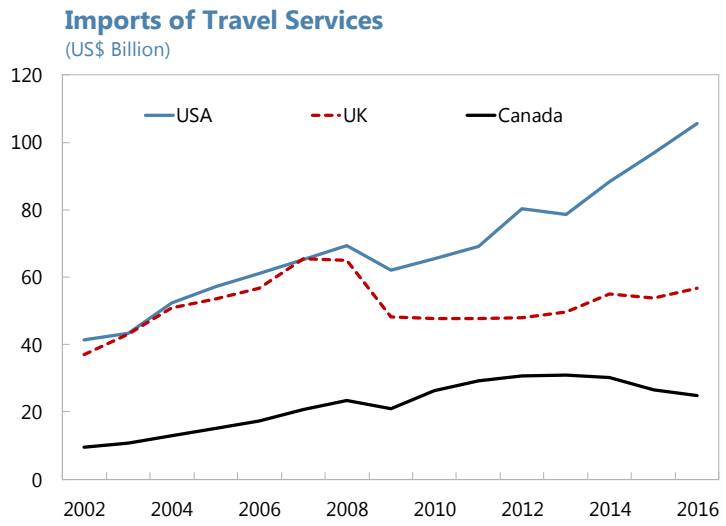

Tourist inflows picked up slightly in 2016, largely because U.S. travelers...

Stay-OverTourist Arrivals

(In percent, year-on-year contribution to growth, by country of origin)

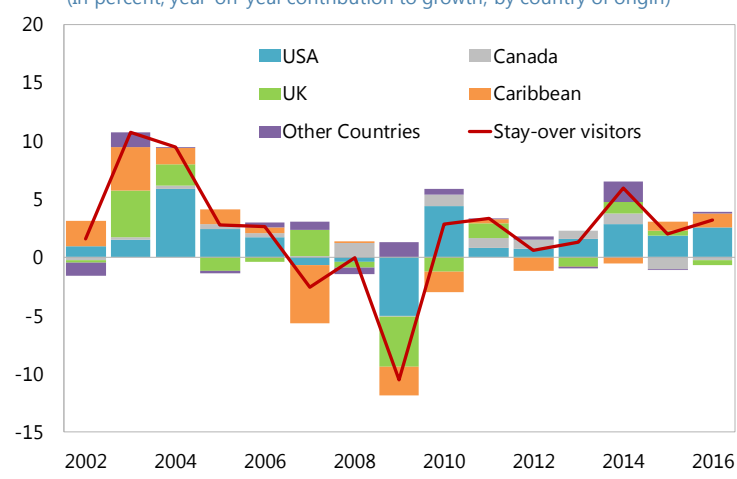

Source: ECCB, CTO and Fund staff calculations.
Almost $3 / 4$ of tourists come from North America and the U.K.

Inbound Tourism: by Source Market (In percent, 2015)

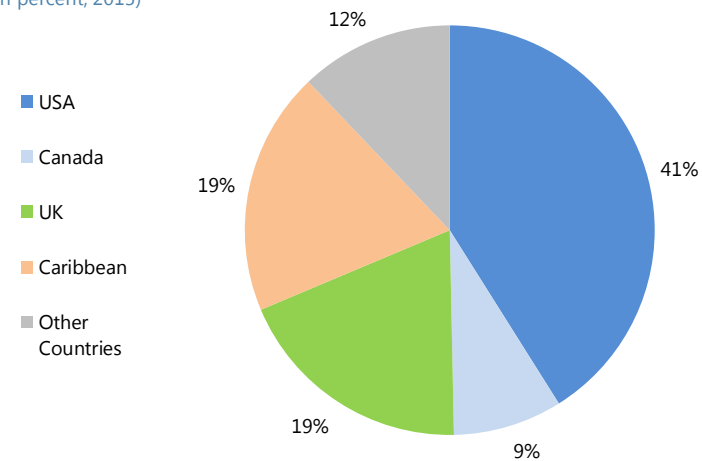

... but the ECCU's share has continued to fall.

ECCU Share of Travel Spending (US\$ billion)

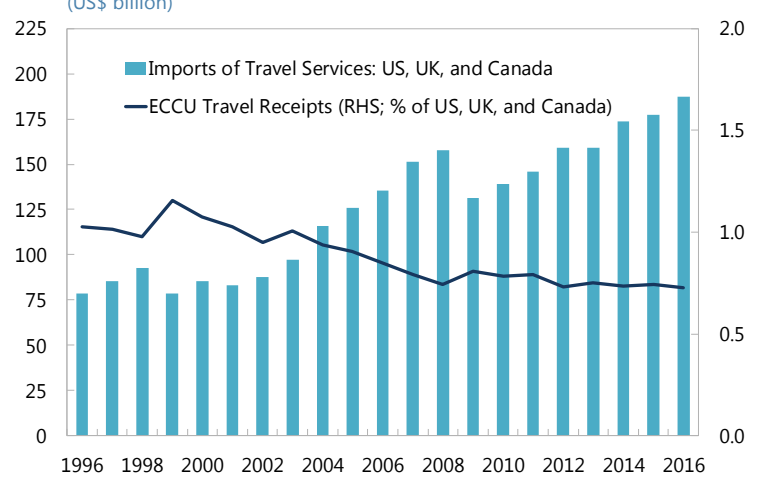

... and dependence on North American markets has increased in the last decade.

ECCU: Share of Stay-Over Tourist Arrivals (In percent of total, 2006 and 2016)

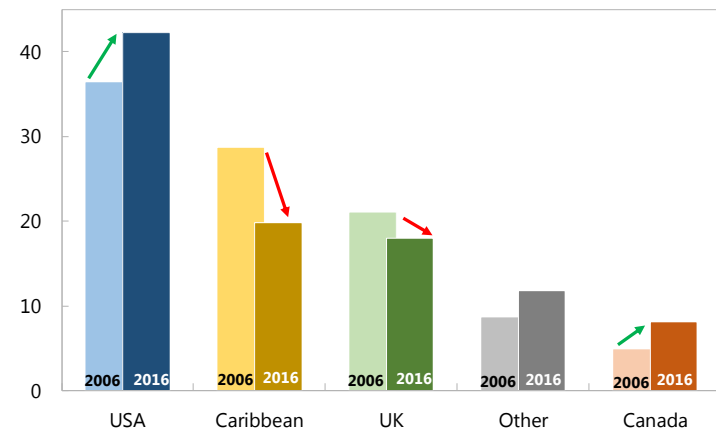

Sources: ECCB; and IMF staff estimates and calculations. 
Figure 3. ECCU: Monetary Developments

Excess reserves remain elevated in most jurisdictions ...

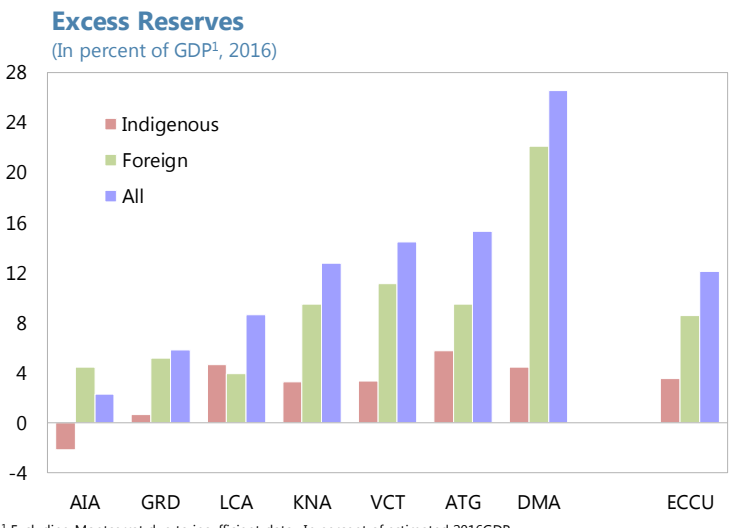

This reflected positive overall deposit growth...

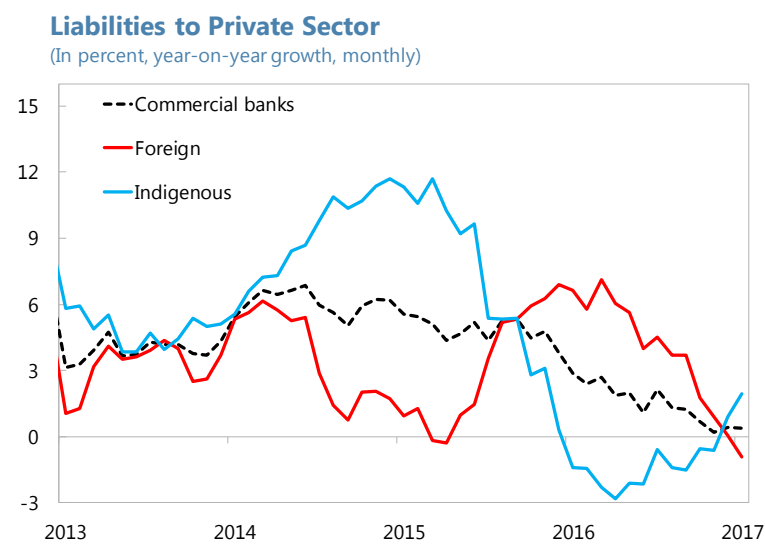

In conditions of excess liquidity and strong base money creation, the money multiplier continued to fall.

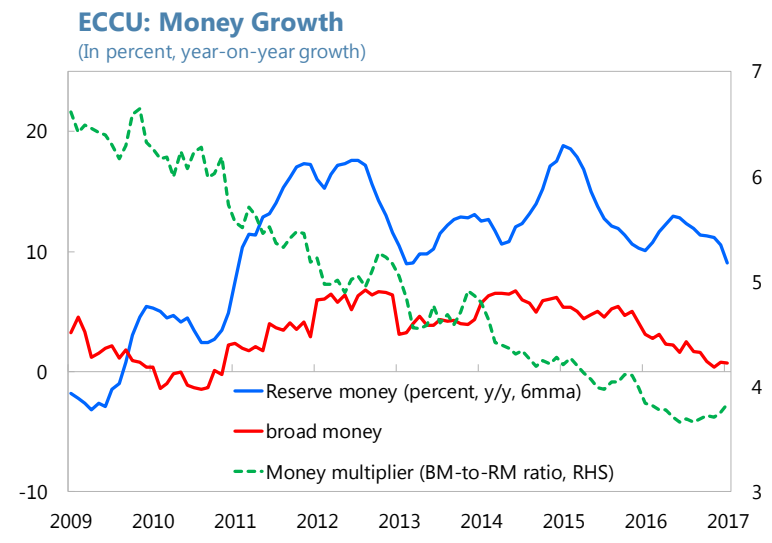

... and reached historically high levels in 2016.

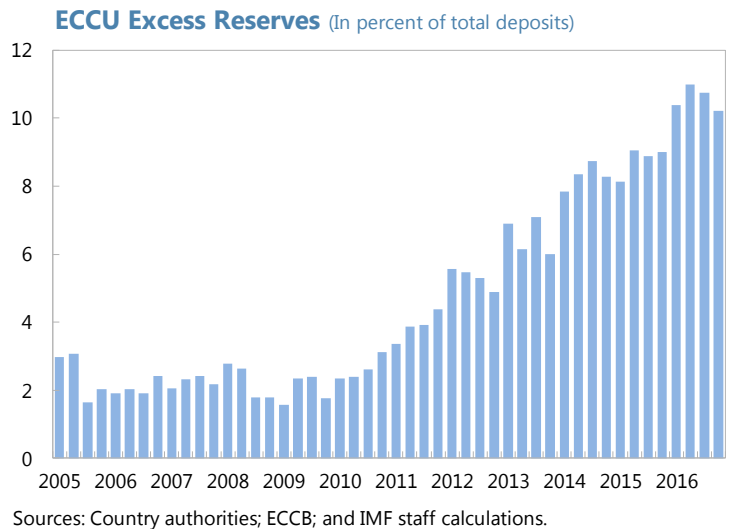

... and deeper credit contraction in 2016.

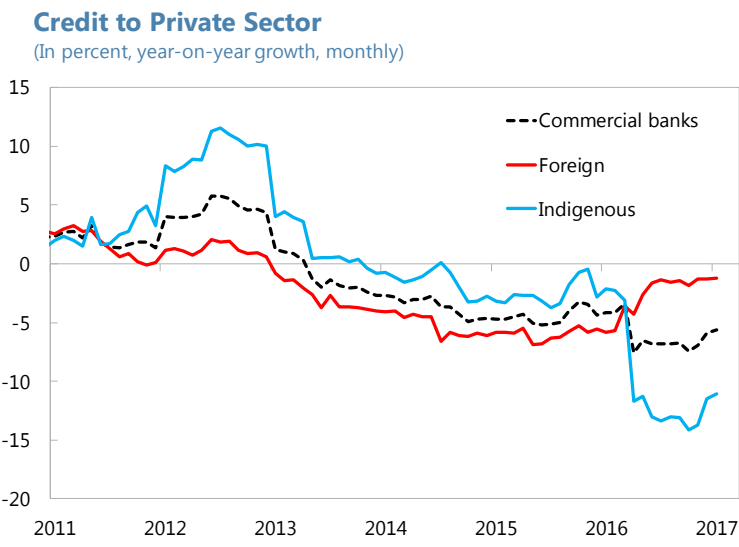

Monetary policy remained passive, and average deposit rates fell below the minimum saving deposit floor rate.

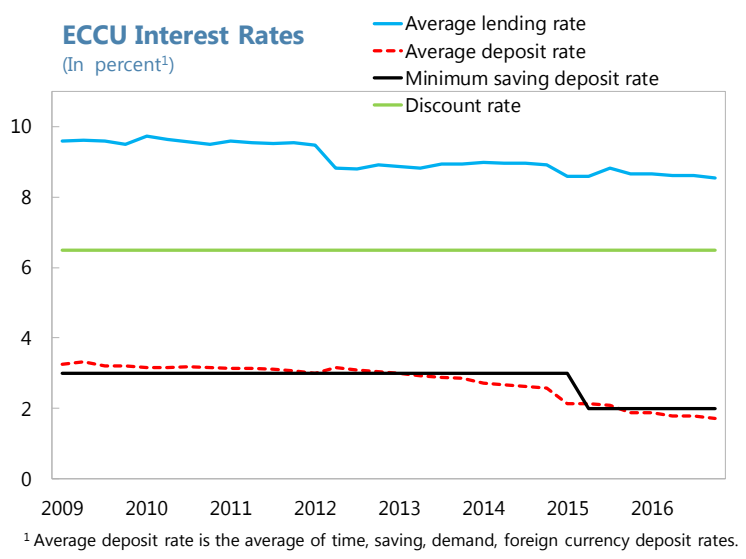


Figure 4. ECCU: Financial Soundness Indicators

NPL ratios declined to 12 percent at end-2016.

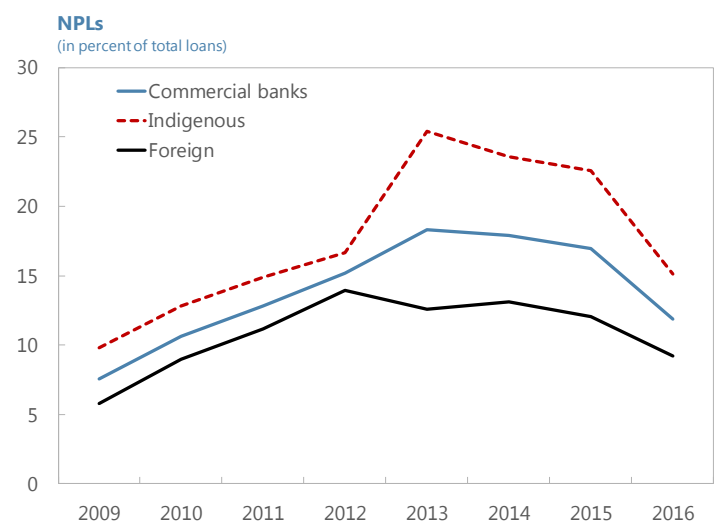

Profitability picked up in 2016, partly reflecting the lower minimum savings deposit rate....

Return on Average Assets

2.5 (In percent of total loans)

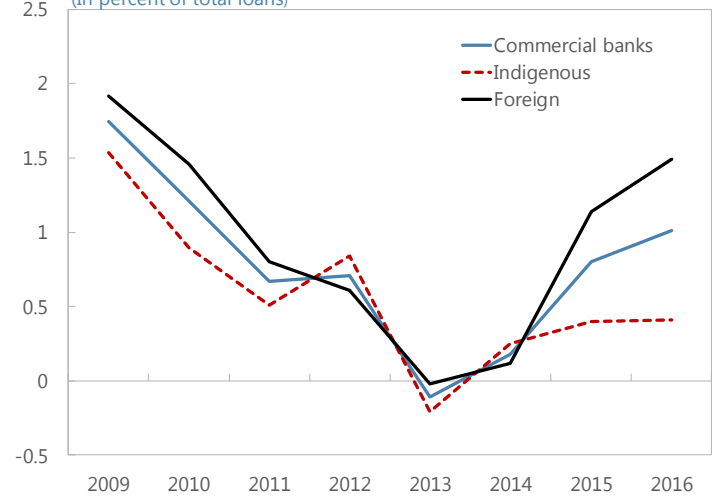

Excess liquidity has continued to boost banks' liquidity ratios....

Commercial Banks' Liquidity

(In percent)

—Liquid Assets/Total Assets (\%)

55

- Liquid Assets/Total Deposits (\%)

45

—Liquid Assets/(Total Deposits plus Liquid Liabilities) (\%) 100

---Loans and Advances/Total Deposits (\%, RHS)

35
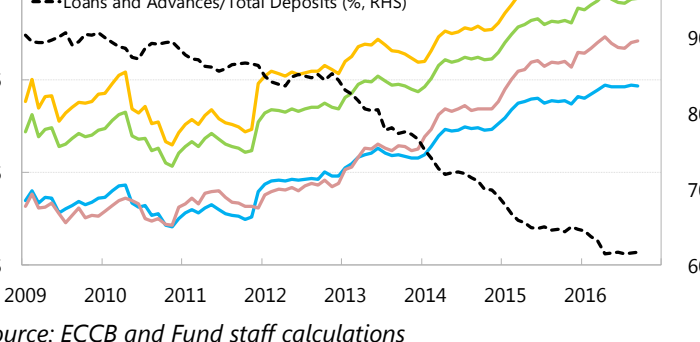

NPL provisioning continued to increase, but only among foreign banks.

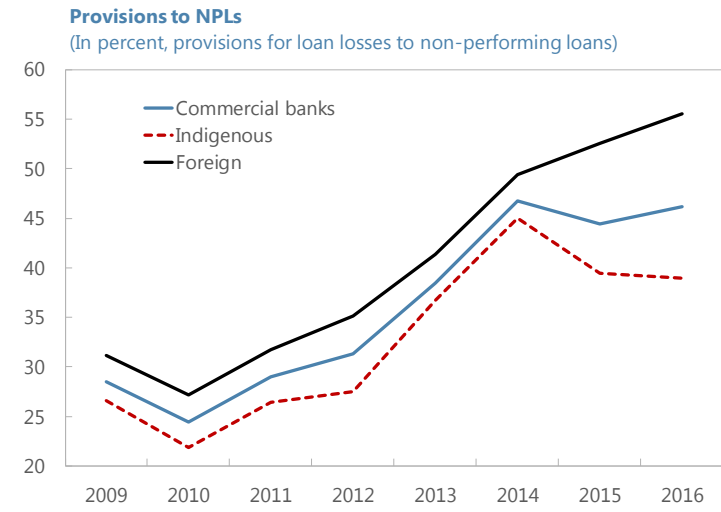

... and capital adequacy improved slightly.

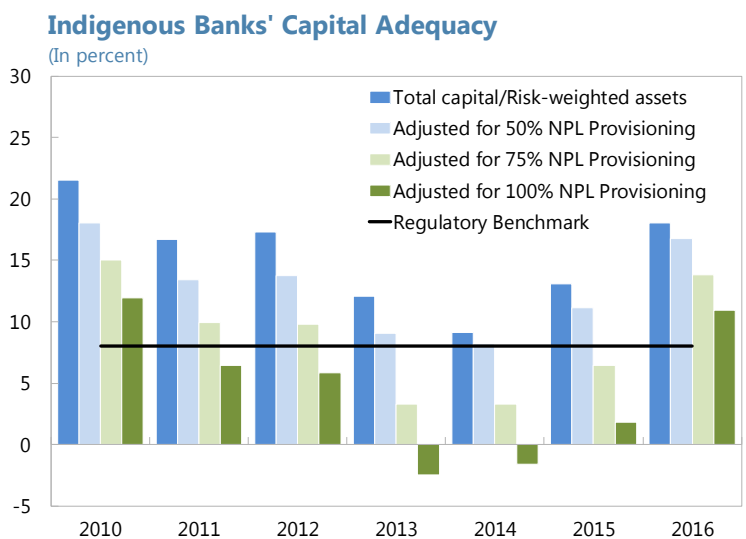

... particularly among foreign banks.

Cash Reserves / Total Deposits

(In percent)

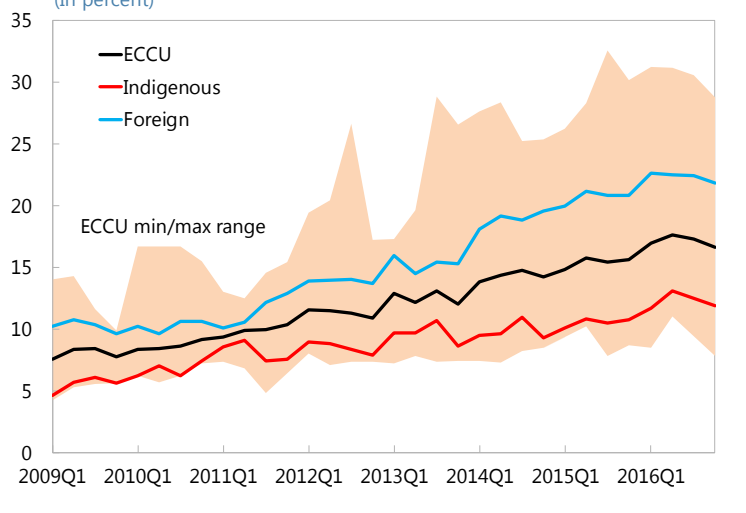




\section{Figure 5. ECCU: Doing Business Indicators ${ }^{1}$}

ECCU countries continue to exhibit large disparities in the ease of doing business, despite being relatively similar economies.

Doing Business (rank number)

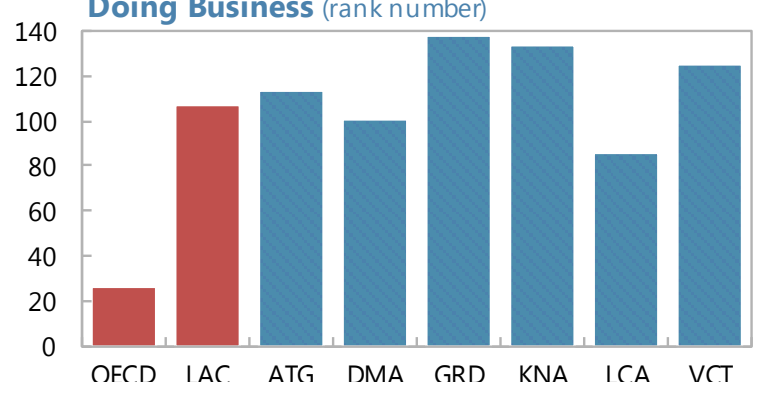

Registering Property (ranknumber)

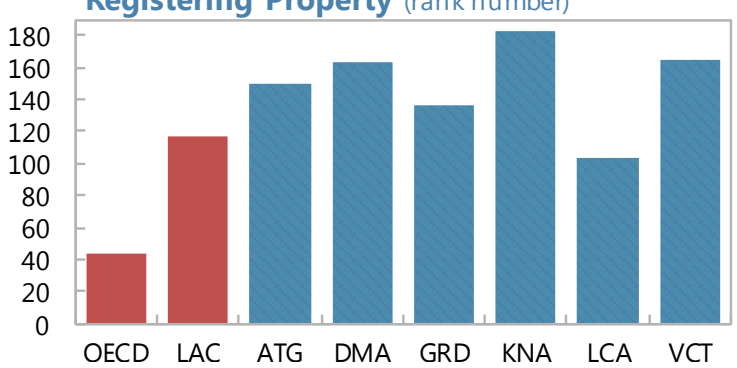

Closing a Business (rank number)

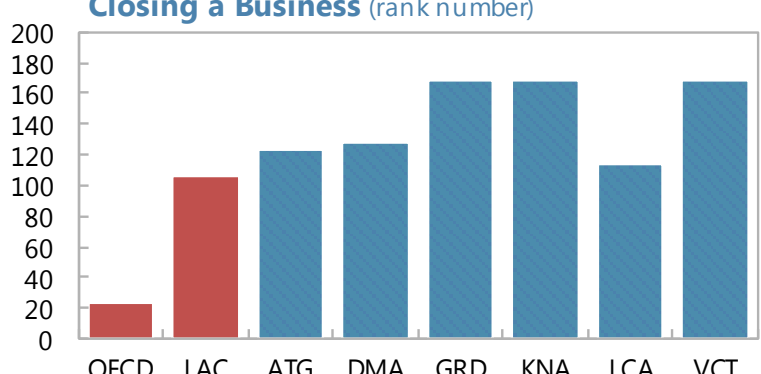
Doing Business (rank number)

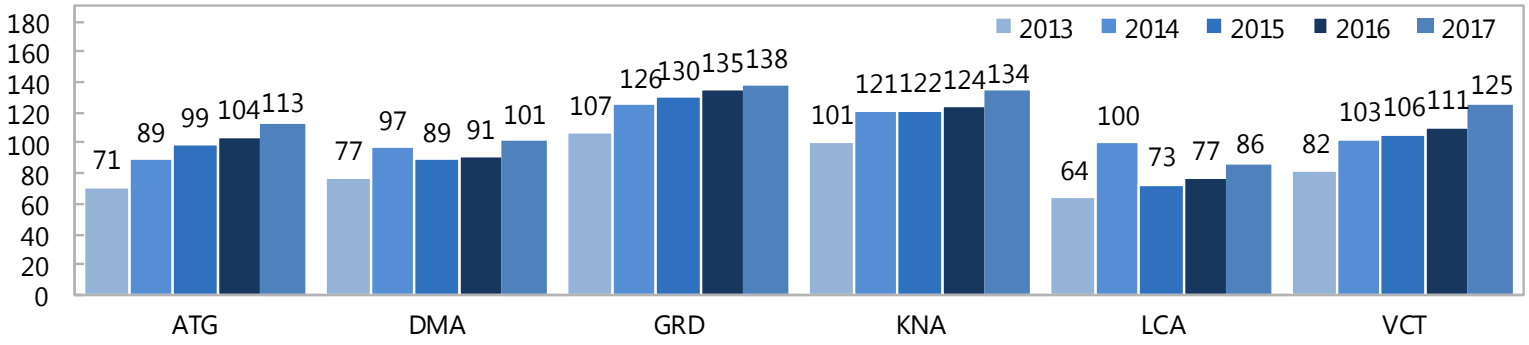

Sources: World Bank 2016Doing Business Indicators; and Fund staff calculations.

$1 /$ Smaller nu mbers represent greater ease in doing business. 2016 Doing Business rankings are across 189 cou ntries. These in dicators should be interpreted with caution due to a limited number of respondents, a limited geographical coverage, and standardized assumptions on business constraints and in formation availability.

2/ Annual rankings are rebased to adjust for different sample sizes.

Note: Antigua and Barbuda (ATG), Dominica (DMA), Grenada (GRD), St. Kitts and Nevis (KNA), St. Lucia (LCA), St. Vincent and the Grenadines (VCT), and Latin America and Caribbean (LAC). 


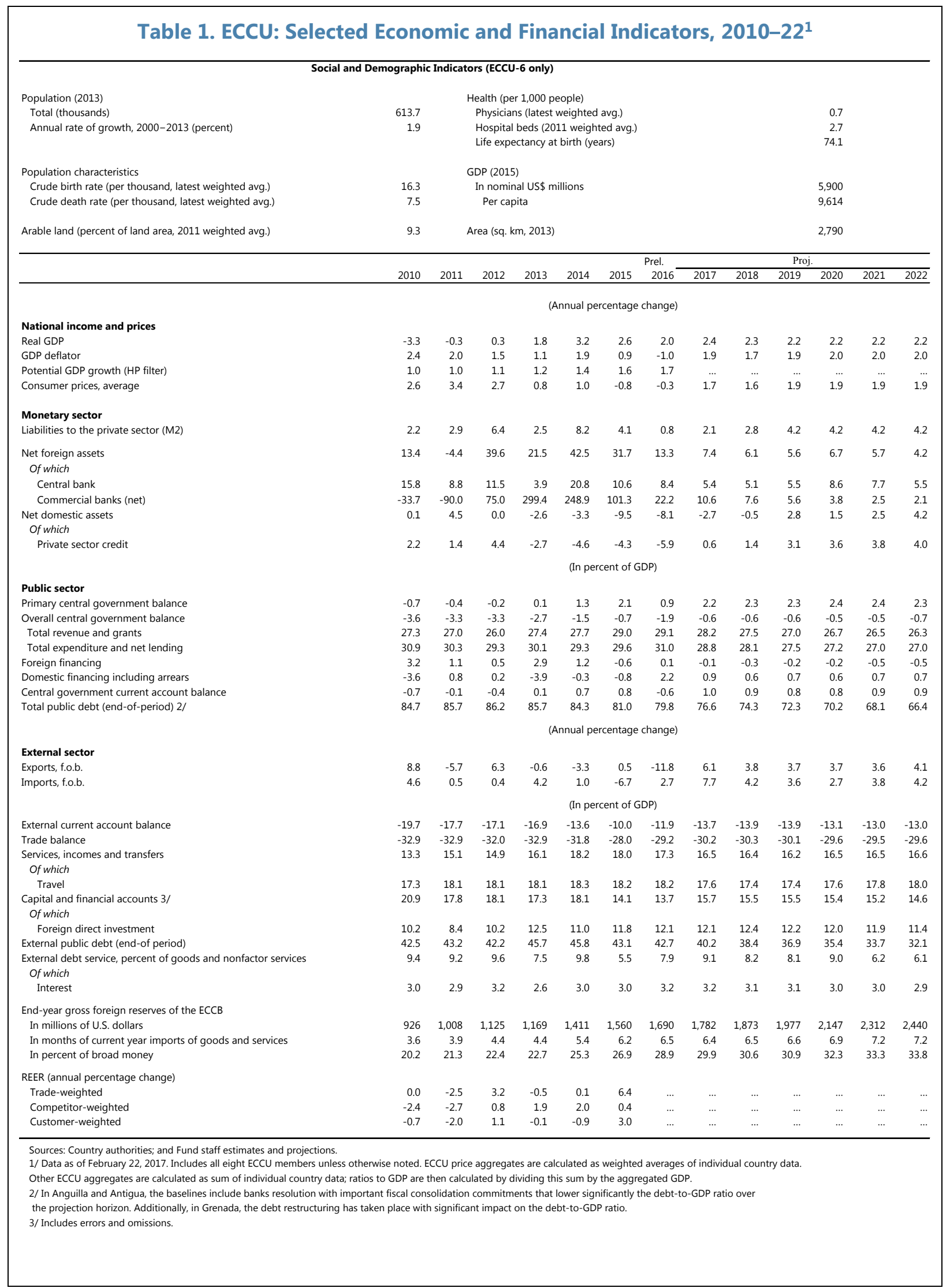


Table 2. ECCU: Selected Economic Indicators by Country, 2010-22

\begin{tabular}{|c|c|c|c|c|c|c|c|c|c|c|c|c|c|}
\hline & & & & & & & $\begin{array}{l}\text { Prel. } \\
\end{array}$ & & & Proj & & & \\
\hline & 2010 & 2011 & 2012 & 2013 & 2014 & $2015^{-}$ & 2016 & 2017 & 2018 & 2019 & 2020 & 2021 & 2022 \\
\hline \multicolumn{14}{|c|}{ (Annual percentage change) } \\
\hline Real GDP (ECCU-8) & -3.3 & -0.3 & 0.3 & 1.8 & 3.2 & 2.6 & 2.0 & 2.4 & 2.3 & 2.2 & 2.2 & 2.2 & 2.2 \\
\hline Anguilla & -5.8 & -2.6 & -1.9 & 0.5 & 5.6 & 2.8 & 3.8 & 3.1 & 3.2 & 3.3 & 2.8 & 2.8 & 2.8 \\
\hline Antigua and Barbuda & -8.4 & -1.8 & 3.5 & 1.4 & 4.8 & 3.8 & 3.7 & 2.2 & 1.7 & 1.7 & 1.7 & 1.7 & 1.7 \\
\hline Dominica & 0.7 & 0.8 & -0.8 & 1.9 & 3.7 & -2.5 & 1.0 & 3.6 & 3.3 & 2.2 & 2.1 & 1.8 & 1.5 \\
\hline Grenada & -2.0 & 0.1 & -0.6 & 3.2 & 6.5 & 5.2 & 2.0 & 2.4 & 2.2 & 2.2 & 2.5 & 2.7 & 2.7 \\
\hline Montserrat & -3.0 & 6.2 & 1.6 & 5.3 & 0.3 & 0.3 & 3.6 & 1.7 & 2.0 & 2.2 & 2.2 & 2.2 & 2.2 \\
\hline St. Kitts and Nevis & -2.9 & -0.8 & -0.8 & 6.6 & 5.1 & 4.9 & 2.9 & 3.2 & 3.2 & 2.9 & 2.8 & 2.8 & 2.7 \\
\hline St. Lucia & -0.8 & 0.7 & -1.2 & -2.1 & -0.7 & 1.2 & -0.6 & 1.2 & 1.5 & 1.5 & 1.5 & 1.5 & 1.5 \\
\hline St. Vincent and the Grenadines & -2.3 & 0.2 & 1.3 & 2.5 & 0.2 & 0.6 & 1.8 & 2.5 & 2.8 & 2.9 & 3.0 & 3.0 & 2.8 \\
\hline CPI (end of period) & 3.1 & 3.8 & 2.2 & -0.1 & 0.9 & -0.9 & 0.3 & 1.8 & 1.7 & 1.9 & 1.9 & 1.9 & 1.9 \\
\hline Anguilla & 3.8 & 4.4 & -0.3 & 0.8 & -0.9 & -1.7 & -0.4 & 1.6 & 1.9 & 2.3 & 2.3 & 2.3 & 2.3 \\
\hline Antigua and Barbuda & 2.9 & 4.0 & 1.8 & 1.1 & 1.3 & 0.9 & -0.6 & 2.3 & 2.4 & 2.5 & 2.5 & 2.5 & 2.5 \\
\hline Dominica & 0.0 & 1.9 & 1.3 & -0.4 & 0.5 & -0.5 & -0.2 & 1.4 & 1.4 & 1.8 & 1.8 & 2.0 & 2.0 \\
\hline Grenada & 4.2 & 3.5 & 1.8 & -1.2 & -0.6 & 1.1 & 0.9 & 3.0 & 1.8 & 1.9 & 1.9 & 1.9 & 1.9 \\
\hline Montserrat & 2.5 & 4.4 & 3.6 & -0.5 & -0.9 & -0.1 & -1.3 & 1.0 & 1.5 & 2.0 & 2.0 & 2.0 & 2.0 \\
\hline St. Kitts and Nevis & 4.3 & 2.0 & 0.5 & 0.6 & -0.5 & -2.4 & 0.9 & 1.5 & 2.0 & 2.0 & 2.0 & 2.0 & 2.0 \\
\hline St. Lucia & 4.2 & 4.8 & 5.0 & -0.7 & 3.7 & -2.6 & 0.6 & 0.7 & 1.1 & 1.5 & 1.5 & 1.5 & 1.5 \\
\hline St. Vincent and the Grenadines & 0.9 & 4.7 & 1.0 & 0.0 & 0.1 & -2.1 & 1.0 & 1.7 & 1.3 & 1.4 & 1.4 & 1.4 & 1.4 \\
\hline CPI (period average) & 2.6 & 3.4 & 2.7 & 0.8 & 1.0 & -0.8 & -0.3 & 1.7 & 1.6 & 1.9 & 1.9 & 1.9 & 1.9 \\
\hline Anguilla & 2.1 & 4.7 & 1.4 & 0.1 & -0.3 & -1.0 & -0.5 & 2.0 & 2.3 & 2.3 & 2.3 & 2.3 & 2.3 \\
\hline Antigua and Barbuda & 3.4 & 3.5 & 3.4 & 1.1 & 1.1 & 1.0 & -0.4 & 1.7 & 2.4 & 2.5 & 2.5 & 2.5 & 2.5 \\
\hline Dominica & 2.8 & 1.1 & 1.4 & 0.0 & 0.8 & -0.8 & 0.0 & 0.6 & 1.4 & 1.6 & 1.8 & 1.9 & 2.0 \\
\hline Grenada & 3.4 & 3.0 & 2.4 & 0.0 & -1.0 & -0.6 & 1.7 & 2.6 & 2.0 & 1.8 & 1.9 & 1.9 & 1.9 \\
\hline Montserrat & 2.1 & 3.7 & 4.8 & 0.9 & -0.4 & -1.1 & -0.2 & 1.0 & 1.5 & 2.0 & 2.0 & 2.0 & 2.0 \\
\hline St. Kitts and Nevis & 0.9 & 5.8 & 0.8 & 1.1 & 0.2 & -2.3 & -0.7 & 1.2 & 1.8 & 2.0 & 2.0 & 2.0 & 2.0 \\
\hline St. Lucia & 3.3 & 2.8 & 4.2 & 1.5 & 3.5 & -1.0 & -1.7 & 1.9 & 0.7 & 1.5 & 1.5 & 1.4 & 1.5 \\
\hline St. Vincent and the Grenadines & 0.8 & 3.2 & 2.6 & 0.8 & 0.2 & -1.7 & -0.2 & 1.3 & 1.3 & 1.4 & 1.4 & 1.4 & 1.4 \\
\hline Private sector credit & 2.2 & 1.4 & 4.4 & -2.7 & -4.6 & -4.3 & -5.9 & 0.6 & 1.4 & 3.1 & 3.6 & 3.8 & 4.0 \\
\hline Anguilla & 0.2 & 0.1 & -3.4 & -3.5 & -3.8 & -3.5 & -47.0 & 1.2 & 3.0 & 3.8 & 4.0 & 4.0 & 4.0 \\
\hline Antigua and Barbuda & 0.2 & -4.4 & -2.8 & -4.0 & -5.2 & -11.3 & 5.8 & 2.5 & 4.8 & 4.7 & 6.2 & 6.5 & 6.7 \\
\hline Dominica & 9.5 & 6.6 & 4.3 & -0.7 & -2.2 & 0.3 & 2.9 & 4.0 & 3.7 & 4.0 & 3.9 & 3.8 & 4.0 \\
\hline Grenada & 5.6 & 2.2 & 0.2 & -5.7 & -5.1 & -3.8 & 4.1 & 2.7 & 4.5 & 4.4 & 4.6 & 4.9 & 4.9 \\
\hline Montserrat & 16.1 & 10.7 & 9.9 & -11.0 & 0.4 & 5.4 & 13.5 & 5.7 & 5.4 & 5.5 & 5.2 & 5.4 & 5.3 \\
\hline St. Kitts and Nevis & 3.5 & 3.7 & 0.2 & -0.9 & 0.6 & 3.2 & -0.4 & 3.5 & 3.8 & 3.8 & 4.5 & 5.0 & 5.0 \\
\hline St. Lucia & 1.1 & 2.6 & 5.1 & -0.8 & -6.7 & -6.8 & -4.8 & 0.0 & 0.0 & 0.0 & 3.0 & 3.0 & 3.1 \\
\hline St. Vincent and the Grenadines & 1.8 & 4.1 & 3.5 & 1.3 & -0.2 & 2.4 & 1.3 & 0.0 & 1.0 & 1.0 & 1.0 & 2.0 & 2.0 \\
\hline Net credit to public sector & -123.8 & 47.6 & -146.8 & -1721.4 & -71.9 & 164.5 & 30.5 & -0.3 & 2.7 & -0.1 & 2.1 & 2.7 & 1.8 \\
\hline Anguilla & 443.4 & 19.1 & 12.6 & 9.3 & 7.6 & 1.5 & -60.0 & 1.5 & 1.7 & 1.8 & 1.9 & 1.9 & 2.0 \\
\hline Antigua and Barbuda & -16.1 & -7.4 & -26.7 & 42.8 & 13.5 & -8.0 & -25.7 & -6.7 & -15.3 & -16.7 & -19.1 & -23.4 & -41.0 \\
\hline Dominica & -1.1 & -30.6 & 37.9 & -103.5 & 490.0 & -334.0 & 384.3 & 0.9 & 1.1 & 0.8 & 0.9 & 0.8 & -67.2 \\
\hline Grenada & -1661.2 & -17.1 & -152.9 & -194.3 & 239.7 & 128.7 & 24.1 & 5.7 & 5.2 & 5.0 & 2.0 & 2.2 & 2.2 \\
\hline Montserrat & 7.9 & 57.3 & 25.5 & -16.9 & -3.5 & 37.5 & -6.6 & 13.5 & 7.4 & 9.7 & 7.9 & 7.4 & 6.9 \\
\hline St. Kitts and Nevis $1 /$ & 21.9 & -35.8 & -73.4 & -1117.6 & 43.4 & 2.1 & 5.5 & -4.4 & -3.6 & -7.3 & -6.6 & -6.3 & -7.2 \\
\hline St. Lucia & 35.6 & -26.1 & -37.5 & -59.1 & 168.7 & 27.4 & -36.7 & -47.7 & -63.1 & -163.3 & 270.9 & 51.2 & 34.7 \\
\hline St. Vincent and the Grenadines & -82.5 & 99.2 & 11.3 & 23.5 & 44.9 & 25.4 & -45.6 & 48.9 & 27.7 & 13.2 & 5.5 & 3.5 & 0.0 \\
\hline Current account balances (percent GDP) & -19.7 & -17.7 & -17.1 & -16.9 & -13.6 & -10.0 & -11.9 & -13.7 & -13.9 & -13.9 & -13.1 & -13.0 & -13.0 \\
\hline Anguilla & -18.9 & -12.7 & -19.4 & -17.7 & -20.9 & -21.3 & -24.6 & -24.6 & -24.7 & -24.9 & -25.2 & -25.6 & -25.6 \\
\hline Antigua and Barbuda & -14.6 & -10.3 & -14.8 & -15.1 & -12.5 & -5.2 & -5.9 & -9.8 & -9.6 & -9.6 & -9.7 & -9.7 & -9.7 \\
\hline Dominica & -15.9 & -14.1 & -17.3 & -9.7 & -9.5 & -8.0 & -11.8 & -12.1 & -16.6 & -16.0 & -13.2 & -10.3 & -10.3 \\
\hline Grenada & -23.7 & -23.6 & -21.1 & -23.2 & -17.5 & -17.5 & -14.6 & -15.4 & -15.0 & -15.0 & -14.4 & -14.4 & -14.4 \\
\hline Montserrat & -35.1 & -15.8 & -21.7 & -48.8 & -20.3 & -2.8 & -9.8 & -10.7 & -10.2 & -11.9 & -3.4 & -6.9 & -6.9 \\
\hline St. Kitts and Nevis & -20.3 & -13.0 & -8.3 & -11.3 & -8.1 & -9.2 & -16.0 & -18.5 & -17.7 & -18.2 & -17.6 & -16.9 & -16.9 \\
\hline St. Lucia & -16.3 & -19.0 & -13.5 & -11.1 & -8.9 & -2.6 & -6.7 & -8.8 & -9.3 & -8.9 & -8.9 & -8.9 & -8.9 \\
\hline St. Vincent and the Grenadines & -30.6 & -29.4 & -27.6 & -30.9 & -25.1 & -21.2 & -18.9 & -18.2 & -17.4 & -16.8 & -16.2 & -15.5 & -15.5 \\
\hline Trade balances (percent GDP) & -32.9 & -32.9 & -32.0 & -32.9 & -31.8 & -28.0 & -29.2 & -30.2 & -30.3 & -30.1 & -29.6 & -29.5 & -29.5 \\
\hline Anguilla & -44.6 & -41.6 & -43.5 & -44.4 & -42.2 & -43.8 & -45.8 & -45.8 & -46.0 & -46.1 & -46.4 & -46.8 & -46.8 \\
\hline Antigua and Barbuda & -35.6 & -32.8 & -35.7 & -36.8 & -35.2 & -28.4 & -28.1 & -31.1 & -31.4 & -31.5 & -31.6 & -31.8 & -31.8 \\
\hline Dominica & -32.0 & -33.0 & -30.2 & -27.6 & -31.1 & -30.1 & -36.6 & -39.9 & -42.1 & -39.9 & -36.9 & -33.8 & -33.8 \\
\hline Grenada & -33.0 & -33.2 & -32.2 & -33.1 & -28.0 & -27.2 & -27.4 & -27.7 & -27.7 & -27.9 & -27.7 & -27.8 & -27.8 \\
\hline Montserrat & -44.8 & -42.8 & -49.5 & -52.6 & -56.2 & -52.8 & -44.7 & -55.2 & -49.3 & -48.7 & -36.4 & -37.4 & -37.4 \\
\hline St. Kitts and Nevis & -28.6 & -25.1 & -23.5 & -31.2 & -30.0 & -27.4 & -28.4 & -27.8 & -27.1 & -26.5 & -26.5 & -26.6 & -26.6 \\
\hline St. Lucia & -27.7 & -32.9 & -27.3 & -26.2 & -26.5 & -20.6 & -23.3 & -23.7 & -23.5 & -23.3 & -23.3 & -23.3 & -23.3 \\
\hline St. Vincent and the Grenadines & -37.1 & -36.8 & -38.4 & -37.7 & -36.5 & -33.0 & -32.1 & -31.6 & -31.2 & -30.9 & -30.5 & -30.2 & -30.2 \\
\hline Foreign direct investment (percent GDP) & 10.2 & 8.4 & 10.2 & 12.5 & 11.0 & 11.8 & 12.1 & 12.1 & 12.4 & 12.2 & 12.0 & 11.9 & 11.9 \\
\hline Anguilla & 4.3 & 13.3 & 15.5 & 14.9 & 25.5 & 26.7 & 26.3 & 25.5 & 24.7 & 23.9 & 23.1 & 22.4 & 22.4 \\
\hline Antigua and Barbuda & 8.4 & 5.7 & 11.0 & 7.9 & 9.3 & 9.1 & 9.1 & 9.6 & 9.9 & 10.2 & 10.6 & 11.0 & 11.0 \\
\hline Dominica & 8.7 & 6.9 & 12.0 & 4.6 & 6.3 & 6.6 & 9.0 & 10.3 & 12.7 & 12.6 & 10.5 & 8.3 & 8.3 \\
\hline Grenada & 7.8 & 5.5 & 3.9 & 13.4 & 4.1 & 9.9 & 8.3 & 8.6 & 8.7 & 9.2 & 9.2 & 9.2 & 9.2 \\
\hline Montserrat & 6.4 & 3.9 & 4.2 & 6.3 & 10.5 & 7.0 & 6.7 & 7.0 & 6.9 & 6.9 & 6.9 & 6.9 & 6.9 \\
\hline St. Kitts and Nevis & 16.5 & 14.6 & 14.8 & 23.6 & 22.5 & 20.7 & 20.5 & 19.9 & 19.1 & 18.2 & 17.6 & 16.9 & 16.9 \\
\hline St. Lucia & 9.8 & 6.3 & 5.7 & 7.0 & 6.5 & 6.5 & 6.8 & 6.8 & 7.0 & 7.1 & 7.1 & 7.2 & 7.2 \\
\hline St. Vincent and the Grenadines & 14.3 & 12.7 & 16.6 & 22.1 & 15.0 & 16.3 & 18.1 & 17.6 & 17.2 & 16.8 & 16.6 & 16.1 & 16.1 \\
\hline
\end{tabular}


Table 3. ECCU: Selected Central Government Fiscal Indicators by Country, 2010-221

\begin{tabular}{|c|c|c|c|c|c|c|c|c|c|c|c|c|c|}
\hline & & & & & & & Prel. & & & Pro & & & \\
\hline & 2010 & 2011 & 2012 & 2013 & 2014 & 2015 & 2016 & 2017 & 2018 & 2019 & 2020 & 2021 & 2022 \\
\hline Total revenues and grants & 27.3 & 27.0 & 26.0 & 27.4 & 27.7 & 29.0 & 29.1 & 28.2 & 27.5 & 27.0 & 26.7 & 26.5 & 26.3 \\
\hline Anguilla 2/ & 24.6 & 25.4 & 25.2 & 24.8 & 23.9 & 22.6 & 22.3 & 27.9 & 25.0 & 25.0 & 22.8 & 22.8 & 22.7 \\
\hline Antigua and Barbuda 3 / & 22.3 & 20.3 & 19.7 & 18.7 & 19.8 & 23.8 & 25.6 & 22.8 & 21.9 & 21.6 & 21.5 & 21.4 & 21.2 \\
\hline Dominica & 36.0 & 30.8 & 30.4 & 30.0 & 27.6 & 33.9 & 37.5 & 36.9 & 34.0 & 33.0 & 32.6 & 32.1 & 32.0 \\
\hline Grenada & 24.6 & 23.6 & 20.8 & 20.9 & 24.5 & 24.8 & 26.8 & 26.5 & 26.1 & 25.9 & 25.7 & 25.3 & 25.0 \\
\hline Montserrat & 80.9 & 78.0 & 82.6 & 95.8 & 94.3 & 113.5 & 78.9 & 92.9 & 85.9 & 81.2 & 79.2 & 76.7 & 74.1 \\
\hline St. Kitts and Nevis & 29.9 & 35.4 & 36.1 & 45.1 & 42.2 & 38.8 & 32.7 & 30.3 & 30.1 & 27.6 & 27.3 & 27.1 & 26.9 \\
\hline St. Lucia & 25.9 & 26.4 & 25.0 & 25.6 & 25.7 & 27.0 & 28.0 & 27.2 & 27.2 & 27.2 & 27.3 & 27.3 & 27.3 \\
\hline St. Vincent and the Grenadines & 29.0 & 27.4 & 26.1 & 26.9 & 29.3 & 28.6 & 29.2 & 28.6 & 28.9 & 29.1 & 29.1 & 29.1 & 29.1 \\
\hline Current expenditure & 24.2 & 24.1 & 24.2 & 24.3 & 24.0 & 24.6 & 26.1 & 24.0 & 23.8 & 23.6 & 23.5 & 23.4 & 23.3 \\
\hline Anguilla 2/ & 26.9 & 22.1 & 22.8 & 23.3 & 21.6 & 21.7 & 57.4 & 21.8 & 21.2 & 20.4 & 19.7 & 19.1 & 18.5 \\
\hline Antigua and Barbuda 3/ & 20.5 & 22.0 & 20.1 & 20.9 & 21.0 & 25.0 & 21.6 & 19.8 & 19.9 & 20.0 & 20.2 & 20.3 & 20.4 \\
\hline Dominica & 23.2 & 23.5 & 25.3 & 23.9 & 25.3 & 26.8 & 26.2 & 25.8 & 24.8 & 24.2 & 24.0 & 23.5 & 23.1 \\
\hline Grenada & 21.0 & 21.0 & 21.7 & 21.1 & 19.9 & 17.6 & 20.2 & 19.9 & 19.6 & 19.3 & 18.9 & 18.7 & 18.6 \\
\hline Montserrat & 58.8 & 54.2 & 66.2 & 67.1 & 74.0 & 75.5 & 67.0 & 70.7 & 68.8 & 65.6 & 63.8 & 62.8 & 60.9 \\
\hline St. Kitts and Nevis & 30.4 & 29.5 & 27.6 & 26.4 & 26.6 & 26.1 & 25.7 & 25.3 & 24.8 & 23.9 & 23.7 & 23.7 & 23.5 \\
\hline St. Lucia & 22.0 & 22.4 & 24.5 & 26.0 & 25.0 & 25.4 & 26.8 & 27.1 & 27.4 & 27.8 & 28.2 & 28.5 & 28.8 \\
\hline St. Vincent and the Grenadines & 28.3 & 27.1 & 26.2 & 25.2 & 25.9 & 25.7 & 24.9 & 25.9 & 25.3 & 25.2 & 25.1 & 25.0 & 24.9 \\
\hline Capital expenditure and net lending & 6.8 & 6.2 & 5.1 & 5.9 & 5.3 & 5.0 & 4.9 & 4.8 & 4.3 & 4.0 & 3.8 & 3.6 & 3.7 \\
\hline Anguilla 2/ & 0.4 & 1.2 & 1.5 & 1.1 & 0.4 & 0.9 & 1.3 & 1.6 & 1.5 & 1.4 & 1.4 & 1.3 & 1.2 \\
\hline Antigua and Barbuda 3 / & 2.1 & 1.3 & 0.6 & 1.3 & 1.6 & 1.4 & 2.9 & 2.6 & 1.4 & 1.3 & 1.3 & 1.3 & 1.3 \\
\hline Dominica & 16.3 & 11.7 & 10.5 & 9.0 & 6.9 & 8.0 & 12.6 & 10.8 & 9.1 & 8.7 & 8.3 & 7.8 & 7.5 \\
\hline Grenada & 7.3 & 7.8 & 5.0 & 7.1 & 9.2 & 8.4 & 4.3 & 4.4 & 4.1 & 4.1 & 3.8 & 4.0 & 5.2 \\
\hline Montserrat & 19.9 & 16.2 & 23.5 & 45.8 & 26.5 & 16.5 & 12.2 & 15.1 & 13.0 & 10.1 & 10.7 & 9.4 & 8.3 \\
\hline St. Kitts and Nevis & 6.8 & 4.1 & 3.6 & 6.7 & 6.1 & 7.1 & 5.7 & 7.4 & 7.0 & 6.9 & 6.2 & 5.8 & 5.8 \\
\hline St. Lucia & 8.8 & 10.6 & 9.8 & 5.7 & 4.4 & 4.3 & 5.1 & 5.0 & 4.7 & 3.3 & 3.1 & 2.7 & 2.4 \\
\hline St. Vincent and the Grenadines & 4.5 & 4.0 & 1.8 & 7.8 & 6.4 & 5.0 & 3.4 & 2.4 & 2.9 & 3.6 & 3.7 & 3.7 & 3.7 \\
\hline Saving (current revenue less current expenditure) & -0.7 & -0.1 & -0.4 & 0.1 & 0.7 & 0.8 & -0.6 & 1.0 & 0.9 & 0.8 & 0.8 & 0.9 & 0.9 \\
\hline Anguilla 2/ & -7.0 & 3.3 & 0.6 & -0.6 & 0.6 & 0.4 & -36.2 & -0.3 & 0.3 & 1.1 & 1.7 & 2.4 & 2.9 \\
\hline Antigua and Barbuda 3/ & 0.2 & -2.6 & -0.6 & -2.2 & -3.4 & -7.0 & -3.4 & -0.4 & -0.6 & -0.7 & -0.9 & -1.0 & -1.1 \\
\hline Dominica & 3.3 & 2.3 & 2.3 & 3.0 & 0.2 & 4.9 & 10.4 & 9.6 & 7.2 & 6.6 & 6.4 & 6.5 & 6.8 \\
\hline Grenada & -0.4 & -0.8 & -2.0 & -1.6 & 0.5 & 3.9 & 3.1 & 2.4 & 2.8 & 3.1 & 3.5 & 3.7 & 3.8 \\
\hline Montserrat & -33.1 & -30.2 & -41.0 & -41.1 & -45.6 & -47.0 & -39.4 & -42.8 & -40.5 & -36.8 & -34.7 & -33.2 & -30.5 \\
\hline St. Kitts and Nevis & -3.4 & 2.5 & 5.0 & 11.8 & 12.6 & 11.4 & 5.5 & 3.0 & 3.3 & 2.2 & 2.3 & 2.3 & 2.3 \\
\hline St. Lucia & 1.3 & 1.7 & -1.5 & -1.9 & -0.7 & 0.3 & -0.4 & -1.2 & -1.5 & -1.9 & -2.1 & -2.5 & -2.8 \\
\hline St. Vincent and the Grenadines & -1.7 & -1.8 & -1.0 & -1.5 & 1.3 & 0.3 & 3.3 & 1.4 & 2.1 & 2.5 & 2.6 & 2.7 & 2.8 \\
\hline Primary balance & -0.7 & -0.4 & -0.2 & 0.1 & 1.3 & 2.1 & 0.9 & 2.2 & 2.3 & 2.3 & 2.4 & 2.4 & 2.3 \\
\hline Anguilla 2/ & -1.2 & 3.2 & 2.1 & 1.6 & 3.0 & 0.9 & -35.0 & 6.2 & 4.0 & 4.7 & 3.1 & 3.7 & 4.1 \\
\hline Antigua and Barbuda 3/ & 1.8 & -0.8 & 1.3 & -1.7 & -0.2 & -0.1 & 3.6 & 3.0 & 3.2 & 3.0 & 2.7 & 2.5 & 2.3 \\
\hline Dominica & -1.8 & -2.9 & -3.4 & -0.8 & -3.1 & 1.1 & 0.8 & 2.3 & 2.0 & 2.1 & 2.1 & 2.7 & 3.2 \\
\hline Grenada & -1.5 & -2.7 & -2.5 & -3.9 & -1.1 & 2.2 & 5.3 & 4.4 & 4.3 & 4.3 & 4.4 & 3.9 & 2.4 \\
\hline Montserrat & 2.3 & 7.7 & -7.0 & -17.0 & -6.1 & 21.6 & -0.3 & 7.2 & 4.2 & 5.7 & 4.8 & 4.7 & 4.9 \\
\hline St. Kitts and Nevis & -0.6 & 8.0 & 10.8 & 16.0 & 12.3 & 7.8 & 3.1 & -0.7 & -0.1 & -1.6 & -0.9 & -0.6 & -0.7 \\
\hline St. Lucia & -1.9 & -3.5 & -5.8 & -2.1 & 0.1 & 1.5 & 0.9 & 0.1 & 0.4 & 1.8 & 2.1 & 2.5 & 2.8 \\
\hline St. Vincent and the Grenadines & -0.9 & -1.2 & 0.4 & -3.7 & -0.7 & 0.1 & 3.2 & 3.1 & 3.3 & 3.0 & 3.0 & 3.0 & 3.0 \\
\hline Overall balance & -3.6 & -3.3 & -3.3 & -2.7 & -1.5 & -0.7 & -1.9 & -0.6 & -0.6 & -0.6 & -0.5 & -0.5 & -0.7 \\
\hline Anguilla 2/ & -2.7 & 2.1 & 0.9 & 0.4 & 1.9 & 0.0 & -36.4 & 4.5 & 2.3 & 3.1 & 1.7 & 2.4 & 2.9 \\
\hline Antigua and Barbuda 3/ & -0.3 & -2.9 & -1.0 & -3.5 & -2.8 & -2.6 & 1.0 & 0.4 & 0.5 & 0.3 & 0.0 & -0.2 & -0.4 \\
\hline Dominica & -3.4 & -4.4 & -5.4 & -2.8 & -4.7 & -0.9 & -1.2 & 0.3 & 0.1 & 0.1 & 0.3 & 0.8 & 1.4 \\
\hline Grenada & -3.6 & -5.2 & -5.9 & -7.3 & -4.7 & -1.2 & 2.4 & 2.2 & 2.4 & 2.6 & 2.9 & 2.5 & 1.2 \\
\hline Montserrat & 2.3 & 7.7 & -7.0 & -17.0 & -6.2 & 21.6 & -0.3 & 7.1 & 4.1 & 5.6 & 4.7 & 4.6 & 4.8 \\
\hline St. Kitts and Nevis & -7.3 & 1.8 & 4.9 & 12.1 & 9.5 & 5.7 & 1.4 & -2.4 & -1.7 & -3.2 & -2.6 & -2.3 & -2.3 \\
\hline St. Lucia & -4.9 & -6.6 & -9.3 & -6.0 & -3.7 & -2.6 & -3.9 & -4.9 & -4.9 & -3.9 & -3.9 & -3.9 & -3.9 \\
\hline St. Vincent and the Grenadines & -3.9 & -3.7 & -1.9 & -6.2 & -3.0 & -2.1 & 1.0 & 0.3 & 0.6 & 0.3 & 0.3 & 0.4 & 0.5 \\
\hline $\begin{array}{l}\text { Sources: Country authorities; and Fund staff estimate } \\
\text { 1/ Fiscal years for Dominica, Montserrat (since 2010) } \\
\text { 2/ An estimate of the bank resolution cost is included } \\
\text { 3/ An estimate of the bank resolution cost is included }\end{array}$ & $\begin{array}{l}\text { ctions. } \\
\text { ia. }\end{array}$ & & & & & & & & & & & & \\
\hline
\end{tabular}


Table 4. ECCU: Selected Public Sector Debt Indicators by Country, 2010-221

\begin{tabular}{|c|c|c|c|c|c|c|c|c|c|c|c|c|c|}
\hline & \multirow[b]{2}{*}{2010} & \multirow[b]{2}{*}{2011} & \multirow[b]{2}{*}{2012} & \multirow[b]{2}{*}{2013} & \multirow[b]{2}{*}{2014} & \multicolumn{2}{|c|}{ Prel. } & \multicolumn{6}{|c|}{ Proj, } \\
\hline & & & & & & 2015 & $2016^{-}$ & 2017 & 2018 & 2019 & 2020 & 2021 & 2022 \\
\hline \multicolumn{14}{|c|}{ (In percent of GDP) } \\
\hline Total public sector debt 2/ & 84.7 & 85.7 & 86.2 & 85.7 & 84.3 & 81.0 & 79.8 & 76.6 & 74.3 & 72.3 & 70.2 & 68.1 & 66.4 \\
\hline Anguilla 3/ & 32.5 & 29.2 & 30.9 & 30.4 & 24.1 & 24.6 & 47.0 & 40.0 & 33.8 & 29.7 & 25.4 & 21.4 & 18.0 \\
\hline Antigua and Barbuda 3/ & 90.0 & 91.6 & 86.4 & 94.8 & 102.7 & 99.1 & 92.7 & 87.9 & 85.0 & 82.4 & 80.2 & 78.3 & 75.3 \\
\hline Dominica & 66.8 & 69.7 & 72.4 & 80.1 & 82.2 & 82.9 & 82.7 & 80.1 & 77.8 & 75.7 & 73.5 & 70.9 & 68.0 \\
\hline Grenada & 96.9 & 100.7 & 103.3 & 108.1 & 101.8 & 91.7 & 83.4 & 71.8 & 65.8 & 60.4 & 54.9 & 49.8 & 46.3 \\
\hline Montserrat & 5.8 & 4.7 & 4.3 & 4.7 & 4.3 & 6.0 & 5.3 & 4.8 & 4.3 & 3.7 & 3.3 & 2.8 & 2.4 \\
\hline St. Kitts and Nevis & 156.5 & 146.6 & 137.9 & 101.1 & 81.4 & 70.6 & 65.6 & 62.7 & 60.0 & 58.0 & 55.8 & 52.7 & 52.4 \\
\hline St. Lucia & 62.8 & 67.4 & 74.5 & 77.2 & 78.1 & 77.8 & 82.9 & 85.6 & 88.5 & 90.9 & 93.3 & 95.5 & 97.7 \\
\hline St. Vincent and the Grenadines & 67.7 & 69.3 & 72.5 & 75.9 & 79.4 & 81.3 & 80.5 & 78.1 & 75.7 & 73.5 & 71.2 & 68.9 & 67.2 \\
\hline External debt 4/ & 42.5 & 43.2 & 42.2 & 45.7 & 45.8 & 43.1 & 42.7 & 40.2 & 38.4 & 36.9 & 35.4 & 33.7 & 32.1 \\
\hline Anguilla 3/ & 24.4 & 22.1 & 22.9 & 22.5 & 20.0 & 20.9 & 20.2 & 17.7 & 14.9 & 12.3 & 9.9 & 7.8 & 5.9 \\
\hline Antigua and Barbuda 3/ & 38.4 & 38.7 & 36.4 & 43.4 & 46.2 & 45.1 & 43.4 & 42.2 & 40.4 & 39.0 & 37.5 & 36.1 & 33.5 \\
\hline Dominica & 49.0 & 49.6 & 52.5 & 61.6 & 62.0 & 62.4 & 63.6 & 61.6 & 58.8 & 56.8 & 55.3 & 53.6 & 51.6 \\
\hline Grenada & 68.9 & 69.0 & 67.6 & 70.8 & 67.7 & 62.6 & 57.9 & 48.3 & 44.8 & 42.2 & 38.9 & 34.8 & 32.6 \\
\hline Montserrat & 5.6 & 4.5 & 4.2 & 4.0 & 3.6 & 5.3 & 4.6 & 4.1 & 3.6 & 3.1 & 2.7 & 2.3 & 1.9 \\
\hline St. Kitts and Nevis & 47.3 & 48.2 & 43.2 & 40.7 & 36.4 & 26.9 & 23.6 & 21.2 & 18.8 & 16.7 & 14.8 & 13.1 & 11.5 \\
\hline St. Lucia & 31.2 & 33.0 & 34.3 & 37.2 & 38.7 & 36.9 & 39.5 & 40.9 & 42.4 & 43.6 & 44.8 & 46.0 & 47.1 \\
\hline St. Vincent and the Grenadines & 40.8 & 43.1 & 40.5 & 42.3 & 45.3 & 43.2 & 47.3 & 44.5 & 41.6 & 38.5 & 35.6 & 32.8 & 30.2 \\
\hline Domestic debt & 42.2 & 42.5 & 44.0 & 40.0 & 38.5 & 37.9 & 37.1 & 36.4 & 35.9 & 35.4 & 34.8 & 34.3 & 34.2 \\
\hline Anguilla 3/ & 8.1 & 7.2 & 8.0 & 8.0 & 4.1 & 3.7 & 26.8 & 22.3 & 18.9 & 17.4 & 15.5 & 13.7 & 12.1 \\
\hline Antigua and Barbuda 3/ & 51.6 & 52.9 & 50.1 & 51.4 & 56.5 & 53.9 & 49.3 & 45.7 & 44.6 & 43.4 & 42.7 & 42.1 & 41.8 \\
\hline Dominica & 17.8 & 20.1 & 19.9 & 18.5 & 20.1 & 20.5 & 19.0 & 18.5 & 19.0 & 18.9 & 18.2 & 17.3 & 16.5 \\
\hline Grenada & 28.0 & 31.7 & 35.8 & 37.3 & 34.1 & 29.1 & 25.6 & 23.5 & 21.0 & 18.3 & 16.0 & 15.0 & 13.7 \\
\hline Montserrat & 0.3 & 0.2 & 0.1 & 0.7 & 0.7 & 0.7 & 0.7 & 0.7 & 0.6 & 0.6 & 0.6 & 0.6 & 0.5 \\
\hline St. Kitts and Nevis & 109.2 & 98.5 & 94.7 & 60.3 & 44.9 & 43.7 & 42.0 & 41.5 & 41.2 & 41.3 & 41.0 & 39.7 & 40.9 \\
\hline St. Lucia & 31.5 & 34.4 & 40.2 & 40.0 & 39.4 & 40.8 & 43.4 & 44.7 & 46.2 & 47.3 & 48.4 & 49.5 & 50.5 \\
\hline \multirow[t]{2}{*}{ St. Vincent and the Grenadines } & 27.0 & 26.1 & 32.0 & 33.5 & 34.1 & 38.0 & 33.1 & 33.5 & 34.1 & 35.0 & 35.6 & 36.1 & 37.0 \\
\hline & \multicolumn{13}{|c|}{ Implied interest rete contral arornment deht } \\
\hline Implied interest rate on central gove & & & & & & & & & & & & & \\
\hline Anguilla 3/ & 5.1 & 4.3 & 4.1 & 4.2 & 5.0 & 4.2 & 2.9 & 4.7 & 5.2 & 5.3 & 5.9 & 6.8 & 7.8 \\
\hline Antigua and Barbuda 3/ & 2.8 & 2.7 & 3.1 & 2.4 & 3.3 & 3.2 & 3.7 & 4.0 & 4.3 & 4.5 & 4.7 & 4.9 & 5.1 \\
\hline Dominica & 2.8 & 2.6 & 3.3 & 3.3 & 2.6 & 3.3 & 3.3 & 3.4 & 3.4 & 3.5 & 3.5 & 3.8 & 3.8 \\
\hline Grenada & 2.4 & 2.6 & 3.5 & 3.2 & 3.7 & 3.9 & 3.6 & 3.2 & 3.1 & 2.9 & 2.9 & 2.8 & 2.7 \\
\hline Montserrat & 2.4 & 2.2 & 2.0 & 1.6 & 1.6 & 0.7 & 0.6 & 1.1 & 1.3 & 1.4 & 1.6 & 1.8 & 1.9 \\
\hline St. Kitts and Nevis & 5.5 & 5.3 & 5.4 & 4.9 & 4.0 & 3.7 & 3.3 & 3.2 & 3.3 & 3.4 & 3.7 & 3.9 & 3.8 \\
\hline St. Lucia & 5.3 & 4.9 & 5.0 & 5.3 & 5.1 & 5.4 & 5.9 & 6.0 & 6.2 & 6.5 & 6.7 & 6.9 & 7.1 \\
\hline St. Vincent and the Grenadines & 5.3 & 4.0 & 3.9 & 3.9 & 3.4 & 3.0 & 3.0 & 4.0 & 3.9 & 4.2 & 4.2 & 4.2 & 4.2 \\
\hline Implied interest rates on central gov & & & & & & & & & & & & & \\
\hline Anguilla 3/ & 1.4 & 4.1 & 3.7 & 3.8 & 4.0 & 3.5 & 2.7 & 4.6 & 5.2 & 5.6 & 6.6 & 8.1 & 10.3 \\
\hline Antigua and Barbuda 3/5/ & 1.5 & 2.2 & 1.4 & 1.2 & 2.5 & 1.5 & 2.5 & 2.9 & 3.4 & 3.6 & 3.8 & 4.0 & 4.1 \\
\hline Dominica & 3.0 & 1.7 & 2.8 & 2.4 & 2.2 & 3.4 & 2.4 & 2.4 & 2.4 & 2.3 & 2.3 & 2.5 & 2.5 \\
\hline Grenada & 1.8 & 1.9 & 2.9 & 2.5 & 3.0 & 3.8 & 3.7 & 3.4 & 2.8 & 2.6 & 2.6 & 2.5 & 2.4 \\
\hline Montserrat & 1.6 & 2.1 & 1.6 & 2.1 & 2.1 & 0.6 & 0.6 & 0.6 & 0.6 & 0.6 & 0.7 & 0.7 & 0.7 \\
\hline St. Kitts and Nevis & 5.6 & 4.2 & 5.1 & 1.4 & 2.1 & 2.5 & 2.1 & 2.1 & 2.1 & 2.0 & 2.0 & 2.0 & 1.9 \\
\hline St. Lucia & 4.5 & 3.8 & 4.2 & 4.3 & 3.9 & 3.8 & 4.7 & 4.7 & 4.9 & 5.2 & 5.4 & 5.6 & 5.8 \\
\hline St. Vincent and the Grenadines 6/ & 3.1 & 3.0 & 3.2 & 2.6 & 2.3 & 2.2 & 1.9 & 2.6 & 2.8 & 2.9 & 2.9 & 2.8 & 2.8 \\
\hline Implied interest rates on central gov & & & & & & & & & & & & & \\
\hline Anguilla 3/ & $\ldots$ & 4.8 & 5.2 & 5.2 & 9.3 & 7.6 & 3.1 & 4.8 & 5.2 & 5.1 & 5.5 & 6.1 & 6.6 \\
\hline Antigua and Barbuda 3/5/ & 3.8 & 3.0 & 4.5 & 3.4 & 3.9 & 4.5 & 4.5 & 4.7 & 4.9 & 5.0 & 5.2 & 5.3 & 5.5 \\
\hline Dominica & 2.4 & 5.0 & 4.7 & 6.0 & 3.6 & 2.9 & 5.9 & 6.3 & 6.3 & 6.8 & 7.1 & 7.4 & 7.6 \\
\hline Grenada & 4.1 & 4.2 & 4.8 & 4.8 & 5.1 & 4.0 & 3.4 & 3.0 & 3.7 & 3.8 & 3.7 & 3.5 & 3.6 \\
\hline Montserrat & 6.3 & 2.5 & 7.2 & 0.9 & 0.9 & 0.9 & 0.9 & 3.0 & 3.7 & 4.4 & 5.0 & 5.6 & 6.1 \\
\hline St. Kitts and Nevis & 5.4 & 5.9 & 5.6 & 8.2 & 5.9 & 4.7 & 4.0 & 3.8 & 4.0 & 4.2 & 4.4 & 4.7 & 4.4 \\
\hline St. Lucia & 6.1 & 6.0 & 5.7 & 6.4 & 6.3 & 6.9 & 7.1 & 7.1 & 7.4 & 7.6 & 7.8 & 8.0 & 8.2 \\
\hline St. Vincent and the Grenadines 6/ & 9.3 & 6.3 & 4.7 & 5.9 & 5.1 & 4.1 & 4.7 & 6.1 & 5.4 & 5.9 & 6.0 & 6.0 & 6.1 \\
\hline $\begin{array}{l}\text { Sources: Country authorities; and Fur } \\
1 \text { 1/ Fiscal years for Dominica, Montser }\end{array}$ & & & & & & & & & & & & & \\
\hline 2/ In Anguilla and Antigua, the basel & nportant & cal cor & dation & imitme & hat lon & gnifica & $y$ the $d$ & $0-G D P$ & & & & & \\
\hline tio over the projection horizon. Ad & ucturing & & & 管 & act on & eDt $-t$ & SDP ratic & & & & & & \\
\hline 3/ An estimate of the bank resolution & illa, and 2 & 15 for $\mathrm{An}$ & nuga in $B$ & buda. & & & & & & & & & \\
\hline 4/ Includes external arrears. & & & & & & & & & & & & & \\
\hline 5 / Interest payments from 2009 are $o$ & & & & & & & & & & & & & \\
\hline $\begin{array}{l}\text { 6/ The increase (decrease) in implicit } \\
\text { external borrowing, resulting in a larg }\end{array}$ & 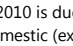 & $\begin{array}{l}\text { to the } p \\
\text { ernal) de }\end{array}$ & $\begin{array}{l}\text { ected re } \\
\text { outstan }\end{array}$ & $\begin{array}{l}\text { yment of } \\
\text { g. }\end{array}$ & omestic & t financ & & & & & & & \\
\hline
\end{tabular}




\begin{tabular}{|c|c|c|c|c|c|c|c|c|c|}
\hline \multicolumn{10}{|c|}{ Table 5. ECCU: Monetary Survey, 2010-18 } \\
\hline & & & & & & & Prelim. & Proj. & \\
\hline & 2010 & 2011 & 2012 & 2013 & 2014 & $2015^{-}$ & 2016 & 2017 & 2018 \\
\hline \multicolumn{10}{|c|}{ (In millions of EC dollars, end of period) } \\
\hline Net foreign assets & 2,148 & 2,053 & 2,865 & 3,481 & 4,960 & 6,533 & 7,400 & 7,950 & 8,435 \\
\hline Central bank & 2,498 & 2,718 & 3,031 & 3,150 & 3,804 & 4,206 & 4,557 & 4,805 & 5,052 \\
\hline Commercial banks (net) & -350 & -665 & -166 & 331 & 1,156 & 2,327 & 2,842 & 3,145 & 3,383 \\
\hline Assets & 3,200 & 3,864 & 4,045 & 4,206 & 4,940 & 5,905 & $\ldots$ & $\ldots$ & $\ldots$ \\
\hline Liabilities & $-3,550$ & $-4,529$ & $-4,212$ & $-3,874$ & $-3,784$ & $-3,578$ & $\ldots$ & $\ldots$ & $\ldots$ \\
\hline Net domestic assets & 10,252 & 10,709 & 10,709 & 10,429 & 10,085 & 9,125 & 8,382 & 8,159 & 8,118 \\
\hline Public sector credit, net & -91 & -134 & 63 & $-1,017$ & -286 & -755 & -986 & -983 & $-1,010$ \\
\hline Central government & 1,189 & 1,262 & 1,576 & 619 & 1,608 & 1,247 & 984 & 1,070 & 1,127 \\
\hline Other public sector & $-1,280$ & $-1,396$ & $-1,513$ & $-1,621$ & $-1,894$ & $-2,003$ & $-1,969$ & $-2,053$ & $-2,137$ \\
\hline Private sector credit, net & 12,601 & 12,773 & 13,334 & 12,980 & 12,377 & 11,841 & 11,146 & 11,213 & 11,366 \\
\hline (real terms) & 9,067 & 8,890 & 9,034 & 8,722 & 8,234 & 7,878 & 7,472 & 7,543 & 7,518 \\
\hline Other items (net) & $-2,258$ & $-1,930$ & $-2,688$ & $-1,195$ & $-2,006$ & $-1,960$ & $-1,779$ & $-2,071$ & $-2,238$ \\
\hline Broad money (M2) & 12,400 & 12,762 & 13,574 & 13,910 & 15,045 & 15,658 & 15,782 & 16,109 & 16,554 \\
\hline Money & 2,497 & 2,618 & 2,804 & 2,810 & 3,173 & 3,461 & 3,711 & 3,747 & 3,838 \\
\hline Currency in circulation & 834 & 876 & 896 & 926 & 991 & 1,024 & $\ldots$ & $\ldots$ & $\ldots$ \\
\hline Demand deposits & 1,881 & 1,984 & 2,170 & 2,188 & 2,457 & 2,697 & $\ldots$ & $\ldots$ & $\ldots$ \\
\hline Quasi-money & 9,903 & 10,143 & 10,770 & 11,312 & 11,872 & 12,197 & 12,070 & 12,362 & 12,715 \\
\hline Time deposits & 2,869 & 2,983 & 3,026 & 2,904 & 2,732 & 2,573 & & & \\
\hline Savings deposits & 5,282 & 5,484 & 5,969 & 6,400 & 6,787 & 7,002 & $\ldots$ & $\ldots$ & $\ldots$ \\
\hline Foreign currency deposits & 1,752 & 1,677 & 1,775 & 2,008 & 2,354 & 2,622 & $\ldots$ & $\ldots$ & $\ldots$ \\
\hline \multicolumn{10}{|c|}{ (Annual percentage change) } \\
\hline Net foreign assets & 13.4 & -4.4 & 39.6 & 21.5 & 42.5 & 31.7 & 13.3 & 7.4 & 6.1 \\
\hline Net domestic assets, o.w. & 0.1 & 4.5 & 0.0 & -2.6 & -3.3 & -9.5 & -8.1 & -2.7 & -0.5 \\
\hline Public sector credit, net & -123.8 & 47.6 & -146.8 & $-1,721.4$ & -71.9 & 164.5 & 30.5 & -0.3 & 2.7 \\
\hline Private sector credit, net & 2.2 & 1.4 & 4.4 & -2.7 & -4.6 & -4.3 & -5.9 & 0.6 & 1.4 \\
\hline Broad money (M2) & 2.2 & 2.9 & 6.4 & 2.5 & 8.2 & 4.1 & 0.8 & 2.1 & 2.8 \\
\hline NFA contribution & 2.1 & -0.8 & 6.4 & 4.5 & 10.6 & 10.5 & 5.5 & 3.5 & 3.0 \\
\hline NDA contribution & 0.1 & 3.7 & 0.0 & -2.1 & -2.5 & -6.4 & -4.7 & -1.4 & -0.3 \\
\hline Money & 1.4 & 4.8 & 7.1 & 0.2 & 12.9 & 9.1 & 7.2 & 1.0 & 2.4 \\
\hline NFA contribution & 13.9 & 8.8 & 12.0 & 4.2 & 23.3 & 12.7 & 10.1 & 6.7 & 6.6 \\
\hline NDA contribution & -12.4 & -3.9 & -4.9 & -4.0 & -10.4 & -3.6 & -2.9 & -5.7 & -4.2 \\
\hline Quasi-money & 2.4 & 2.4 & 6.2 & 5.0 & 5.0 & 2.7 & -1.0 & 2.4 & 2.9 \\
\hline \multicolumn{10}{|c|}{ (In percent of GDP) } \\
\hline Net foreign assets & 14.8 & 13.9 & 19.1 & 22.6 & 30.4 & 40.0 & 43.6 & 45.9 & 46.7 \\
\hline Net domestic assets, o.w. & 70.8 & 72.3 & 71.2 & 67.6 & 61.8 & 55.9 & 49.4 & 47.1 & 45.0 \\
\hline Public sector credit, net & -0.6 & -0.9 & 0.4 & -6.6 & -1.7 & -4.6 & -5.8 & -5.7 & -5.6 \\
\hline Private sector credit, net & 87.0 & 86.2 & 88.7 & 84.1 & 75.8 & 72.5 & 65.7 & 64.7 & 63.0 \\
\hline Broad money (M2) & 85.7 & 86.2 & 90.3 & 90.2 & 92.2 & 95.9 & 93.1 & 93.0 & 91.7 \\
\hline Money & 17.2 & 17.7 & 18.6 & 18.2 & 19.4 & 21.2 & 21.9 & 21.6 & 21.3 \\
\hline Quasi-money & 68.4 & 68.5 & 71.6 & 73.3 & 72.7 & 74.7 & 71.2 & 71.4 & 70.4 \\
\hline \multicolumn{10}{|l|}{ Interest rates (percent per year) } \\
\hline ECCB policy rate & 6.50 & 6.50 & 6.50 & 6.50 & 6.50 & 6.50 & 6.50 & & \\
\hline US policy rate & 0.125 & 0.125 & 0.125 & 0.125 & 0.125 & 0.135 & 0.386 & $\ldots$ & $\ldots$ \\
\hline Time deposit rate & 4.51 & 4.17 & 4.34 & 4.06 & 3.60 & 2.77 & 2.48 & $\ldots$ & $\ldots$ \\
\hline Demand deposit rate & 0.74 & 0.68 & 0.74 & 0.58 & 0.48 & 0.35 & 0.24 & $\ldots$ & $\ldots$ \\
\hline Weighted average lending rate & 9.48 & 9.53 & 8.91 & 8.94 & 8.92 & 8.67 & 8.53 & & \\
\hline
\end{tabular}




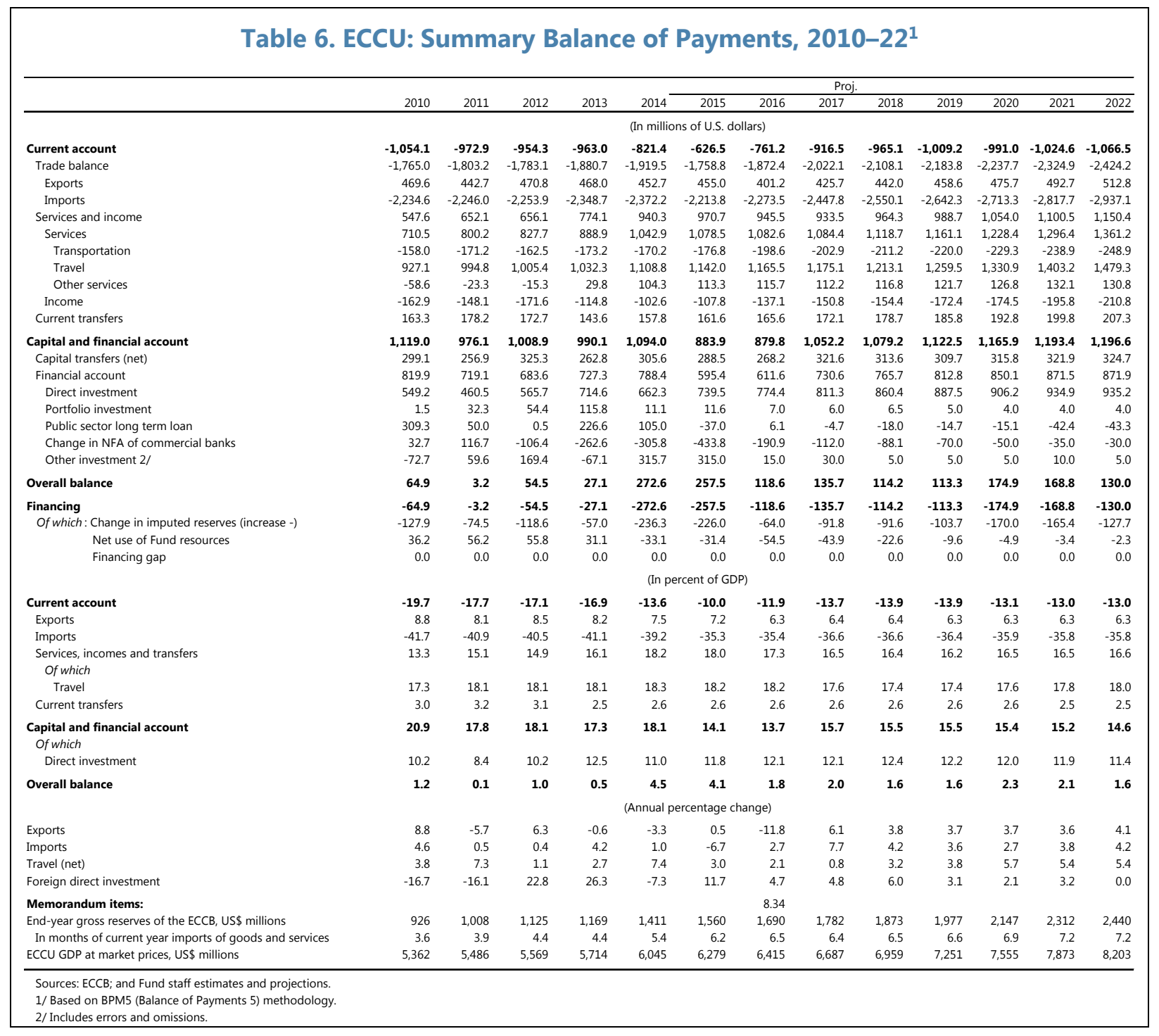


Table 7. ECCU: Selected Labor Market Indicators ${ }^{1}$

Total Population (y-o-y \% change)

Antigua and Barbuda

Dominica

$\begin{array}{rrr}1.7 & 1.1 & 1.1 \\ 0.0 & -0.1 & 0.0 \\ 0.2 & 0.3 & 0.4 \\ 1.5 & 1.2 & 1.2 \\ 1.2 & 1.2 & 0.6 \\ 0.0 & 0.1 & 0.1\end{array}$

Grenada

St. Kitts and Nevis

St. Lucia

St. Vincent and the Grenadines

0.2

Antigua and Barbuda

Dominica

Grenada

St. Kitts and Nevis

St. Lucia

St. Vincent and the Grenadines

\section{Unemployment rate (\%)}

Antigua and Barbuda

Dominica

Grenada

St. Kitts and Nevis

St. Lucia

St. Vincent and the Grenadines

Wages (EC\$, annual average)

Antigua and Barbuda

Dominica

Grenada

St. Kitts and Nevis

St. Lucia

St. Vincent and the Grenadines

Public Sector Wages (EC\$, annual average)

Antigua and Barbuda

Dominica

Grenada

St. Kitts and Nevis

St. Lucia

St. Vincent and the Grenadines
1.3

1.1

0.9

8.4

11.0

9.9

5.1

16.5

21.1

24,734

6

...

12,779

10,868

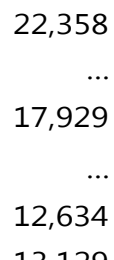

13,129
4.1

13.9

24.9

5.1

15.8

18.8

0.6

0.6

...

0.5

0.5

18.8

29,351

13,807

20,019

23,089

18,491

16,124

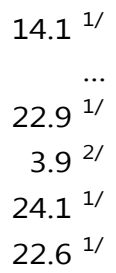

$22.6^{1 /}$

Sources: WEO, World Bank, WDI, National Authorities (censuses and poverty assessments); and IMF staff calculations.

1/ 2015

2/ 2013

$3 / 2014$

4/ 2012 


\section{Annex I. Implementation of Previous Staff Advice}

\begin{tabular}{|c|c|c|}
\hline \multicolumn{2}{|r|}{$\begin{array}{l}\text { Recommendations from the } 2016 \\
\text { Common Policies Discussion }\end{array}$} & Policy Actions \\
\hline \multicolumn{3}{|c|}{ Further Improve the Health and Stability of the Financial System } \\
\hline \multicolumn{2}{|c|}{ Operationalize the ECAMC } & $\begin{array}{l}\text { The opening of the ECAMC is now expected in short } \\
\text { order. Six of the eight jurisdictions have paid their } \\
\text { capital contributions. The Board of Directors is } \\
\text { confirmed and has met twice. A CFO, head of assets } \\
\text { and legal officer have been recruited and the } \\
\text { recruitment of a CEO is under way. The board } \\
\text { received an orientation workshop by the IMF and } \\
\text { World Bank in early April } 2017 \text {. }\end{array}$ \\
\hline \multicolumn{2}{|c|}{$\begin{array}{l}\text { Reform alien land holding laws in some jurisdictions } \\
\text { (e.g., Anguilla) to facilitate the ECAMC's sale of the } \\
\text { assets. }\end{array}$} & $\begin{array}{l}\text { Limited progress. Due to constitutional issues, the } \\
\text { ECAMC Law does not provide for exclusion from the } \\
\text { Alien Landholding Law, as originally intended. In } \\
\text { Grenada, OECS citizens purchasing land must obtain } \\
\text { a non-citizen land holding license, but there is no } \\
\text { license fee. However, they are required to pay a } \\
\text { property transfer tax of } 10 \text { percent of the property's } \\
\text { market value. In St. Kitts and Nevis, cabinet swiftly and } \\
\text { frequently approves alien land holding. }\end{array}$ \\
\hline \multicolumn{3}{|c|}{$\begin{array}{l}\text { Order corrective actions, including capital calls, as } \\
\text { soon as possible from undercapitalized-but-viable } \\
\text { banks identified in the asset quality reviews }\end{array}$} \\
\hline i. & Update the 2014 asset quality reviews & No direct action has been taken. \\
\hline & $\begin{array}{l}\text { Undercapitalized but viable banks to submit } \\
\text { sound capitalization plans to the ECCB. } \\
\text { Unviable banks to exit the market in an } \\
\text { orderly fashion. }\end{array}$ & $\begin{array}{l}\text { While the } 2014 \text { AQRs have not been updated, section } \\
44 \text { (1) of the new Banking Act requires a minimum } \\
\text { capital of EC } \$ 20 \text { million for commercial banks. This } \\
\text { represents an augmentation from EC } \$ 5 \text { million under } \\
\text { the previous Banking Act. Non-compliant banks } \\
\text { continue working towards compliance by the } \\
\text { statutory deadlines. Capital augmentation plans were } \\
\text { submitted by banks, as required. }\end{array}$ \\
\hline & $\begin{array}{l}\text { Banks carry out their plans by a fixed } \\
\text { deadline }\end{array}$ & $\begin{array}{l}\text { Following the commencement of the Banking Act, } \\
\text { banks have either implemented or altered their plans } \\
\text { to satisfy the stipulated capital requirements. }\end{array}$ \\
\hline & $\begin{array}{l}\text { Noncompliant viable banks merge with or } \\
\text { are acquired by other banks }\end{array}$ & $\begin{array}{l}\text { These remain some of the options for } \\
\text { undercapitalized banks and will be pursued if } \\
\text { required. }\end{array}$ \\
\hline
\end{tabular}




\begin{tabular}{|c|c|c|}
\hline \multicolumn{2}{|r|}{$\begin{array}{l}\text { Recommendations from the } 2016 \\
\text { Common Policies Discussion }\end{array}$} & Policy Actions \\
\hline v. & $\begin{array}{l}\text { ECCB to explore bank merger options that } \\
\text { would reduce concentration and liquidity } \\
\text { risks while improving profitability prospects. }\end{array}$ & $\begin{array}{l}\text { The capital adequacy, corporate governance, } \\
\text { concentration and liquidity risks, and profitability of } \\
\text { the resulting institution are some of the factors that } \\
\text { will be properly assessed prior to } \\
\text { applying/approving the merger option. }\end{array}$ \\
\hline \multicolumn{2}{|c|}{ Enhance supervisory processes with respect to: } & \\
\hline i. & Loan classification & $\begin{array}{l}\text { Drafting of the Treatment of Assets Standards } \\
\text { commenced in } 2014 \text { with input from the IMF and } \\
\text { CARTAC TA. The standards were subsequently } \\
\text { updated with comments received from the industry. } \\
\text { They are being finalized for submission to the } \\
\text { Institute of Chartered Accountants of the Eastern } \\
\text { Caribbean and the bankers' associations in each } \\
\text { member territory for final comments. The targeted } \\
\text { date for implementation is December } 2017 \text {. }\end{array}$ \\
\hline & Collateral valuation & $\begin{array}{l}\text { The project plan is at an advanced stage of } \\
\text { completion and is expected to form the basis of the } \\
\text { proposal to the Monetary Council at its July } 2017 \\
\text { meeting with its adoption and implementation } \\
\text { targeted by 2018Q1. Bank examiners will continue to } \\
\text { receive training in collateral valuation. }\end{array}$ \\
\hline & On- and off-site inspections & $\begin{array}{l}\text { The enhanced risk based supervisory framework is } \\
\text { being further developed with IMF TA. This includes } \\
\text { the approach to risk-based supervision, streamlining } \\
\text { the onsite examination process, surveillance and } \\
\text { onsite examination reports, and developing } \\
\text { supervisory manuals. Completion is expected by end- } \\
\text { June } 2018 \text {. }\end{array}$ \\
\hline & Implementation of Basel II & $\begin{array}{l}\text { The ECCB is currently receiving TA from CARTAC in } \\
\text { this area. This includes technical advice, training and } \\
\text { mentoring staff and assisting with enhancements to } \\
\text { the risk-based supervisory framework and Basel II } \\
\text { implementation. With CARTAC assistance, an initial } \\
\text { roadmap for implementation is being finalized. A } \\
\text { suite of draft Prudential Standards were submitted to } \\
\text { the banking sector for comments by August } 2016 \text { and } \\
\text { are currently being finalized. }\end{array}$ \\
\hline
\end{tabular}




\begin{tabular}{|c|c|}
\hline $\begin{array}{l}\text { Recommendations from the } 2016 \text { Common } \\
\text { Policies Discussion }\end{array}$ & Policy Actions \\
\hline $\begin{array}{l}\text { Safeguards Assessment: Reassign the internal audit } \\
\text { department's operational duties to other departments } \\
\text { to address conflict of interest issues. }\end{array}$ & $\begin{array}{l}\text { The roles of Compliance and Risk Management were } \\
\text { removed from the Internal Audit Department in June } \\
\text { and September 2015, respectively. The Compliance } \\
\text { function now resides in the Accounting Department. An } \\
\text { Office of Risk Management was established in the } \\
\text { Governor's Immediate Office and a Chief Risk Officer } \\
\text { was appointed on } 1 \text { September } 2015 \text { to oversee the } \\
\text { implementation of an Enterprise Risk Management } \\
\text { Framework at the Bank. The Internal Audit Department } \\
\text { is now primarily focused on Assurance, as reflected in } \\
\text { the revised work program }\end{array}$ \\
\hline $\begin{array}{l}\text { Eliminate the minimum saving deposit rate } \\
\text { or restrict its applicability to small saving deposits }\end{array}$ & $\begin{array}{l}\text { In } 2015 \text {, the Monetary Council reduced the minimum } \\
\text { savings rate from } 3.0 \text { percent to } 2.0 \text { percent, based on } \\
\text { the expectations of subsequent declines in the lending } \\
\text { rates, which decline on average by only } 25 \text { basis points } \\
\text { in } 2016 \text {. The impact on credit growth has been muted; } \\
\text { banks continue to limit their risk exposure with tighter } \\
\text { credit standards, despite the lowered cost of funds. } \\
\text { Eliminating the minimum savings rate is not currently } \\
\text { being considered by the ECCB. }\end{array}$ \\
\hline \multicolumn{2}{|l|}{$\begin{array}{l}\text { Implement other structural reforms that would } \\
\text { facilitate improving access to credit and reducing } \\
\text { lending rates }\end{array}$} \\
\hline $\begin{array}{l}\text { i. Draft regional foreclosure bill that aims } \\
\text { to reduce the time and cost of resolving } \\
\text { problem loans and securing collateral }\end{array}$ & $\begin{array}{l}\text { The ECCB commissioned a very comprehensive report } \\
\text { recommending reforms in land registration systems } \\
\text { and foreclosure practices and procedures. These have } \\
\text { been submitted for the consideration and approval of } \\
\text { member governments. The governments of St Vincent } \\
\text { and the Grenadines, Antigua and Barbuda, Grenada, } \\
\text { Dominica, and Anguilla have approved the } \\
\text { recommendations. The ECCB has identified a legislative } \\
\text { drafting consultant to assist with the drafting of } \\
\text { appropriate legislation and has contacted the World } \\
\text { Bank for assistance with this project following approval } \\
\text { by member governments. }\end{array}$ \\
\hline ii. Establish a regional credit bureau & $\begin{array}{l}\text { Under way. Last February, the Monetary Council } \\
\text { endorsed the proposed credit reporting legislative } \\
\text { package, with parliamentary approval in respective } \\
\text { member territories expected by September } 2017 \text {. Once } \\
\text { the legislation is in effect in each member territory, an } \\
\text { operator will be selected and the bureau } \\
\text { operationalized. The authorities are receiving TA from } \\
\text { the IFC. }\end{array}$ \\
\hline
\end{tabular}




\begin{tabular}{|c|c|c|}
\hline & $\begin{array}{l}\text { ecommendations from the } 2016 \\
\text { Common Policies Discussion }\end{array}$ & Policy Actions \\
\hline \multicolumn{3}{|c|}{ Mitigate the risk of withdrawal of correspondent banking relationships } \\
\hline \multicolumn{3}{|c|}{ Strengthen regulatory frameworks } \\
\hline i. & Strong governance of CBI programs & $\begin{array}{l}\text { Regional vetting policy and procedures are being } \\
\text { discussed by a committee of regional institutions } \\
\text { charged with the issue by the OECS Authority. In line } \\
\text { with the October } 2016 \text { decision by the Monetary } \\
\text { Council, the ECCB has encouraged other ECCU } \\
\text { countries to publish information on their programs as } \\
\text { in Grenada; publication templates were submitted to } \\
\text { the countries. }\end{array}$ \\
\hline & $\begin{array}{l}\text { Effective implementation of AML/CFT } \\
\text { standards }\end{array}$ & $\begin{array}{l}\text { The ECCB is to assume AML/CFT responsibilities for } \\
\text { all institutions licensed under the Banking Act, as } \\
\text { decided by the Monetary Council in July 2016. The } \\
\text { ECCB is receiving TA from the U.S. Department of the } \\
\text { Treasury. A needs assessment was completed in } \\
\text { March 2017. Pending the legislative transfer of the } \\
\text { authority for AML/CFT to the ECCB, the ECCB and the } \\
\text { relevant national regulators have commenced efforts } \\
\text { towards the establishment of a Memorandum of } \\
\text { Understanding for cooperation in information } \\
\text { sharing and the conduct of AML/CFT assessments for } \\
\text { institutions licensed under the Banking Act. }\end{array}$ \\
\hline & $\begin{array}{l}\text { Accelerate CARTAC-supported Basel II } \\
\text { implementation and risk-based supervision } \\
\text { in banking and non-banking sector }\end{array}$ & $\begin{array}{l}\text { The ECCB established a financial stability team in June } \\
2016 \text { to conduct macro-prudential surveillance and } \\
\text { provide a bi-annual assessment of financial stability. }\end{array}$ \\
\hline & $\begin{array}{l}\text { Increase information sharing with } \\
\text { correspondent banks }\end{array}$ & $\begin{array}{l}\text { Regional national banks have registered on the SWIFT } \\
\text { KYC Registry Portal, accessible by correspondent } \\
\text { banks. }\end{array}$ \\
\hline \multicolumn{3}{|c|}{ Strengthen fiscal policy } \\
\hline \multicolumn{2}{|c|}{$\begin{array}{l}\text { Pass national fiscal responsibility legislation (FRA) to } \\
\text { enshrine the regional debt target and specify fiscal } \\
\text { rules }\end{array}$} & $\begin{array}{l}\text { Only Grenada and Anguilla have FRA. The ECCB is } \\
\text { encouraging other member states to adopt FRA as } \\
\text { well. }\end{array}$ \\
\hline
\end{tabular}




\begin{tabular}{|c|c|c|}
\hline \multicolumn{2}{|r|}{$\begin{array}{l}\text { Recommendations from the } 2016 \\
\text { Common Policies Discussion }\end{array}$} & \multirow{2}{*}{$\begin{array}{l}\text { Policy Actions } \\
\text { ECCU finance ministers have agreed to present their } \\
\text { medium-term fiscal frameworks and discuss interim } \\
\text { debt targets for } 2020 \text { and } 2025 \text { at the ECCB's } \\
\text { Monetary Council on July } 2017 \text {. }\end{array}$} \\
\hline i. & $\begin{array}{l}\text { Articulate medium-term fiscal adjustment } \\
\text { strategies in the } 2017 \text { budgets, focused on } \\
\text { primary balance targets excluding CBI } \\
\text { revenues. }\end{array}$ & \\
\hline \multicolumn{2}{|c|}{$\begin{array}{l}\text { Internalize the expected costs of natural disasters in } \\
\text { the macro fiscal frameworks, including building } \\
\text { necessary buffers }\end{array}$} & \\
\hline i. & $\begin{array}{l}\text { Provide for savings of } 1 \text { percent of GDP per } \\
\text { year to buffers natural disasters. }\end{array}$ & $\begin{array}{l}\text { Most countries (Dominica) have set up saving funds } \\
\text { for natural disasters or are in the process of doing so } \\
\text { (St. Kitts and Nevis). }\end{array}$ \\
\hline ii. & $\begin{array}{l}\text { Include escape clauses in fiscal rules to } \\
\text { suspend the rules temporarily in the event } \\
\text { of a natural disaster }\end{array}$ & $\begin{array}{l}\text { Only Grenada has an escape clause for natural } \\
\text { disasters. }\end{array}$ \\
\hline \multicolumn{2}{|c|}{ Improve the overall PFM framework } & \\
\hline i. & $\begin{array}{l}\text { Accounting practices to include a broader } \\
\text { fiscal perimeter }\end{array}$ & Limited progress. \\
\hline ii. & $\begin{array}{l}\text { Save a significant portion of CBI resources } \\
\text { to a fund to address natural disaster shocks } \\
\text { and finance disaster resilient infrastructure. }\end{array}$ & $\begin{array}{l}\text { Most countries (Dominica, have set up saving funds } \\
\text { for natural disasters or are in the process of doing it. }\end{array}$ \\
\hline iii. & $\begin{array}{l}\text { Funding capital projects using CBI resources } \\
\text { requires rigorous project evaluation and } \\
\text { selection and sufficient resources to finance } \\
\text { the project until completion (to avoid } \\
\text { contingent liabilities for the government) }\end{array}$ & $\begin{array}{l}\text { While there is limited progress in some countries } \\
\text { (Annex IV), in Dominica the Public Sector Investment } \\
\text { Plan explicitly accounts for the use of available CBI } \\
\text { deposits as a source of financing, including in a } \\
\text { three-year projection. Projects account for resilience } \\
\text { against natural disasters. }\end{array}$ \\
\hline & $\begin{array}{l}\text { Improve capacity to design and manage } \\
\text { PSIPs }\end{array}$ & Limited progress (Annex IV). \\
\hline \multicolumn{2}{|c|}{$\begin{array}{l}\text { Adopt a comprehensive governance framework to } \\
\text { mitigate increased risks from CBI programs }\end{array}$} & \\
\hline i. & $\begin{array}{l}\text { Develop a regionally accepted set of } \\
\text { principles and code of conduct that would } \\
\text { set regional standards }\end{array}$ & $\begin{array}{l}\text { Regional vetting policy and procedures are being } \\
\text { discussed by a committee of regional institutions. }\end{array}$ \\
\hline ii. & $\begin{array}{l}\text { Rigorous due diligence process for } \\
\text { applicants }\end{array}$ & $\begin{array}{l}\text { All countries with CBI programs use independent } \\
\text { regional and international service providers for due } \\
\text { diligence. }\end{array}$ \\
\hline
\end{tabular}




\begin{tabular}{|c|c|c|}
\hline \multicolumn{2}{|r|}{$\begin{array}{c}\text { Recommendations from the } 2016 \\
\text { Common Policies Discussion }\end{array}$} & Policy Actions \\
\hline iii. & $\begin{array}{l}\text { Publish and subject to financial audits: } \\
\text { number of citizenships granted; revenue } \\
\text { earned; and use }\end{array}$ & $\begin{array}{l}\text { Grenada publishes information on its program; the } \\
\text { ECCB has encouraged the other countries to do the } \\
\text { same in October 2016; publication templates were } \\
\text { submitted to the countries. }\end{array}$ \\
\hline iv. & $\begin{array}{l}\text { Publish and subject to financial audits: } \\
\text { number of citizenships granted; revenue } \\
\text { earned; and use }\end{array}$ & $\begin{array}{l}\text { Grenada publishes information on its program; the } \\
\text { ECCB has encouraged the other countries to do the } \\
\text { same in October 2016; publication templates were } \\
\text { submitted to the countries. }\end{array}$ \\
\hline \multicolumn{3}{|c|}{ Enhance Competitiveness and Potential Growth } \\
\hline \multicolumn{2}{|c|}{ Implement national plans to diversify energy sources } & $\begin{array}{l}\text { Progress has been made, but there are delays } \\
\text { relative to the national targets. Dominica and St. } \\
\text { Vincent and the Grenadines are investing in } \\
\text { geothermal electricity to replace all or most diesel } \\
\text { generation. Projects are targeted for completion by } \\
\text { end- } 2018 \text {. }\end{array}$ \\
\hline \multicolumn{2}{|c|}{$\begin{array}{l}\text { Continue to move forward with regional } \\
\text { collaboration }\end{array}$} & \\
\hline i. & Develop a single domestic space & $\begin{array}{l}\text { Agreement was reached on the guidelines for the } \\
\text { free circulation of goods regime and a draft bill on } \\
\text { the free circulation of goods is being reviewed by } \\
\text { OECS member states. OECS nationals are free to } \\
\text { work in any ECCU country without work permits and } \\
\text { given indefinite stay. The next step will focus on } \\
\text { consolidation the regime to include portability of } \\
\text { social security benefits and fully implement the } \\
\text { OECS contingent rights policy. }\end{array}$ \\
\hline ii. & $\begin{array}{l}\text { Identify systems for harmonized border } \\
\text { management }\end{array}$ & Limited progress. \\
\hline iii. & Visitors to move freely within the region & Limited progress. \\
\hline iv. & Address issues with the regional airline & $\begin{array}{l}\text { In November 2016, the OECS Economic Affairs } \\
\text { Council approved a Regional Air Services Agreement } \\
\text { on the harmonization of air services in the OECS. The } \\
\text { agreement is to be considered by the Heads of } \\
\text { government. }\end{array}$ \\
\hline v. & $\begin{array}{l}\text { Implement single regional regulatory } \\
\text { authority for non-banks }\end{array}$ & $\begin{array}{l}\text { The Eastern Caribbean Financial Services } \\
\text { Commission has completed the initial stage of the } \\
\text { process, including public consultations on draft } \\
\text { legislation. A revised plan for the next phases is } \\
\text { expected to be approved soon. }\end{array}$ \\
\hline
\end{tabular}




\begin{tabular}{|c|c|c|}
\hline \multicolumn{2}{|c|}{$\begin{array}{c}\text { Recommendations from the } 2016 \\
\text { Common Policies Discussion }\end{array}$} & Policy Actions \\
\hline \multicolumn{3}{|c|}{$\begin{array}{l}\text { Adopt policies to reduce unit labor costs and boost } \\
\text { employment }\end{array}$} \\
\hline i. & $\begin{array}{l}\text { Better align wage growth with } \\
\text { productivity growth }\end{array}$ & Limited progress. \\
\hline ii. & Improve labor market flexibility & $\begin{array}{l}\text { Some attempts to introduce personnel shifts in } \\
\text { hotels and port operations. }\end{array}$ \\
\hline & Control public wage growth & $\begin{array}{l}\text { Grenada has developed a public service reform } \\
\text { strategy to be implemented in 2017-2019. Wage } \\
\text { freezes and attrition policies are still in effect in } \\
\text { some countries (see Annex III). }\end{array}$ \\
\hline & Strengthen labor-training programs & $\begin{array}{l}\text { Some programs are being revaluated and reformed, } \\
\text { such as in St. Kitts and Nevis. }\end{array}$ \\
\hline \multicolumn{3}{|c|}{ Improve macroeconomic statistics } \\
\hline Strengt & labor market statistics & $\begin{array}{l}\text { St. Vincent and the Grenadines published the results } \\
\text { of its } 2015 \text { Labour Market Survey. }\end{array}$ \\
\hline Ensure & istency of CBI flows with BPM6 & $\begin{array}{l}\text { A survey form prepared for BPM } 6 \text { is administered in } \\
\text { each country for the compilation of the BOP, which } \\
\text { entities use to report on receipts and payments of } C B \text { I } \\
\text { flows. }\end{array}$ \\
\hline
\end{tabular}




\section{Annex II. Citizenship-By-Investment Programs ${ }^{1}$}

The number of $C B I$ programs has surged in recent years on the back of soaring demand for secondary citizenships and the advantages of these programs for small island states. This has yielded substantial inflows of $C B I$ revenues in some countries, increasing their reliance on this volatile and unpredictable source. The success of programs with lower required contributions indicates intensified regional competition pointing to a "race to the bottom". To fend off external risks and foster program integrity and transparency, the ECCU is considering a regional approach to promote best practices, achieve economies of scale, and stop revenue erosion. Given the volatile and unpredictable nature of these receipts, priority should be given to using them for debt reduction, investment in key infrastructure and climate change adaptation, and building fiscal buffers.

\section{The launch of new citizenship programs in recent years has intensified competition,} creating pressure to ease conditions. After peaking in 2014, the demand for the citizenship program in St. Kitts and Nevis has continued to weaken, and started declining in Antigua and Barbuda in 2016. This reduction in CBI revenues, however, was largely offset by the surge experienced in Dominica owing to very competitive conditions and extensive outreach activities. Dominica's promotion, marketing, and outreach efforts during FY2015/16 amounted to 1.1 percent of GDP. Most of Dominica's CBI inflows, however, were recorded offbudget, and transferred to budget only as needed. Total inflows to Grenada held up in 2016, although the share of applicants interested in NTF option exceeded the

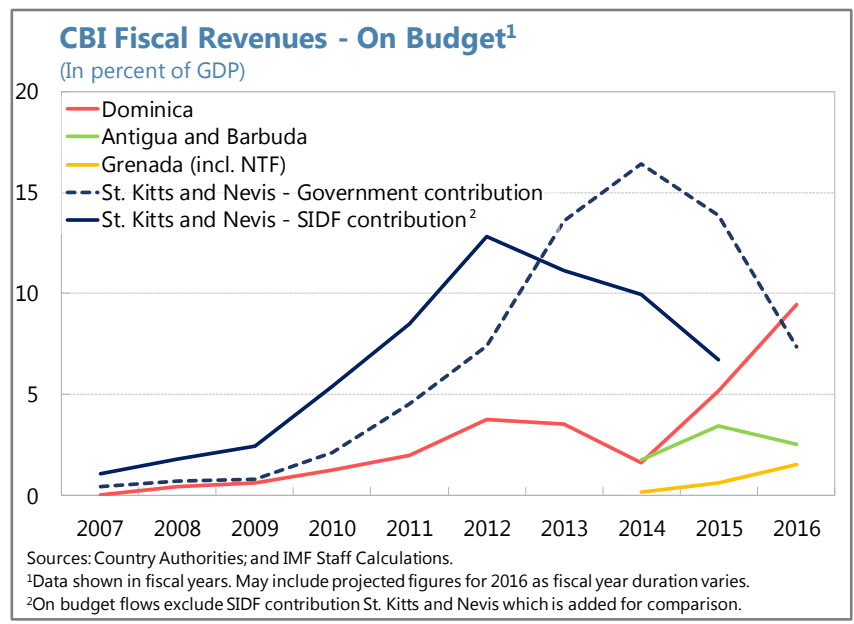
number of real estate applicants. The newly established program in St. Lucia met only limited success in its first year of operations, owing to its relative high pricing and political uncertainty in an election year. ${ }^{2}$

\section{Until now, CBI revenues have largely been used for general budget financing, debt} consolidation, and reconstruction after natural disasters. In Antigua and Barbuda, for instance, these resources have been used for debt servicing and general financing purposes, with a portion of funds - largely off-budget - used to support the social security system and state-owned enterprises. In Grenada, in accordance with the legislation, funds have been used to pay budgetary

\footnotetext{
${ }^{1}$ Prepared by Alla Myrvoda

2 During the first year of operations, six applications were approved under the real estate option, but none of them had reached investment stage by end-2016; fourteen applications were accepted under the donation option for a total of USD 1.4 million; and five applicants were approved under the bond option for USD 2.7 million. No interest was shown in the enterprise investment option.
} 
arrears, accumulate savings in the Contingency Fund, and investment projects. In St. Kitts and Nevis, revenues have contributed to funding a broad spectrum of expenditures, including social programs and grants, but a large part (about 38\% of GDP) was saved in bank deposits to establish the Growth Resilience Fund, as recommended by staff. In Dominica, CBI receipts were largely used to service and consolidate debt, finance infrastructure rehabilitation after storm Erika, and fund employment programs (see box). All countries have or intend to set up a sovereign wealth fund to save the proceeds from the citizenship program and use them to finance capital projects and debt repurchase.

\section{The Use of CBI Revenues in Dominica}

Interest in Dominica's CBI program has gained momentum, reflecting aggressive outreach and competitive conditions. CBI-generated revenues (gross of CBI-related expenses) reached an estimated 19 percent of GDP in FY2015/16.

\section{The use of CBI funds has largely targeted debt reduction, post-Erika reconstruction and}

infrastructure rehabilitation. ${ }^{1}$ Of the revenues generated in FY2015/16, 7 percent of GDP was used and 12 percent was deposited in the government's bank accounts. Of the amount spent, only 5 percent of GDP utilized in FY2015/16 was reflected in the central government budget, and 2 percent accrued directly to state-owned enterprises. Concerning the composition of spending, the largest share was used to consolidate and service debt (3.2 percent of GDP). Spending on public works (1.8 percent) targeted emergency infrastructure works at the Douglas Charles Airport and reconstruction and rehabilitation of roads and bridges post-Erika. With unemployment rising in the aftermath of the disaster, some inflows (0.7 percent of GDP) were

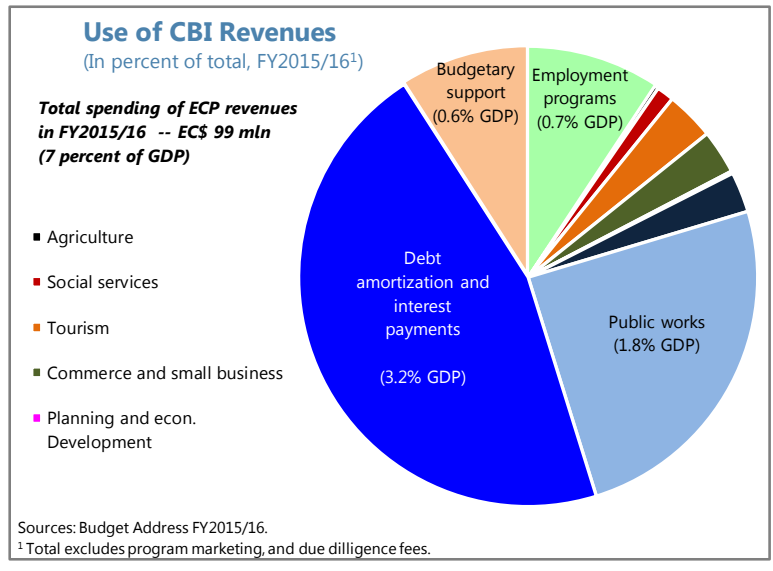
used to finance the National Employment program. The remaining funds were spent on social services, agriculture, tourism, housing, and commercial.

1/ On August 27, 2015, Dominica was hit by Tropical Storm Erika, resulting in loss of life and substantial damage to crops and physical infrastructure. The damage was estimated at US\$483 million or 96 percent of GDP, of which 65 percent are attributed to the public-sector reconstruction costs. 


\section{There are early signs of a "race to the}

bottom". To expand hotel construction, Dominica

amended its CBI program requirements by lowering the government fee of the real estate investment option. To enhance the program's competitiveness and revenue, St. Lucia has substantially eased accessibility to the citizenship program (see table). ${ }^{3}$ The authorities expect that these changes will improve the appeal of St. Lucia's program and boost applications and revenues. While this decision aligns St. Lucia's citizenship program with Dominica's, and may therefore generate additional demand, it is unlikely that CBI revenues in the former will become as important a source of revenue as in the latter owing to the much larger size of the St. Lucian economy.

\section{The demand for citizenship programs is susceptible to exogenous shocks independent} of the governments' control, making CBI inflows volatile and unpredictable. While the passport is the underlying asset, it is the ability to access other countries visa-free (or with limited hassle if visa is required) that is important to potential applicants. Thus, any potential change in advanced countries' migration policies poses a significant risk to the appeal of the passport and the demand for the CBI program. In the current complex global political and economic environment, the uncertainty surrounding future CBI inflows becomes even more acute, making budget planning more difficult.

\section{The authorities are considering a regional approach to CBI programs, which seems} best to reduce costs, increase revenues, and reduce reputational risks. To establish a stronger regulatory framework and promote collaboration on due diligence, the Citizenship-by-Investment Programs Association was formed in 2015. Moreover, the authorities of ECCU countries have recently granted to the Organization of Eastern Caribbean States (OECS) the mandate to coordinate regional cooperation on CBI programs. Joint management of CBI applications would yield economies of scale and reduce costs. A regional approach would prevent a race to the bottom, which reduces revenues. It would also ensure the adoption of best practices across the region, promoting information sharing and transparency, and preventing applicants who fail due diligence in one country from applying elsewhere.

\footnotetext{
${ }^{3}$ Main changes to St. Lucia's CBI program include: (i) removal of a minimum personal wealth requirement (US\$3 million); (ii) reduction of required contribution from US $\$ 200,000$ to US $\$ 100,000$ for single applicants (with a similar reduction in fees for applicants with dependents); (iii) removal of the cap of 500 citizenships per year. The bond option, which was considered the most advantageous before the changes, was discouraged with a new administrative fee of US\$50,000.
} 


\begin{tabular}{|c|c|c|c|c|c|c|c|c|}
\hline \multicolumn{9}{|c|}{$\begin{array}{l}\text { Investment Requirements of Citizenship-by-Invest } \\
\text { (In US dollars) }\end{array}$} \\
\hline \multirow{3}{*}{$\begin{array}{c}\begin{array}{c}\text { Contributions and } \\
\text { Investments }\end{array} \\
\text { Type of Application }\end{array}$} & \multicolumn{4}{|c|}{ Option I } & \multicolumn{4}{|c|}{ Option II } \\
\hline & \multicolumn{2}{|c|}{ Government Fee } & \multicolumn{2}{|c|}{$\begin{array}{l}\text { Contribution to National } \\
\text { Development Fund (NDF) }\end{array}$} & \multicolumn{2}{|c|}{ Government Fee } & \multicolumn{2}{|c|}{$\& \begin{array}{c}\text { Redeemable Investment } \\
6 /\end{array}$} \\
\hline & $\begin{array}{c}\text { Single } \\
\text { Appplicant }\end{array}$ & Family & $\begin{array}{c}\text { Single } \\
\text { Appplicant }\end{array}$ & Family & $\begin{array}{c}\text { Single } \\
\text { Appplicant }\end{array}$ & Family & $\begin{array}{c}\text { Single } \\
\text { Appplicant }\end{array}$ & Family \\
\hline Antigua and Barbuda 2/ & 50,000 & 150,000 & 200,000 & 200,000 & 50,000 & 150,000 & $\begin{array}{l}\text { Real estate: } \\
\text { 400,000 } \\
\text { Business: } \\
1,500,000\end{array}$ & $\begin{array}{c}\text { Real estate: } \\
400,000 \\
\text { Business: } \\
1,500,000\end{array}$ \\
\hline Dominica 3/ & 100,000 & 200,000 & $\ldots$ & $\ldots$ & 25,000 & 75,000 & $\begin{array}{l}\text { Real estate: } \\
200,000\end{array}$ & $\begin{array}{c}\text { Real estate: } \\
200,000\end{array}$ \\
\hline Grenada & $\ldots$ & $\ldots$ & 200,000 & 200,000 & 50,000 & 50,000 & $\begin{array}{l}\text { Real estate: } \\
350,000\end{array}$ & $\begin{array}{c}\text { Real estate: } \\
350,000\end{array}$ \\
\hline St. Kitts and Nevis 4/ & $\cdots$ & $\ldots$ & 250,000 & 300,000 & 50,000 & 125,000 & $\begin{array}{l}\text { Real estate: } \\
400,000\end{array}$ & $\begin{array}{c}\text { Real estate: } \\
400,000\end{array}$ \\
\hline St. Lucia 5/ & $\ldots$ & $\ldots$ & 100,000 & 190,000 & 50,000 & 50,000 & $\begin{array}{c}\text { Real estate: } \\
300,000 \\
\text { Business: } \\
3,500,000 \\
\text { Gov. Bonds: } \\
500,000\end{array}$ & $\begin{array}{c}\text { Real estate: } \\
300,000 \\
\text { Business: } \\
6,000,000 \\
\text { Gov. Bonds: } \\
550,000\end{array}$ \\
\hline $\begin{array}{l}\text { Sources: Country Authorities } \\
\text { 1/ Depicts minimum Investm } \\
\text { diligence and processing fee } \\
\text { 2/ A limited time offer that } r \\
\text { USD100,000 for a family of f } \\
\text { 3/ Dominica ammended pro } \\
\text { fees for real estate investmer } \\
\text { 4/ Although an explicit gove } \\
\text { by the government as budge } \\
\text { 5/ Business investment must } \\
\text { Pharmaceutical products, Po } \\
\text { announcement to change its } \\
\text { applicants, and from USD25 } \\
\text { removed. An administrative } \\
\text { 6/ For most programs, a min } \\
\text { applicants under the CIP. }\end{array}$ & $\begin{array}{l}\text { Citizenship by Ir } \\
\text { nt requirements } \\
\text { apply. } \\
\text { nained valid fro } \\
\text { ur, waiving the } \\
\text { ram requiremen } \\
\text { option. } \\
\text { Iment applicatic } \\
\text { ary fees. } \\
\text { all under one of } \\
\text { s, bridges, road } \\
\text { rogram require } \\
000 \text { to USD190, } \\
\text { e of USD50,000 } \\
\text { num holding pe }\end{array}$ & $\begin{array}{l}\text { vestment } U \\
\text { for single } v \\
n \text { the launc } \\
\text { rocessing fe } \\
\text { s effective } \\
n \text { fee is not } \\
\text { the followin } \\
\text { and highw } \\
\text { nents. The } \\
00 \text { for a fan } \\
\text { was introdu } \\
\text { iod of } 5 \text { ye }\end{array}$ & $\begin{array}{l}\text { its Guidelines; Henle } \\
\text { s. family applications } \\
\text { of the program in } 2 \\
\text { es for the two deper } \\
\text { December 2016. Char } \\
\text { required in the NDF } \\
\text { g categories: Special } \\
\text { ays, Research institut } \\
\text { equired contribution } \\
\text { nily (applicant with a } \\
\text { ced for the bond op } \\
\text { ars is required for red }\end{array}$ & $\begin{array}{l}\text { (a couple with } \\
13 \text { through e } \\
\text { dents. } \\
\text { ges include hi } \\
\text { ption of St. Ki } \\
\text { y Restaurants, } \\
\text { ons and facilit } \\
\text { to the Econon } \\
\text { pouse and up } \\
\text { on. The remai } \\
\text { eemable inves }\end{array}$ & $\begin{array}{l}\text { Id Arton Capital } \\
\text { to two depend } \\
\text {-April } 2016 \text { allo } \\
\text { ar age limit of y } \\
\text { and Nevis, abo } \\
\text { uise ports and r } \\
\text { or Offshore un } \\
\text { Fund was reduc } \\
\text { two dependen } \\
\text { g two options v } \\
\text { ent options. Ass }\end{array}$ & $\begin{array}{l}\text { ents under } \\
\text { ed for a fla } \\
\text { ung depen } \\
\text { t } 25 \text { percer } \\
\text { harinas, Agr } \\
\text { ersities. In } \\
\text { ed fro USD } \\
\text { s). The cap } \\
\text { ere left unc } \\
\text { ets maybe }\end{array}$ & $\begin{array}{l}\text { he age of 18). Addit } \\
\text { government proce } \\
\text { dents, and lower go } \\
\text { of the contributior } \\
\text {-processing plants, } \\
00,000 \text { to USD } 100,0 \\
500 \text { citizenships } \\
\text { hanged. } \\
\text { ligible for resale to }\end{array}$ & $\begin{array}{l}\text { itional due } \\
\text { essing fee of } \\
\text { overnment } \\
n \text { is retained } \\
\text { made an } \\
\text { per year was } \\
\text { future }\end{array}$ \\
\hline
\end{tabular}

\section{CInternational Monetary Fund. Not for Redistribution}




\section{References}

Xu, Sin; El-Ashram, Ahmed; and Gold, Judith; Too Much of a Good Thing? Prudent Management of Inflows under Economic Citizenship Programs; IMF Working Paper 15/193.

Dominica, Selected Issues Papers; Optimal Management of Economic Citizenship Revenues in Dominica, forthcoming.

St. Lucia, Staff Report for the 2017 Article IV Consultation; IMF, 2017. 


\section{Annex III. Central Government Wage Bills ${ }^{1}$}

Wage bills absorb a large share of ECCU countries' budgets. Many governments responded to the global financial crisis by increasing public sector employment and/or wages, which reduced budget flexibility and fiscal space. Governments are acting to contain the wage bill and reassign budgetary resources to boosting growth. Civil service reform is key to improve its cost-effectiveness over the medium term.

1. ECCU governments devote a large share of their budget to wages, nearly half of current outlays or tax revenues in some countries. The regional median wage bill is 10.2 percent of GDP, indicating that the central government is the main employer in each island. Wage bills in the region are comparable as a share of GDP with other small island developing states, which are equally affected by diseconomies of scale in assuring basic functions of government, particularly for multiislands countries.

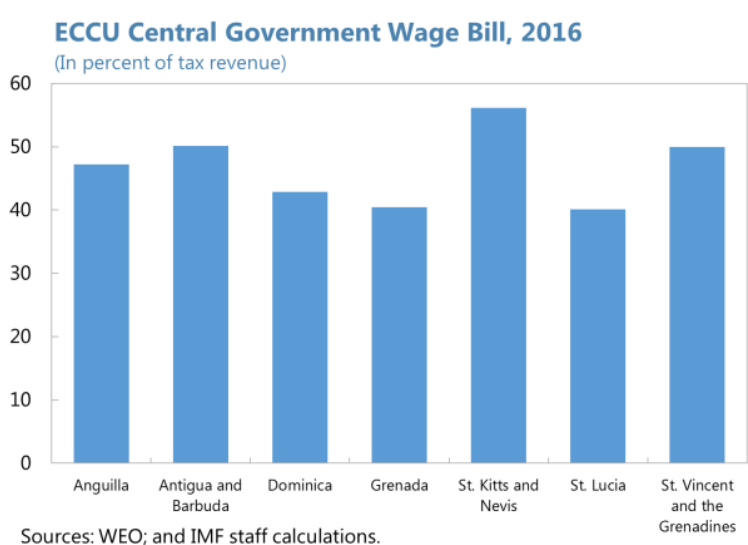

2. Without proper social safety nets, including unemployment insurance, many ECCU governments responded to the global financial crisis by increasing employment and/or wages. Countries that did not have an IMF program had more flexibility to increase both public employment and wages in the aftermath of the crisis (St. Lucia, Dominica, and mostly wages for St. 12 Vincent and the Grenadines). St. Kitts and Nevis started to increase both public wages and employment to honor commitments that predated the program.

3. To restore fiscal sustainability, enhance fiscal space, and improve the delivery of public

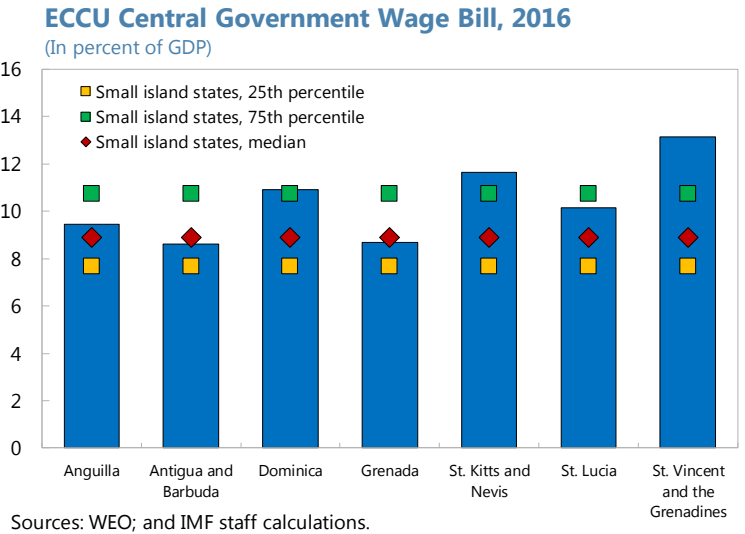
services, ECCU governments have pursued actions to contain the wage bill in recent years. These have ranged from salary freezes, ${ }^{2}$ attempts to alter the size and composition of the workforce ${ }^{3}$ to compensation reforms modifying the size and structure of pay and benefits packages. ${ }^{4}$

\footnotetext{
${ }^{1}$ Prepared by Ronald James and Wayne Mitchell.

2 Dominica in 2001 and 2003, Antigua and Barbuda (2010-12), St. Kitts and Nevis (2011-14), Grenada (2014-17), St. Lucia (2014/15 and 2015/16).

${ }^{3}$ Antigua and Barbuda's 2010-13 National Economic and Social Transformation Plan and attrition policies in Grenada and St. Lucia.

4 Dominica 2004-2006, St. Vincent and the Grenadines 2007, Antigua and Barbuda 2013.
} 


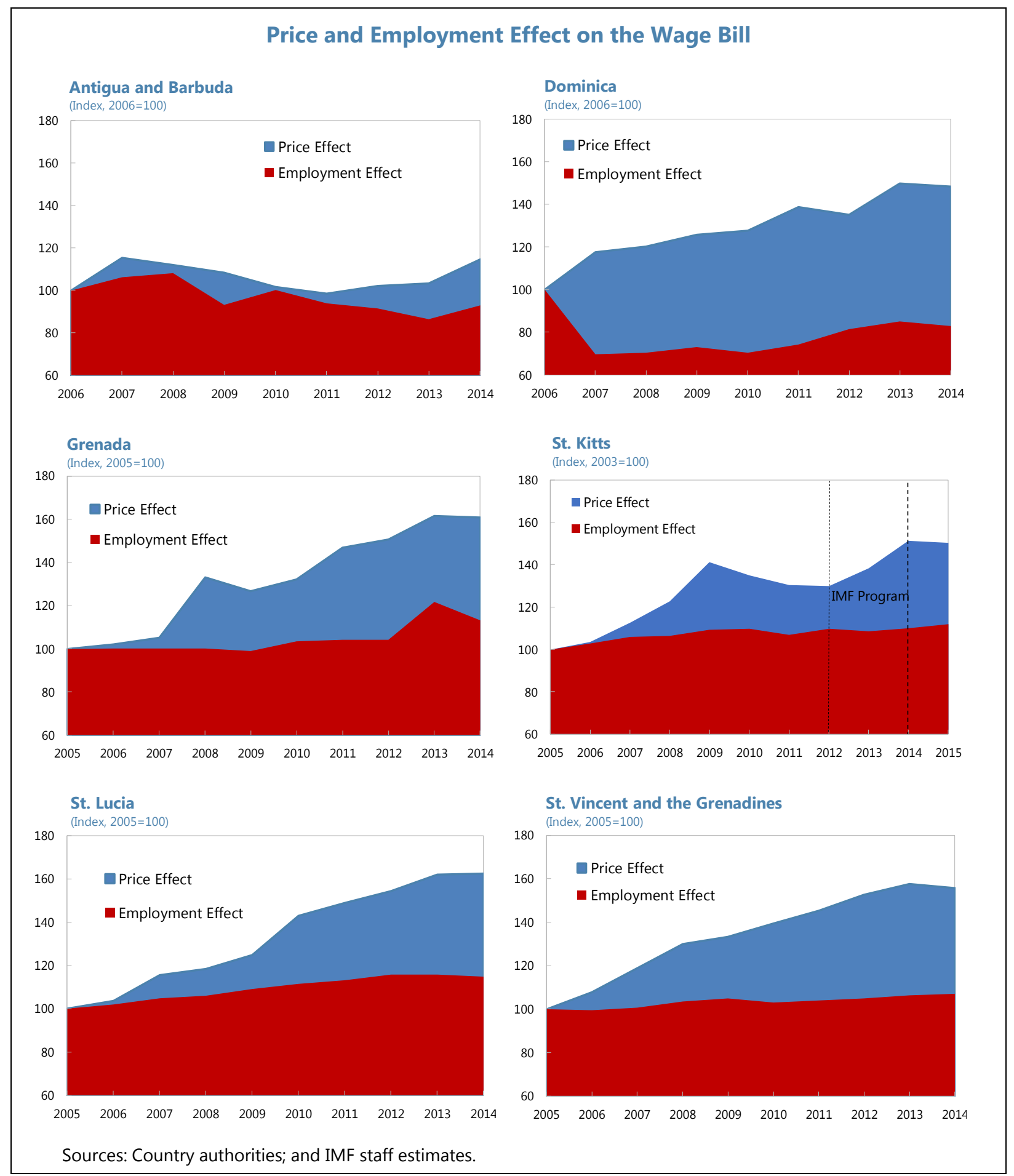

\section{More comprehensive structural reforms of the civil service are needed over the medium}

term. These would include: (i) functional reviews, to remedy critical skills in some areas and overstaffing in others; (ii) enhanced HR information systems; (iii) reviews of HR policies and processes; (iv) legal reforms addressing internal civil service procedures; and (v) reforms of compensation systems and wage setting mechanisms to internalize fiscal sustainability objectives. Grenada has developed a holistic approach to reform in a bid to improve the strategic direction, operations, and efficiency of the public 
sector and define a fair and rational system of compensation and incentives. The "Public Sector Management Reform Strategy" has four pillars: (i) re-engineering the public service to make it more efficient; (ii) strategic human resource management; (iii) wage bill reform; and (iv) an integrated ICT platform. The strategy includes a timeline for consultation with stakeholders, finalization of reforms, and implementation by 2019.

5. Strengthening social safety nets is critical to de-link public employment policies from social welfare objectives. Grenada has merged its cash transfer programs and improved their targeting while enhancing technical vocational and educational training. Over the medium term, the authorities should consider setting up a broader safety net, including unemployment insurance schemes. 


\section{Annex IV. Public Investment Management ${ }^{1}$}

Reforming the management of their public investment - including its planning, allocation and implementation - would help ECCU countries address their public infrastructure needs with fewer budgetary resources.

1. Public investment should address significant infrastructure needs. The Caribbean Development Bank has identified important gaps in the volume of economic infrastructure (measured by length of road network, electricity production, and access to water) in ECCU countries relative to a comparator group. ${ }^{2}$ When social infrastructure (number of secondary teachers and hospital beds) is considered -as in the physical infrastructure efficiency index elaborated by IMF staff- the ECCU looks much better in comparison (see chart). ${ }^{3}$ Infrastructure services -electricity, transport, water, and sanitation - need to be improved to satisfy higher service quality standards, keep pace with

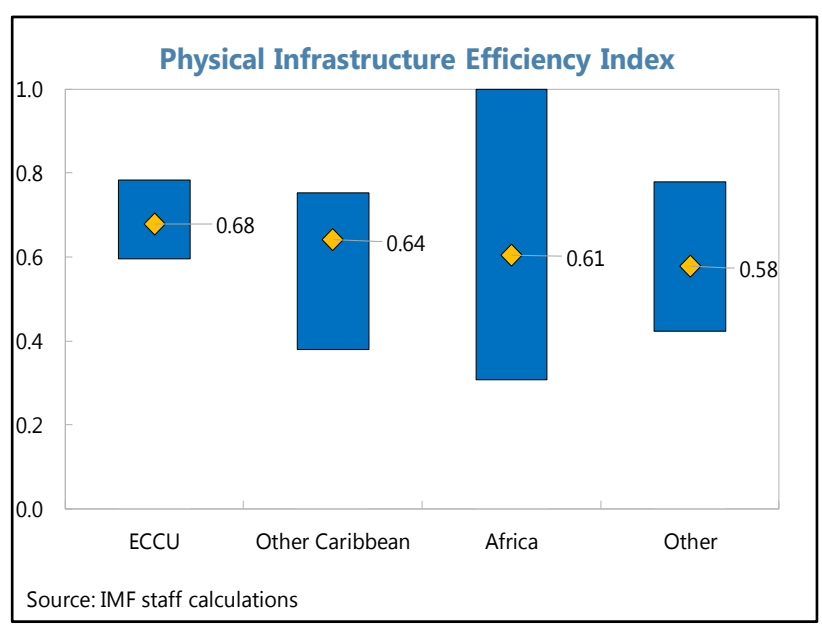
population growth, and support economic development. Public-private partnerships can help address these needs, but public sector investment remains key in ECCU countries.

2. Against a background of high indebtedness, limited fiscal space, and sluggish growth, there are concerns about the ability of ECCU countries to finance such expenditures while maintaining fiscal and debt sustainability. Infrastructure investment can spur growth and pay for itself when well executed, and lead to inefficiency and waste when not. Properly executed infrastructure investment requires a strong institutional and legal environment and adequate technical expertise in planning, allocation, and execution of public investment.

3. There are several areas where significant improvements can be made. Preliminary findings from a Public Investment Management Assessment, which examines 15 key institutions shaping public investment, shows scores ranging from 1.54 to 2.30 (average of 1.8) out of a top score of 3. The results show shortcomings in (i) planning sustainable levels of investment across the public sector; (ii) allocating investment to the right projects, the use of multiyear budgeting, and project appraisal and selection; and (iii) implementing projects on time and budget through appropriate funding, monitoring and executions as well as protecting investment through adequate maintenance.

\footnotetext{
${ }^{1}$ Prepared by Wayne Mitchell.

2 The group included five countries (Botswana, Costa Rica, Malta, Mauritius, and Seychelles). See Caribbean Development Bank, "Public Private Partnerships in the Caribbean: Building on Early Lessons", May 2014.

${ }^{3}$ The number of secondary teachers in ECCU countries is internationally high.
} 


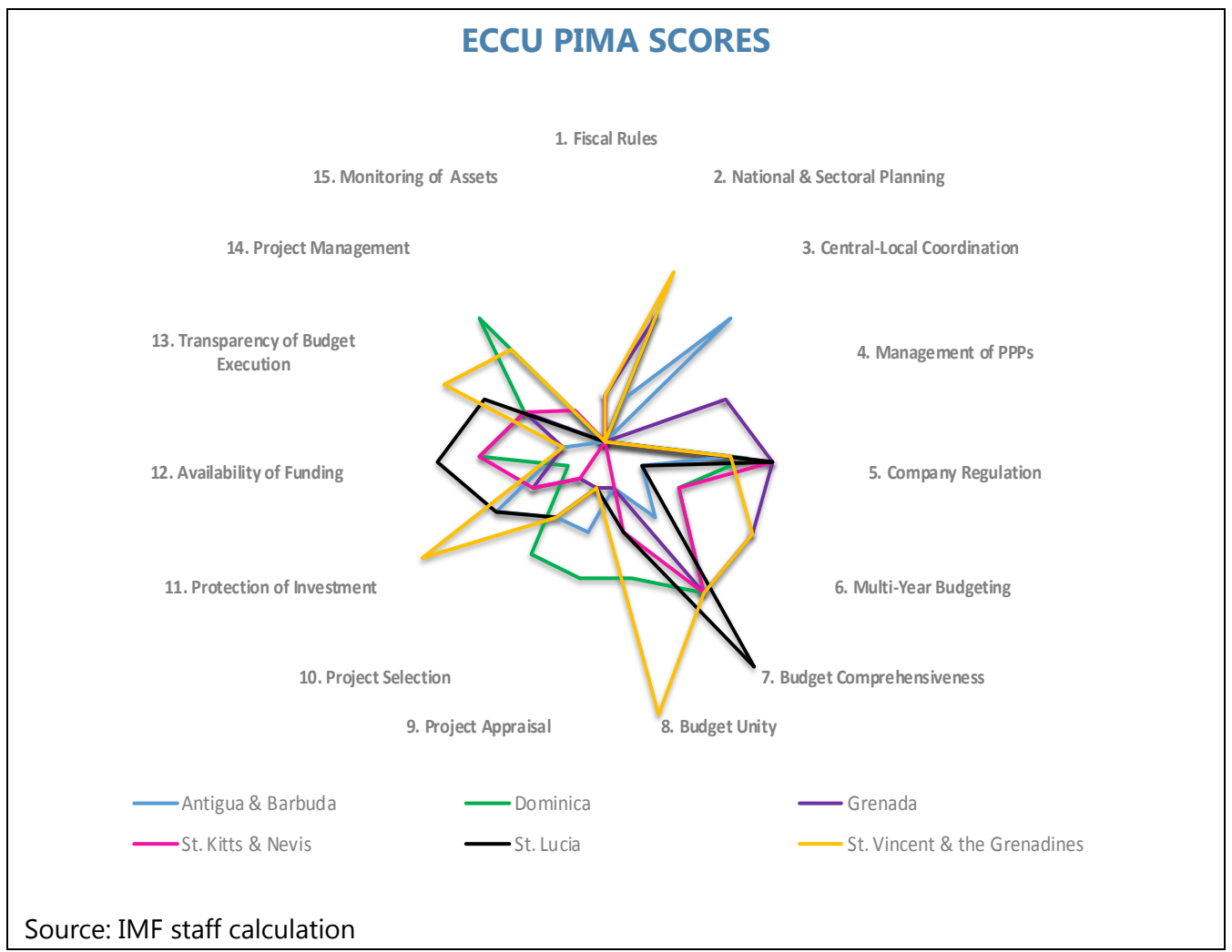

4. A targeted program to address these shortcomings, particularly in planning and implementation, can improve quality and focus of public investment and increase its return. ECCU countries are at different stages of implementing modern Public Financial Management (PFM) frameworks. Grenada has revised its new PFM legislation and adopted the associated regulations; a final draft legislation is ready in Antigua and Barbuda, St. Lucia, Anguilla, and Dominica; and St. Vincent and the Grenadines has an initial draft PFM law, which is under review. 


\section{Annex V. The Regional Government Securities' Market ${ }^{1}$}

\section{The RGSM was established in $\mathbf{2 0 0 2}$ to provide cost-effective financing for ECCU} member governments and greater risk diversification for investors. In many respects, the RGSM has been successful, and issuance has increased significantly over the years, particularly for shortterm instruments. However, the investor base remains limited to banks and public pension funds, and most governments continue to place securities over the counter (OTC) owing to swifter administrative procedures and overall lower cost, as no fees are paid to the Stock Exchange and brokers. Only St. Lucia and St. Vincent and the Grenadines, and, to a lesser extent, Grenada, issue significant volumes on the primary market. Volumes traded on the secondary market are very small.

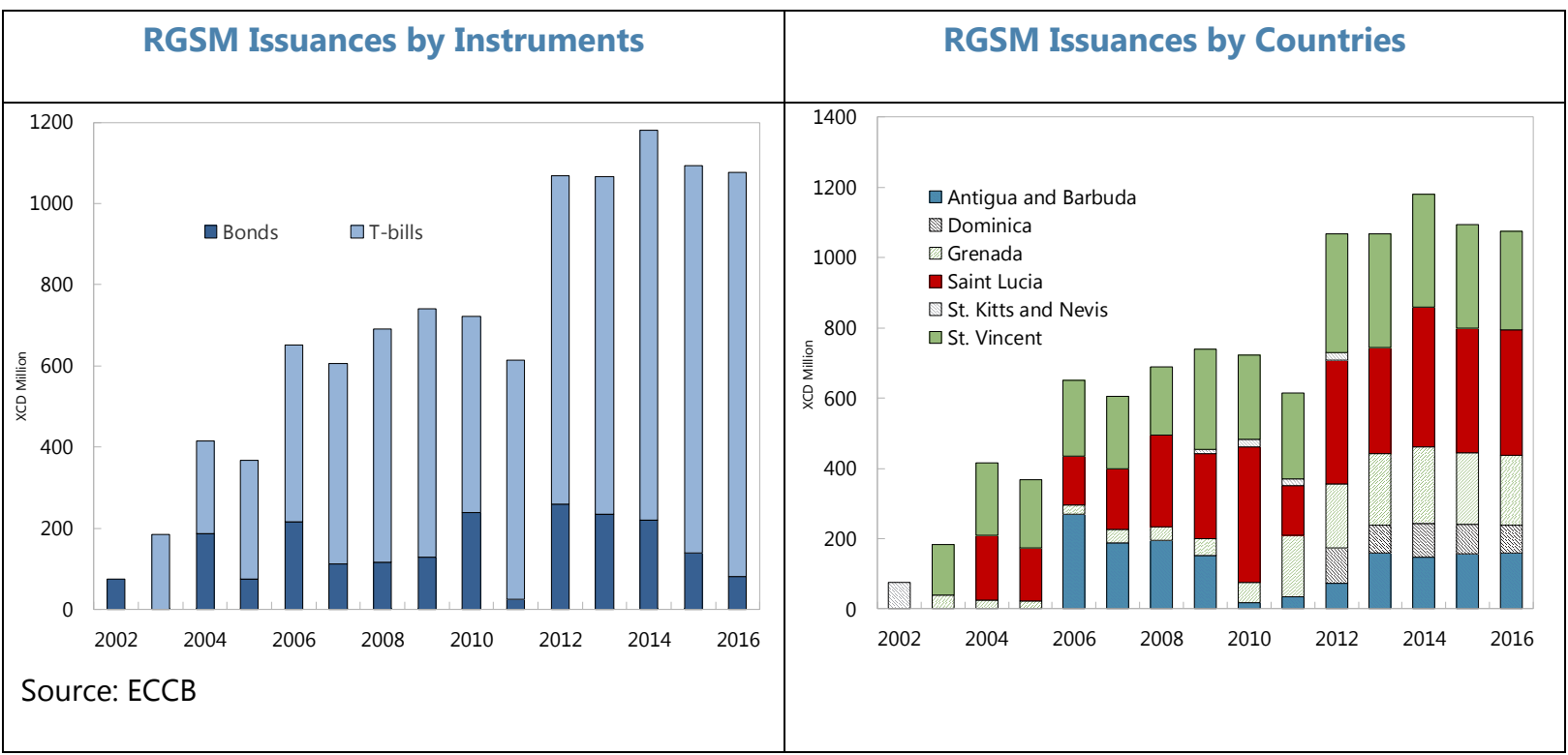

\section{The functioning of the market could be enhanced, and costs for issuers reduced.}

Primary market activity for T-bills is dominated by two of the six licensed brokers, who subscribed 84 percent of securities auctioned in 2016. Single-price competitive auctions with a reserve price take place on the trading platform of the Eastern Caribbean Security Exchange, to which government debt management offices (DMOs) have no access. Interest rates are capped, with caps set in advance for the entire year. In many auctions the final yield turns out to be equal to the cap, therefore frustrating any price discovery. Some countries can raise the initial amount offered within the limits established in the securities' prospectus. However, whenever this "top-up" option is allowed, DMOs use it entirely, thus becoming price takers. In other words, DMOs run the risk of accepting bids that contribute only marginally to achieving the total amount desired, but may be very costly to issuers because they must pay the same marginal yield to all successful bidders, as in a "single price" auction. This practice may raise considerably the final cost of the issuance (by as much

\footnotetext{
${ }^{1}$ Prepared by Diego Rivetti.
} 
as 200 basis points). Moreover, since auctions are "open", brokers have an informational advantage as they can adjust bids (increasing amounts and lowering yields) in real time. Issuance of bonds is much more limited. Single-price competitive auctions are also used, but the preferred method are subscriptions ("fixed-price auctions"), with the government fixing the price and allocations determined on a "first-come, first served" basis.

\section{Changes to some of these practices could enhance market efficiency and yield fiscal}

savings. Possible measures include: (i) establishing competitive auctions as the only issuance method; (ii) enabling DMOs to observe auctioned amounts and yields and determine cut-off prices and final amounts within the range communicated to investors; (iii) reducing incentives to issue OTC by simplifying RGSM issuance procedures and reviewing current brokers' fee structures, which are very different across countries; and (iv) modifying the rules for the top-up allocation to improve its cost effectiveness. More structural reforms could also be explored, such as introducing multi-price auctions, removing interest rate caps, and assessing if preconditions for a primary dealership can be met. 


\section{Annex VI. External Sector Assessment ${ }^{1}$}

The ECCU external position is weaker than implied by fundamentals and desirable policies. EBALite REER analysis suggests an exchange rate overvaluation ranging from 2.3 percent to 21.4 percent in 2016 (BPM5), but the assessment remains sensitive to data revisions. Weak external competitiveness is also corroborated by non-price indicators, namely high structural unemployment, increasing unit labor costs, and deficiencies in the business environment. Consequently, boosting competitiveness will require a swift implementation of structural reforms aimed at lowering the cost of doing business, increasing labor productivity, and further integrating ECCU economies.

\section{The ECCU current account is estimated to have deteriorated in 2016, largely driven by} one-off factors. The regional current account deficit is estimated to have worsened from 10 percent of GDP in 2015 to about 11.9 percent of GDP in $2016^{2}$. This deterioration was largely driven by lower exports of goods, which declined by about 10 percent year-on-year in 2016 mostly because delayed fuel re-exports in St. Lucia and a soap factory closure Dominica. Most of the current account deficit continues to be financed by FDI inflows, which - at 12.1 percent of GDP - remain well below the peak of 22 percent of GDP in 2006 and 2007, but largely in line with the 1996-2016 average of 12 percent of GDP.

\section{Revised BPM6 statistics, which are expected to be released later this year, are likely to} present smaller external deficits throughout the region. The ECCB, in cooperation with national statistical offices, is soon expected to release external sector statistics for 2014 and 2015, based on BPM6 methodology and updated surveys. Preliminary estimates for 2014 released in 2015 show a current account deficit on average 10 percent of GDP lower than in previous BPM5-based estimates BPM6 current account balance figures also showed the misalignment virtually eliminated or even changing sign in EBA-Lite (see ECCU staff report 2016 and 2015). Most of the differences were driven by changes to methodology and coverage. Specifically, BPM6 estimates rely on updated visitor expenditure data, and expanded coverage to include a broader group of respondents, such as offshore universities. Regional authorities continue revising and improving the Balance of Payments statistics.

\footnotetext{
1 Prepared by Alla Myrvoda

${ }^{2}$ Based on the BPM5 methodology.
} 


\section{REER Misalignment}

\section{While the INS-based REER shows some appreciation in real terms since 2014,} customer-based REER has remained broadly in line with historical averages. The observed appreciation of the customer-based REER is relatively low given the large weight of the U.S. as a trading partner and the fixed nominal exchange rate to the U.S. dollar. Competitor-based REER also shows limited misalignment as currencies of some competitors are also linked to the US dollar. The INS-based REER, on the other hand, which reflects the largest number of trading partners, shows an appreciation of 7.6 percent over three years between end-2013 and end-2016.

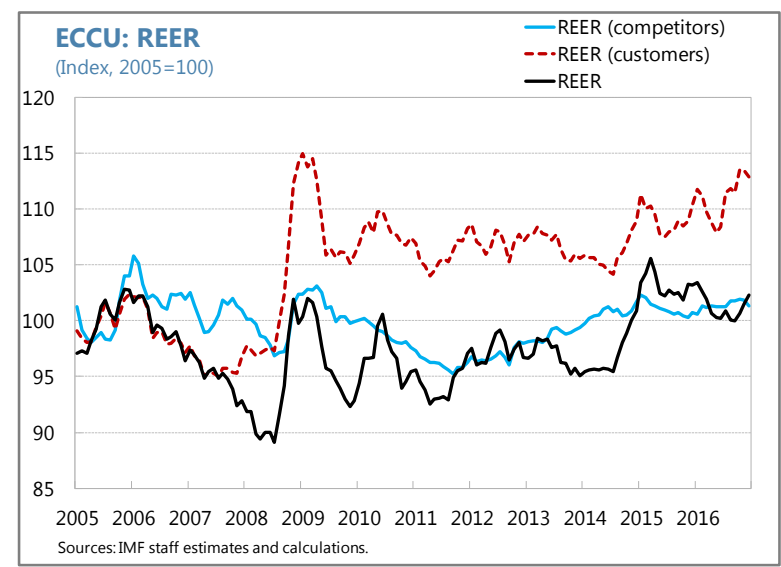

\section{The estimated REER misalignment figures are substantially affected by the} methodology and data revisions. As the authorities are currently in the process of migrating the balance of payments statistics from BPM5 to BPM6, the new external sector statistics are likely to change significantly given the use of updated expenditure surveys and broadening of coverage. Estimates based on BPM5 present a significant discrepancy between regressions based on the current account and those based on REER estimates, partly reflecting the poor fit of the model for small tourist-dependent economies exposed to natural disasters. For instance, current accountbased regressions point to an average overvaluation of about 21 percent in 2016, but regressions based on index REER indicate an overvaluation of 2.3 percent on average, with a wide variation among countries.

\begin{tabular}{|c|c|c|c|c|c|c|c|}
\hline & \multicolumn{6}{|c|}{ CA regression } & \multirow{3}{*}{$\begin{array}{l}\text { I-REER regression } \\
\text { REER GAP }\end{array}$} \\
\hline & Current & Actual Current & Current & Policy & & REER & \\
\hline & Account Norm & Account Balance & Account Gap & Gap & Residual & $\mathrm{GAP}^{2}$ & \\
\hline Antigua and Barbuda & -2.5 & -5.9 & -3.4 & 4.0 & -7.4 & 12.2 & -6.0 \\
\hline Dominica & 1.1 & -11.8 & -12.9 & 1.9 & -14.8 & 50.0 & 5.3 \\
\hline Grenada & -6.6 & -14.6 & -8.0 & 1.6 & -9.6 & 21.8 & -11.1 \\
\hline St. Kitts and Nevis & -4.4 & -16.0 & -11.6 & 6.6 & -18.2 & 18.4 & 8.2 \\
\hline St. Lucia & -5.5 & -6.7 & -1.2 & -0.4 & -0.9 & 4.4 & 7.8 \\
\hline St. Vincent and the Grenadines ${ }^{2}$ & -4.6 & -18.9 & -14.4 & 1.4 & -15.8 & $\ldots$ & 9.9 \\
\hline ECCU simple average & -3.7 & -12.3 & -8.6 & 2.5 & -11.1 & 21.4 & 2.3 \\
\hline \multicolumn{8}{|c|}{$\begin{array}{l}{ }^{1} \text { Assessment for 2016. Based on September, } 2016 \text { WEO vintage. Estimates may differ from individual staff report due to data revisions or } \\
\text { vintage variation. } \\
{ }^{2} \text { Estimate for St. Vincent and Grenadines is excluded to avoid biasing the regional average due to poor model fit caused by high FDI flows } \\
\text { related to airport construction. Poor model fit in part reflects the impact of natural disaster shocks. }\end{array}$} \\
\hline
\end{tabular}




\section{Non-price indicators}

\section{Non-price indicators point to weak} competitiveness in the region, driven by labor market rigidities and high costs of doing

business. Data show that while wages increased over the last decade, productivity has continued to decline since the onset of the financial crisis, thus, contributing to rising unit labor costs and weakening competitiveness within the region. Stagnant economic activity, labor skills mismatches, labor market rigidities, future economic uncertainty, and migration are often cited as the main causes of low productivity and high unemployment.

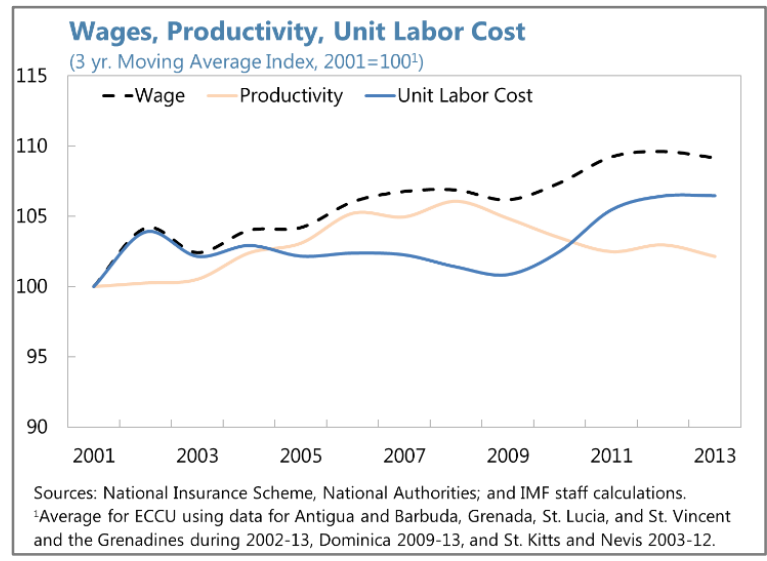

\section{Labor market data in the ECCU show persistently high levels of unemployment,} particularly among the youth. In some ECCU countries, the long-term decline in agricultural employment following the downsizing of the banana industry has not been fully absorbed by the public sector or tourism, leading to high levels of structural unemployment. There is evidence that high wages in public sector and tourism increase the reservation wage and that skills mismatches are prevalent. Strong and politically influential unions add rigidity to the wage setting process. ${ }^{3}$ The increase in unemployment in many ECCU countries since the global financial crisis also points to a significant cyclical component of the high unemployment rates in recent years. Since the start of the financial crisis, unemployment rates increased most significantly in St. Lucia, Antigua and Barbuda, and St. Vincent and the Grenadines, while employment programs in St. Kitts and Nevis helped contain unemployment. Youth unemployment is considerably higher than the overall unemployment rate in all ECCU countries. The ratio of youth to total employment, however, is similar to that of other regions, including Latin American and other Caribbean countries.

\footnotetext{
${ }^{3}$ See Lafeuillee, J., R. James, G. Salinas and Y. Savchenko "Explaining High Unemployment in ECCU Countries", IMF working paper, forthcoming.
} 

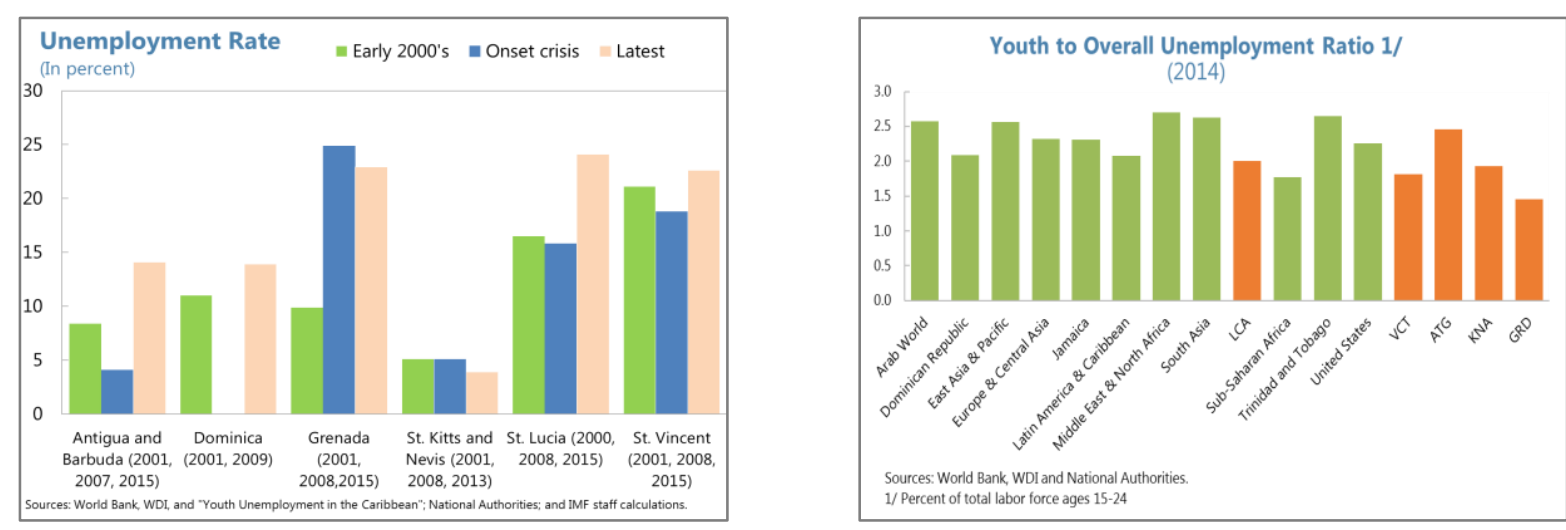

7. Difficulties to access credit and weak insolvency framework are major impediments to

doing business. As suggested by the World Bank

Doing Business Indicators, rigidities in the

business environment continue to persist in many

ECCU countries. For instance, access to credit and insolvency resolution in all the member states remain well below LAC and OECD averages. The ease of trading across borders, registering property, and paying taxes largely are in line with LAC averages, but well below advanced

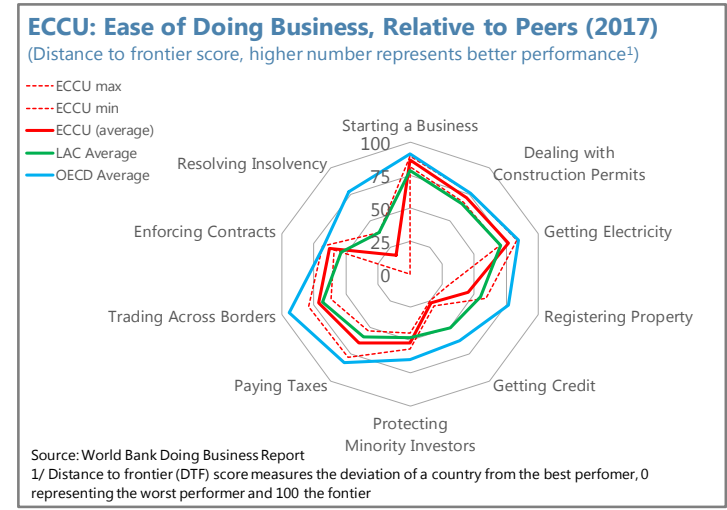
economies.

\section{Reserve Adequacy}

8. The ECCU's reserve position further improved in 2016, reaching an all-times high. At EC $\$ 4.5$ billion at end-2016, gross international reserves covered about 6.1 months of prospective imports, well exceeding the 3-month cover benchmark. Similarly, reserve coverage was well above 20 percent of broad money and 100 percent of foreign currency deposits in 2016. Over the medium term, reserve accumulation is expected to decelerate reflecting the recovery of domestic activity.

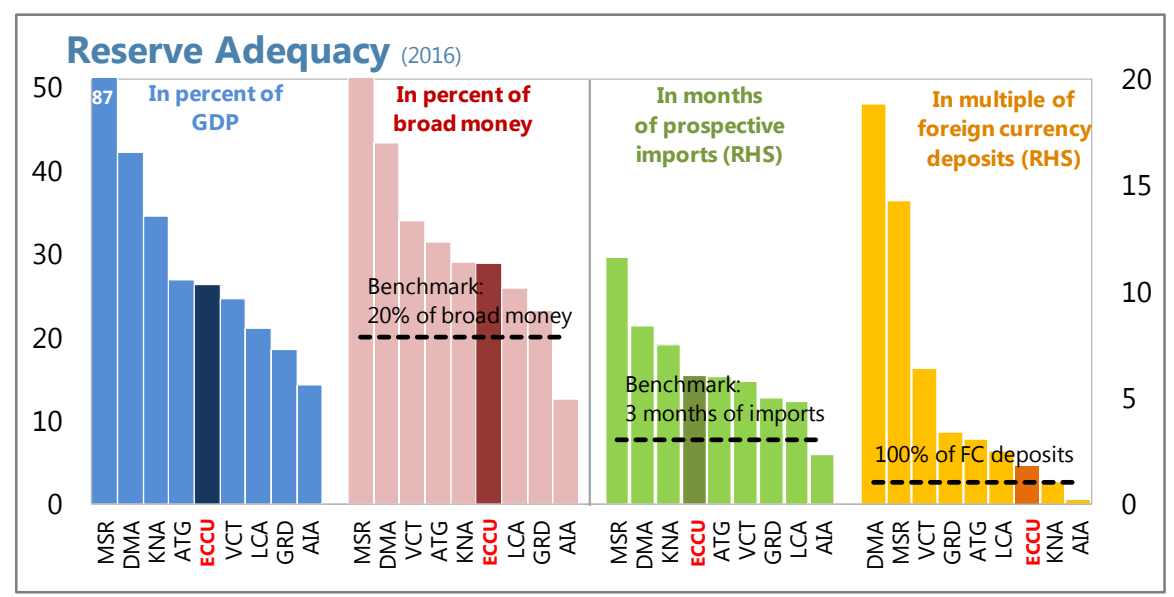




\section{Annex VII. United Kingdom Overseas Territories-Anguilla and Montserrat ${ }^{1}$}

\section{Anguilla}

1. Economic activity in Anguilla continues to recover, mostly driven by tourism. Real GDP grew by 3.8 percent in 2016, but it did not extend across all sectors. Value added in hotels and restaurants grew by 10 percent, and, with tourism accounting for about 35 percent of the Anguillan economy, other sectors were positively affected. While mining and construction also experienced strong growth, activity declined in agriculture, manufacturing, and the financial sector, reflecting the resolution of two intervened banks.

\section{The resolution of two insolvent banks in April 2016 led to a sizable increase in public} debt. To support the banks' resolution, the government issued a new bond and contracted a loan from the Caribbean Development Bank for a total of EC $\$ 325$ million, which brought public debt-toGDP to 47 percent in 2016 from 24.6 percent in 2015. After receiving a waiver by the U.K. for noncompliance with its fiscal rules, the Anguillan government remains committed to achieving its fiscal targets by 2028 and significantly strengthening bank supervision and regulation. Debt repayment requires an effective effort in recovering nonperforming loans, as well as higher primary balances based on spending control and continued U.K. capital grants. With a 75 percent NPLS recovery — which may be optimistic - , to return public debt to its pre-resolution level by 2022, the primary fiscal surplus should increase from an average of 2.2 percent of GDP in the last 5 years to 4.3 percent over the next 5 years.

\section{The government is undertaking a significant fiscal adjustment. The fiscal measures} included in the FY2016/17 budget are expected to improve Anguilla's fiscal position by raising the primary surplus to 6.2 percent of GDP in 2017. Infrastructure projects have been postponed and capital expenditure for 2016 was well below the budgeted amount. Capital revenue is projected to rise from 0.5 percent of GDP in 2016 to 6 percent of GDP in 2017, primarily because of EDF funds, U.K. government grants, and the sale of ANGELEC shares. Revenues and grants are expected to increase in 2018 reflecting the introduction of a new tax on AirBnB accommodations and improvements in tax administration and compliance.

\section{The growth outlook largely depends on the effective implementation of the} authorities' plan. Growth is expected at $23 / 4$ percent in the medium term, based on continued growth of tourism, return to normalcy in the banking system, and success of the fiscal consolidation effort. U.K. grants will be instrumental to the expansion of tourism infrastructure and improvement of competitiveness, with EC $\$ 20$ million allocated to the development of Road Bay Jetty and additional funds assigned to the production of a National Economic Development Plan. Nonetheless, given high amortization payments associated with the banking resolution and future restrictions on borrowing from the U.K. government, a strong turn-around in revenues is needed to

\footnotetext{
${ }^{1}$ Prepared by Daniela C. Hess and Hanlei Yun.
} 
avoid cash flow constraints. Economic recovery also requires a normalization of credit to the economy, which is expected to recover following the bank resolution. Considering global regulatory initiatives, reliance on the offshore financial sector as a source of growth should be reconsidered.

\section{Montserrat}

5. Preliminary indicators point to strengthening economic growth. GDP is estimated to have grown by 3.6 percent in 2016, up from 0.3 percent in 2015, underpinned by a sharply accelerating construction activity and robust activity in tourism, with visitors increasing by 4 percent and cruise ship passenger arrivals rising by 40 percent. Consumer price inflation turned negative for the fourth year in a row, reflecting favorable international commodity prices. The fiscal balance deteriorated markedly to -0.3 percent on the back of lower grants. Public debt remains very low at 5.3 percent of GDP. Credit to private sector increased by 3.9 percent while deposit accumulation remained flat. The current account deficit increased to 9.8 percent of GDP, mainly because of large data revisions (Table 2).

6. The growth outlook will be enhanced by the realization of key government projects. Over the medium term, economic growth is projected to average about 2.2 percent of GDP. Social programs to improve health and education, combined with capital projects to support and enhance tourism, energy, and construction are critical to unlocking growth. Efforts continue to expand access to social housing, upgrade health and educational infrastructures, and to improve social and human development. In addition, the authorities are implementing infrastructure projects aimed at improving roads and bridges, upgrading electricity distribution, water distribution, and waste management systems. The construction of a new port will improve cruise tourism and connectivity to the island. A resumption of strong, sustainable growth is necessary to reduce reliance on U.K. grants, which finance about 70-80 percent of total expenditures.

7. The authorities target total independence from fossil fuels by 2020. The authorities aim to exploit favorable conditions for solar, wind, and geothermal energy production, which would reduce the island's exposure to volatile oil prices and lower high energy costs. Combined with easier access to the island by tourism, this would significantly reduce the costs of doing business. 


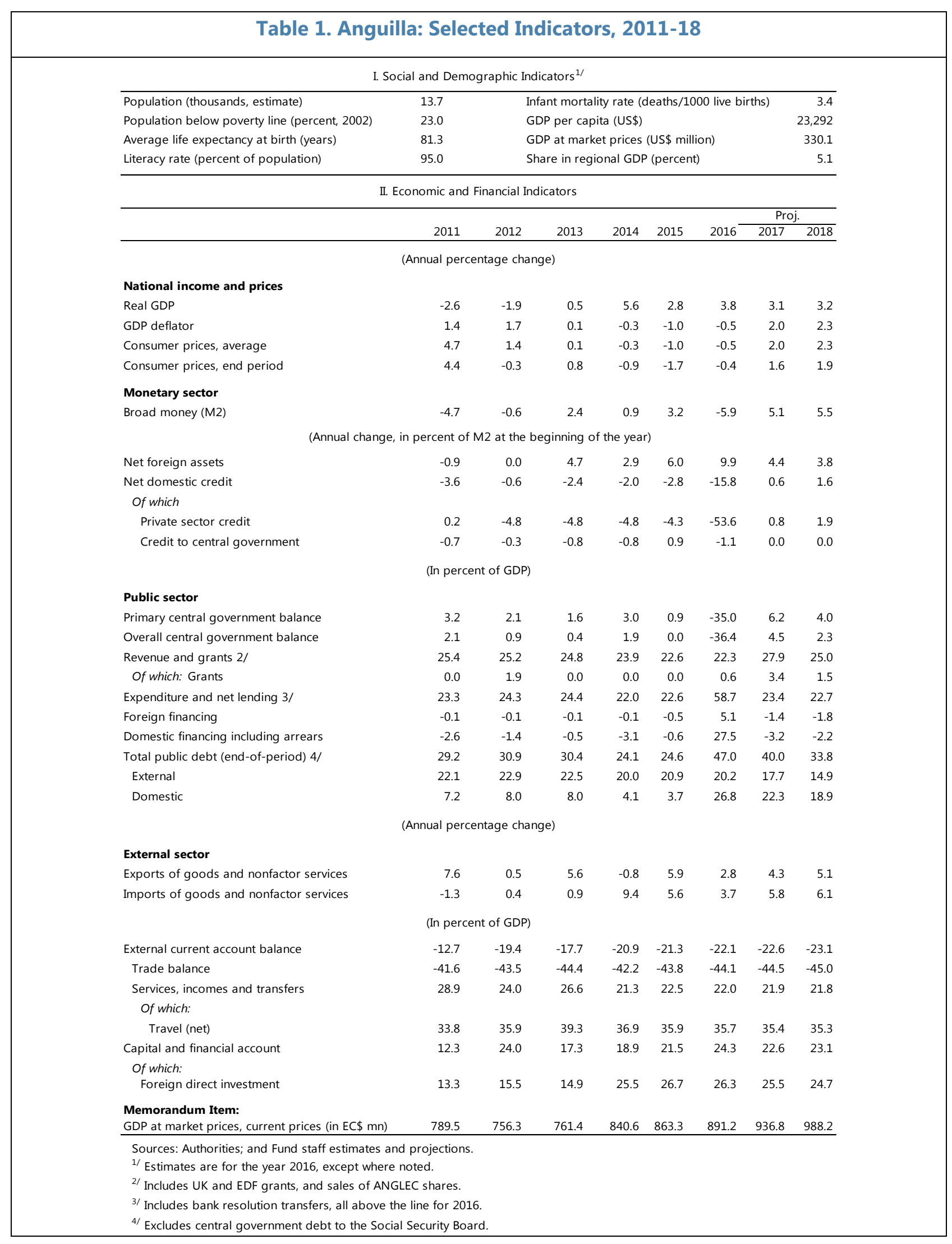

\section{CInternational Monetary Fund. Not for Redistribution}


Table 2. Montserrat: Selected Indicators, 2011-18

I. Social and Demographic Indicators $1 /$

\begin{tabular}{lrlr}
\hline Population (thousands, estimate) & 5.2 & Gini coefficient & 0.3 \\
Average life expectancy at birth (years) & 73.2 & GDP per capita (US\$), estimate $\quad 11,387$ \\
Literacy rate (percent of population) & 97.0 & GDP at market prices (US\$ mln) & 59.2 \\
Infant mortality rate (deaths / 1000 live births) & 15.8 & Share in regional GDP (percent) & 1.0
\end{tabular}

II. Economic and Financial Indicators

\begin{tabular}{lllllllll} 
& & & & & Est. & \multicolumn{2}{c}{ Proj. } \\
\cline { 5 - 7 } & 2011 & 2012 & 2013 & 2014 & 2015 & 2016 & 2017 & 2018
\end{tabular}

(Annual percentage change)

National income and prices

Real GDP

GDP deflator

Consumer prices, average

Consumer prices, end-period

$\begin{array}{llllllll}6.2 & 1.6 & 5.3 & 0.3 & 0.3 & 3.6 & 1.7 & 2.0\end{array}$

$\begin{array}{llllllll}5.3 & -1.5 & 0.9 & -0.4 & -1.1 & -0.2 & 1.0 & 1.5 \\ 3.7 & 4.8 & 0.9 & -0.4 & -1.1 & -0.2 & 1.0 & 1.5\end{array}$

Monetary sector

Broad money (M2)

$\begin{array}{llllllll}4.4 & 3.6 & -0.5 & -0.9 & -0.1 & -1.3 & 1.0 & 1.5\end{array}$

$\begin{array}{llllllll}13.0 & 14.7 & -2.5 & 11.1 & 2.4 & 1.0 & 2.7 & 3.5\end{array}$

(Annual change, in percent of $M 2$ at the beginning of the year)

Net foreign assets

Net domestic assets

Of which:

Private sector credit

$\begin{array}{rrrrrrrr}26.5 & 25.7 & -4.0 & 8.4 & 13.6 & -4.3 & 6.1 & 4.9 \\ -13.6 & -11.0 & 1.5 & 2.7 & -11.2 & 5.2 & -3.3 & -1.3 \\ & & & & & & & \\ 3.9 & 3.5 & -3.8 & 0.1 & 1.5 & 3.9 & 1.9 & 1.8\end{array}$

(In percent of GDP)

$\begin{array}{rrrrrrrr}7.7 & -7.0 & -17.0 & -6.1 & 21.6 & -0.3 & 7.2 & 4.2 \\ 7.7 & -7.0 & -17.0 & -6.2 & 21.6 & -0.3 & 7.1 & 4.1 \\ 78.0 & 82.6 & 95.8 & 94.3 & 113.5 & 78.9 & 92.9 & 85.9 \\ 54.0 & 57.5 & 69.9 & 65.9 & 85.1 & 51.3 & 65.0 & 57.6 \\ 70.3 & 89.7 & 112.9 & 100.5 & 92.0 & 79.2 & 85.8 & 81.8 \\ -0.1 & -0.1 & -0.1 & -0.1 & 2.0 & 0.0 & -0.1 & -0.1 \\ -7.6 & 7.1 & 17.1 & 6.2 & -23.5 & 0.3 & -7.0 & -4.1 \\ 14.2 & -8.6 & -21.7 & -1.7 & 14.9 & 4.2 & 7.1 & 4.1 \\ 4.7 & 4.3 & 4.7 & 4.3 & 6.0 & 5.3 & 4.8 & 4.3\end{array}$

(Annual percentage change)

\section{External sector}

Exports of goods and nonfactor services

Imports of goods and nonfactor services

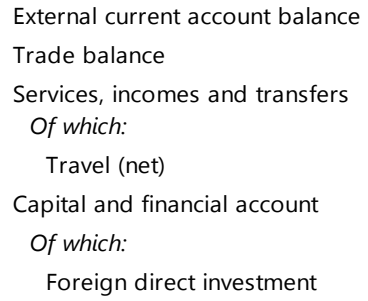

External current account balance

Trade balance

Services, incomes and transfers

Of which:

Travel (net)

Capital and financial account

Of which:

Foreign direct investment

Memorandum item:

GDP at market prices, current prices (in EC\$ mn)

\begin{tabular}{rrrrrrrr}
18.0 & 4.9 & 25.8 & -11.6 & -1.1 & 2.9 & 5.0 & 4.1 \\
11.7 & 7.0 & 29.7 & -20.4 & -4.9 & -5.2 & 19.5 & -3.2 \\
\multicolumn{2}{r}{ In percent of GDP) } & & & & & & \\
-15.8 & -21.7 & -48.8 & -20.3 & -2.8 & -9.8 & -10.7 & -10.2 \\
-42.8 & -49.5 & -52.6 & -56.2 & -52.8 & -44.7 & -55.2 & -49.3 \\
27.0 & 27.8 & 3.9 & 35.9 & 49.9 & 34.8 & 44.5 & 39.0 \\
8.1 & 11.2 & 11.4 & 13.9 & 14.3 & 13.9 & 14.1 & 14.2 \\
26.0 & 31.1 & 65.6 & 28.0 & 13.0 & 15.1 & 15.1 & 13.4 \\
& & & & & & & \\
3.9 & 4.2 & 6.3 & 10.5 & 7.0 & 6.7 & 7.0 & 6.9 \\
& & & & & & & \\
172.0 & 168.8 & 160.6 & 159.3 & 159.9 & 170.6 & 175.3 & 181.4
\end{tabular}

d projections.

Sources: Authorities; ECCB; and Fund staff estimates and projections.

1/ Estimates are for the year 2016, except where noted. Balance of payments 2014 onwards projections (BPM5 methodology).

\section{CInternational Monetary Fund. Not for Redistribution}




\section{INTERNATIONAL MONETARY FUND}

\section{EASTERN CARIBBEAN CURRENCY UNION}

STAFF REPORT FOR THE 2017 DISCUSSION ON COMMON

May 18, 2017 POLICIES OF MEMBER COUNTRIES-INFORMATIONAL ANNEX

$\begin{array}{ll}\text { Prepared By } & \text { The Western Hemisphere Department } \\ \text { (In consultation with other departments) }\end{array}$

\section{CONTENTS}

RELATIONS WITH THE FUND $\underline{\underline{2}}$ 


\section{RELATIONS WITH THE FUND}

(As of March 31, 2017)

1. Membership Status: Not Applicable

2. Exchange Arrangement: The Eastern Caribbean Currency Union (ECCU) comprises six Fund members: Antigua and Barbuda, Dominica, Grenada, St. Kitts and Nevis, St. Lucia, and St. Vincent and the Grenadines; and two territories of the United Kingdom, Anguilla and Montserrat. The eight ECCU members have a common currency, monetary policy, and exchange system. The common currency, the Eastern Caribbean (EC) dollar, has been pegged to the U.S. dollar at the rate of EC $\$ 2.70$ per U.S. dollar since July 1976 . The common central bank, the Eastern Caribbean Central Bank (ECCB), has operated like a quasi-currency board, maintaining foreign exchange backing of its currency and demand liabilities of close to 100 percent.

3. Safeguards Assessment: The 2016 updated safeguards assessment found that the ECCB continues to maintain a governance framework that provides for independent oversight. Transparency in financial reporting has been maintained and the external audit mechanism is sound. The ECCB is taking steps to restructure the internal audit and risk management functions to align them with leading international practices.

\section{CARTAC: CAPACITY BUILDING IN THE ECCU}

(As of March 30, 2017)

4. The Caribbean Regional Technical Assistance Center (CARTAC) was established in November 2001 to provide technical assistance (TA) and training to beneficiary countries, currently 21, ${ }^{1}$ and to the Eastern Caribbean Central Bank (ECCB). CARTAC is financed by development partners, its members, and by the IMF, and is hosted by the Government of Barbados. On January 1, 2017 CARTAC entered its fifth phase of operations. CARTAC's core areas of TA and training include revenue administration, public financial management (PFM), macroeconomic programming and analysis, financial sector stability and supervision, and economic and financial statistics.

5. In FY2017 the ECCU region accounted for just over 24 percent of $\mathrm{TA}^{2}$ to the CARTAC membership (Figure 1), with a particular focus on financial sector supervision, revenue administration and statistics (Figure 2). Dominica, St. Lucia and St. Vincent and Grenadines are the most intense users of CARTAC TA amongst the ECCU countries.

\footnotetext{
${ }^{1}$ Preparations are ongoing to extend CARTAC membership to Aruba, and St. Maarten.

${ }^{2}$ Measured in mission weeks, including time spent supporting countries from CARTAC.
} 


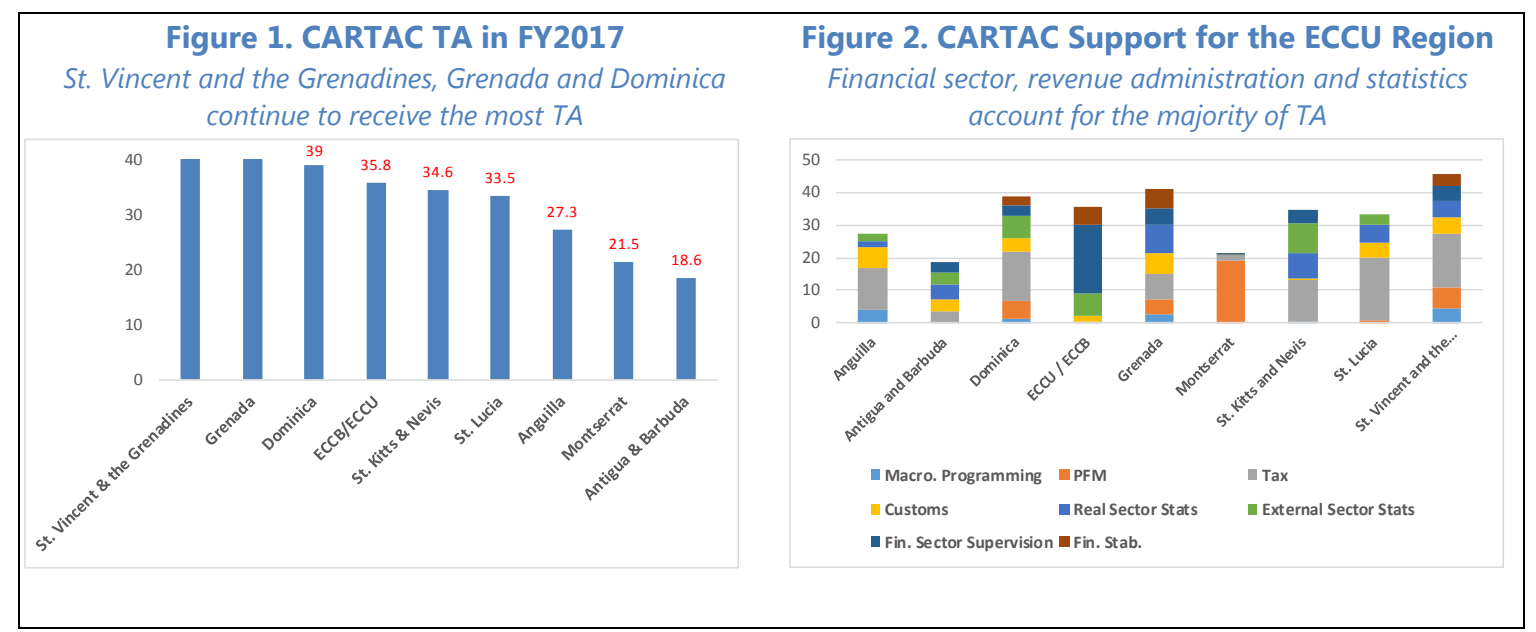

6. Highlights of CARTAC's TA and training to the ECCU countries in the various core areas are provided below.

\section{In the area of tax administration, VAT implementation in ECCU countries is} largely complete. ${ }^{3}$ The tax program for the ECCU member countries continues to focus on: (i) organizational restructuring to include strengthening and establishing a large taxpayer operation, (ii) strategic performance management; (iii) capacity building in core functions (taxpayer service, audit, collections enforcement, data analysis and risk management), and (iv) building of a robust headquarters function.

8. Implementation of management of taxpayers through segmentation and the establishment of Large and Medium Taxpayers Units (LMTUs) and Design, Planning and Monitoring Units (DPMUs) are progressing well in Dominica, St. Lucia, St. Kitts and Nevis, Grenada, and St. Vincent and the Grenadines.4

9. Several countries are furthering their tax reform agendas, strengthening their institutional and policy frameworks, and improving the ease of administration:

- St. Lucia - the Corporate Income Tax (CIT) regime was reviewed; a presumptive tax was designed for implementation in FY17 - awaiting the tabling of the 2017 budget; the VAT threshold was increased to EC $\$ 400,000$ effective on February 1, 2016 and the VAT standard rate was reduced to 12.5 percent in February 2017. LMTU and HQ functions were established, and benefited from TA in developing a compliance risk management plan, a taxpayer service strategy and strengthening performance management.

\footnotetext{
3 Dominica (March 2006), Antigua and Barbuda (January 2007), St. Vincent and the Grenadines (May 2007), Grenada (February 2010), St. Kitts and Nevis (November 2010), St. Lucia (October 2012). In Anguilla in 2012, CARTAC provided support with its preparations for the introduction of a Goods and Services Tax in 2014 -the Government is considering a broad-based GST/VAT, possibly to be implemented in two phases - Limited VAT in 2019 and full VAT in 2022

${ }^{4}$ Segmentation - LMT is operational - however, not fully integrated into a single unit.
} 
- Dominica - the VAT threshold was increased to EC\$250,000 in September 2016. Discussions are ongoing with stakeholders on the CIT regime and implementation of a presumptive tax.

- Grenada - has reformed its tax incentives regime and the supporting legislation is now fully implemented.

- Anguilla - a joint tax policy/tax administration mission provided recommendations on reforming indirect taxation and tax administration.

- St. Kitts and Nevis - CARTAC provided advice on implementing and managing a tax incentive regime. Several legislative amendments have been passed including strengthening the collections enforcement provisions, and the new organizational structure and staff appointments have been approved and implemented.

\section{A standardized regional approach to compliance and data analysis is being} rolled-out as a 'regional initiative.' Given the significant capacity gaps in the region, this project aims to build analytical skills in the planning, monitoring and program design and audit units to improve data matching and data mining to strengthen the quality of compliance management programs. In FY2017 the data analysis program was delivered in St. Kitts and Nevis, Dominica, St. Lucia, and Grenada, and is to be rolled out in St. Vincent and the Grenadines in early FY2018.

\section{With assistance, Dominica has put a taxpayer service strategy in place.}

Performance management was strengthened through building capacity/mentoring of officers in the planning and monitoring units in St. Lucia, Antigua and Barbuda, and St. Kitts and Nevis. Antigua and Barbuda also benefited through building capacity/mentoring of officers in area taxpayer segmentation

12. St. Lucia and Grenada are now producing timely and more accurate reporting. Tax administration information technology (IT) system, largely used in the ECCU countries, is receiving regional peer-to-peer support. Drawing on regional skills, IT enhancement support was provided to St. Lucia and Grenada through enhancements to SIGTAS. This has assisted the authorities to produce timely and more accurate reports, and to automate the provisions of the new TAPA in Grenada including revised interest and penalty regimes being programed for application to taxpayer accounts. An integrated IT solution and development of a taxpayer identification numbering system has been recommended for Montserrat.

\section{In supporting regional integration, all ECCU member countries benefited from} four regional workshops in FY2017: (a) International Survey of Revenue Administration (ISORA) sensitization sessions led by FAD staff were delivered to a strong contingent of country participants; (b) Tax Administration Diagnostic Assessment Tool (TADAT) - countries were guided through the assessment tool and methodology used to assess the effectiveness of a tax administration against international good practice, and how they can use the method to self-assess their current state and to use the assessment to build their reform/work program; (c) Leadership Symposium - this is a new addition to the slate of regional events which was delivered collaboratively by CARTAC's tax and customs program. The core objective 
of the CARTAC Leadership Initiative (CLI) was to target executive and senior management personnel to optimize the potential for sustainable leadership capacity in revenue administrations across the region; (d) Institutionalizing Performance Management in Tax Administration.

14. Customs administration focuses on: (i) leadership, management and governance; (ii) strategic Planning; (iii) human resource development; (iv) trade facilitation; and, (v) compliance. Regional initiatives include continued support to CARICOM and the OECS in the harmonization of procedures, economic integration and free circulation of goods regime; and, in partnership with CCLEC, delivering leadership and management training.

15. TA has been provided to St. Kitts and Nevis and St. Vincent and the Grenadines to prepare corporate business and strategic plans, and all now have some form of corporate plan in use. In Anguilla CARTAC experts conducted organizational structure reviews and workload assessments to help the planning function.

16. Risk Management is the corner stone of an effective, modern customs administration. It enables customs, by gathering and analyzing information from a variety of sources, to make sound decisions about intervening in the cargo clearance process. St. Vincent and the Grenadines and Anguilla, and in each a framework has been prepared to identify, categorize and prioritize risks, and to propose risk treatments to address those risks.

17. TA, including advice, mentoring and training on post clearance audit (PCA), was delivered to St. Kitts and Nevis, St. Lucia, and Dominica. Approximately 20 officers received training, and as a result of this assistance, customs in these member countries now have the capacity to initiate significant PCA programs, and to strengthen both compliance and trade facilitation. Together with risk management, PCA has been an area where CARTAC has provided significant amounts of TA in FY16-to Antigua and Barbuda, Dominica, and St. Kitts and Nevis. While external factors, such as legislative constraints, have limited the ability to fully operate PCA systems, improvements can already be seen in all of these administrations. In Dominica, approximately $\$ 700,000$ in additional duties and taxes was assessed by the PCA unit in 2015; in St. Kitts and Nevis, 13 audits were carried out in 2014/2015 with assessments of approximately $\$ 100,000$ being made.

18. TA, that included guidance, mentoring and training, was provided in valuation in Grenada; and training in tariff classification was provided in Dominica, Antigua and Barbuda, and St. Vincent and the Grenadines. In Grenada, additional duties and taxes assessed by customs in relation to classification and valuation has shown progressive year on year increases from US $\$ 25,000$ in 2012 to US $\$ 120,000$ in 2014. Training was provided to about 83 officers, and will mean increased consistency, fewer disputes with importers, faster clearance and, importantly, enhanced revenue collection.

19. In support of the planned OECS free movement of goods regime, a study and workshop to analyze trade and revenue data was delivered by CARTAC. Work was also initiated to consider revenue management options for the free circulation regime. Due to data limitations the exercise was not completed, however, sufficient analysis was possible to give 
OECS member governments adequate information and the confidence to press forward with the free circulation plan. CARTAC will continue to be engaged in this area, and at the request of the OECS will undertake a study to provide information and possible options to help decision-makers harmonize customs service charges.

20. To ensure that the opportunities presented by the new international airport in St. Vincent and the Grenadines airport are optimized, CARTAC provided advice on customs procedures to safeguard against smuggling, and facilitate processing of tourists and other travelers. Training was provided to officers in risk assessment and control techniques.

21. With a view to assessing the progress in public financial management reform, CARTAC has undertaken a comparative review of PFM practices in ECCU member countries $^{5}$ against overall characteristics of a "core PFM" framework ${ }^{6}$ as defined in the IMF Good Practice Note (GPN) on 'Sequencing PFM Reform' (Diamond, 2013). This analysis has produced a number of interesting findings regarding the standard of PFM across the ECCU region, and in turn informed allocation of CARTAC resources.

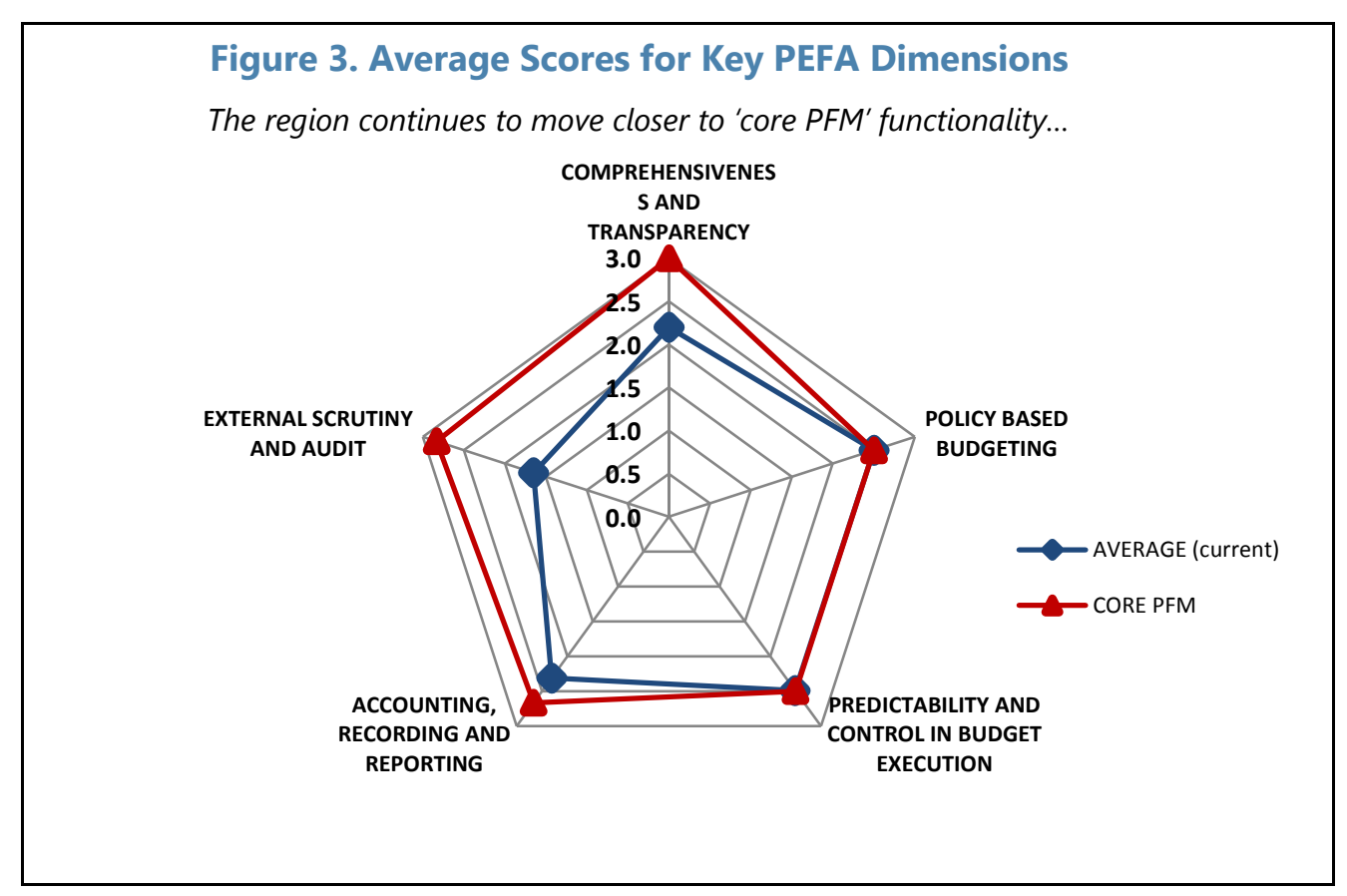

\footnotetext{
${ }^{5}$ Analysis was derived from the PEFA assessments conducted from 2013-2016 in Anguilla, Antigua and Barbuda, Dominica, Grenada, Montserrat and St. Kitts and Nevis. Dominica and St. Kitts assessments while finalized were yet to be peer reviewed.

${ }^{6}$ As defined in the IMF Good Practice Note (GPN) on 'Sequencing PFM Reform' (Diamond, 2013).
} 
22. New PEFA asessments completed in Grenada and Dominica in 2016 will add to this information base, with St. Lucia also scheduled for assessment during the summer of 2017. As a follow-up to each PEFA assessment CARTAC works closely with the assessed countries to develop PFM Action Plans to improve those weaknesses highlighted in the PEFA assessments.

23. Implementation of a modern and consistent PFM legal framework across the ECCU is progressing. Antigua and Barbuda (implemented by IMF Headquarters with European Union funding), St. Lucia (under the Financial Management in the Caribbean program ${ }^{7}$ ) Anguilla and Dominica have final draft legislation for legislative consideration. In September a FAD led TA Mission to Dominica on the establishment of a Vunerability, Risk and Resilience Fund (VRRF) to mitigate financial shocks from severe weather events. CARTAC provided amendments to their Draft PFM Legislation governing the creation, operation and management of the VRRF Fund. Montserrat and St. Vincent and the Grenadines also have initial PFM drafts under review. Grenada passed revisions to its new PFM legislation and has adopted revised regulations (FMC).

24. Anguilla, Montserrat, and St. Vincent and the Grenadines received diagnostic assessments and training in the implementation of the CARTAC SOE/SB ownership manual (bringing to seven the number of countries implementing the manual). The countries undergoing this reform were bought together in a small workshop early in 2016 to share experiences and better practices in implementing the CARTAC reform - Grenada gave a compelling presentation on achievements to date and shared reporting templates and other material to aid the reform effort in the region.

25. Regional budget preparation reform has been strengthened, with new countries adopting the strategic budgeting reform agenda. St. Lucia's budgets were prepared according to the strategic budget reform methodology and presented in the revised program budgeting format, including non-financial performance information. St. Vincent and the Grenadines completed their pilot exercise in 2016 and have now recently tabled their 2017 Estimates of Revenue and Expenditure containg ministerial priorities and output and outcome information for their programs. Budget preparation reform was further sustained through the development of comprehensive budget manuals. New manuals were developed for St. Lucia and St. Vincent and the Grenadines; bringing to nine the number of CARTAC countries with comprehensive budget preparation manuals. The budget manuals include a gender budgeting perspective.

26. Compliance with International Public Sector Accounting Standards (IPSAS) has made great progress. The annual IPSAS cash basis workshop was repeated during the year to evaluate compliance with the new exposure draft. As a result, Anguilla, and St. Kitts and Nevis were selfassessed as fully compliant, however work remains to improve the notes to cash basis financials, to provide a more comprehensive view as countries move to modified cash (prior to accrual basis). A mission to Dominica to review their Treasury Functions and to improve their IPSAS cash management also took place.

27. During FY17, Grenada and Dominica were the recipients of diagnostics to assist the authorities to further develop their internal audit function for compliance with international

\footnotetext{
${ }^{7}$ FMC - Financial Management in the Caribbean program financed by Canada and executed by the Fiscal Affairs Department (FAD).
} 
standards. Furthermore, the annual regional workshop in FY17 covered risk management and the role of internal audit as an independent assurance for management.

28. The ECCU has been a major recipient of technical assistance in macroeconomic analysis and programming. Over the past year, training and TA efforts have concentrated on strengthening institutional structures for policy making, as well as core training in macroeconomic and fiscal foreasting. Two regional workshops were delivered, with the first focusing on macroeconomic forecasting, and the second on revenue forecasting and tax policy analysis. ECCU member states had a strong representation at both workshops.

\section{The concerted effort to implement macroeconomic forecasting capabilities} within ECCU Ministries of Finance led to improved capacities. Grenada, St. Lucia, St Kitts and Nevis, and Anguilla, are all taking active roles in this vital function as a direct result of TA from CARTAC. In all these countries, CARTAC-designed frameworks are now being utilized by the authorities. In order to underpin the annual Budget process with a sound medium-term macroeconomic framework, missions were conducted in Anguilla, Dominica and St. Vincent and the Grenadines to strengthen those countries' medium-term fiscal frameworks.

30. CARTAC's TA in the area of financial stability revolves around: (i) stress-testing various aspects of the financial system; (ii) preparing financial soundness indicators (FSIs) for deposit-taking institutions, and financial stability and health indicators (FSHIs) for the nondeposit taking segments of the financial sector; (iii) developing macro-prudential and systemic risk indicators (MPSIs and SRIs respectively) to bolster overall financial sector risk management and, in a few instances, (iv) assisting countries to refine their financial stability reports.

\section{Work in the area of stress testing dominated CARTAC's financial stability work} plan during FY16. Considerable progress was made with the conduct of an extensive dynamic modeling and stress-testing exercise of seven domestic and four international banks spread across the ECCU region (Antigua and Barbuda, Dominica, Grenada, St. Kitts and Nevis, Montserrat, St. Lucia, and St. Vincent and the Grenadines). The major focus of the project was to help the ECCB assess the financial situation of key banks in the ECCU region, as well as to enhance the capacity of staff to conduct regular stress tests of the ECCU banking system. This multi-country TA project served as an important complement to a larger project being undertaken by the IMF, the World Bank and the Caribbean Development Bank (CDB). In addition, specialized internal seminars on stress-testing and macro-prudential indicators were delivered for around 20 regulatory staff of the ECCB and for the Grenada Authority for the Regulation of Financial Institutions (GARFIN).

\section{During FY17, work on stress testing and dynamic modeling was consolidated} with further stress tests of the nine indigenous banks. CARTAC and MCM completed a scoping mission with the ECCB to assess financial stability needs in the ECCU region and to coordinate TA efforts. A roadmap of programs was delivered and outcomes to be achieved were compiled and agreed with the ECCB which include (a) risk monitoring (stress-testing the NBFIs, development of macro-prudential and systemic risk indicators and financial soundness indicators for the non-banks), (b) macro-prudential policy framework (including legal mandate and toolkit), (c) financial crisis management planning at an ECCU-wide level, (d) consolidated 
supervision, (e) analysis of financial sector interconnectedness ( $f$ ) quality assurance of onsite examinations (f) methodology for SIFIs in non-banks and (g) Basel Implementation. Some work also begun on stress testing non-bank financial institutions, starting with credit unions.

\section{In the area of building financial resilience (by developing effective crisis} management plans and resolution strategies), work focused inter alia on: (i) training GARFIN staff on crisis management and resolution frameworks, and (ii) improving the capacity of regulators in all segments of the financial system on crisis prevention, preparedness/management, and resolution frameworks. CARTAC conducted training on financial crisis management for the regulatory staff of GARFIN and in conjunction with the Central Bank of Barbados, hosted a three-day Conference on the theme "Building Resilience to Financial Crises in the Caribbean: The Role of Crisis Management Policies, Metrics and Plans" in March 2016. This Conference brought together 74 stakeholders from national regulatory authorities, the regional regulatory associations and key international bodies (including the IMF, World Bank and the FSB) to discuss how the Caribbean region could best approach the design of institutional and operational frameworks to withstand financial sector and economywide disruptions. ${ }^{8}$ Drawing on new information presented at this conference, some ECCU members (Grenada and St. Vincent and the Grenadines) have approached CARTAC for technical assistance in strengthening their national financial sector crisis preparedness plans and resolution frameworks. Work in the medium term will focus on developing crisis management plans at a national level in the various ECCU territories which could serve as a pre-cursor to the ECCU-wide plan. Headquarters has already made arrangements for a longterm expert on financial supervision at the ECCB.

34. In the area of financial reporting, CARTAC also worked with the ECCB to train staff on financial stability reporting, and to review and strengthen the first draft of the ECCU financial stability report.

35. With regard to financial sector supervision, eighteen of the 20 CARTAC member countries are now fully on board to implement the standardized approach to Basel II in the Caribbean. During FY16, the ECCU adapted the revised Basel reporting forms, and the following Basel Guidelines: (i) credit risk; (ii) operational risks; (iii) market risks; (iv) interest rate risk in the banking book; (v) supervisory review process (pillar II), and disclosure and transparency (pillar III).

36. During FY16, several of the single regulatory authorities in the ECCU have also requested TA to implement Basel II for the off-shore banking sector. To this end, CARTAC has provided TA to Antigua and Barbuda, St. Vincent and the Grenadines, St. Lucia, and St. Kitts and Nevis to review their supervisory frameworks to ensure adequacy to implement Basel II. Antigua and Barbuda have already submitted the revised reporting forms and guidelines to their off-shore banking industry for comments and feedback.

\footnotetext{
${ }^{8}$ Some key areas covered in the Conference include (a) Key Components of a Well-Designed Crisis Management Plan (b) Legal and Institutional Foundations for Crisis Management (c) Resolving Systemically Important Cross-Border Institutions: Resolution Plans, Tools and Financing Options (d) Simulating Financial Crisis Management Plans and (e) Developing Appropriate Financial Safety Nets.
} 
37. Antigua and Barbuda, Dominica, Montserrat, St. Lucia, St. Vincent and the Grenadines, and St. Kitts and Nevis were the recipients of TA aimed at: (i) building capacity/training in risk-based supervision (RBS); (ii) documenting and formalizing their approach to risk-based supervision, and (iii) developing risk profiles for credit unions, insurance companies, pension funds and securities firms. RBS guidelines were reviewed to include: (i) the assessment of risk profiles in financial institutions; (ii) assessment of inherent risks such as credit, market, operational, strategic and reputational risks; and (iii) assessment of corporate governance oversight and governance functions and supervisory interventions as well as assessing the impact of risks on the firm's capital, profitability and liquidity. The RBS framework for Antigua and Barbuda is now published on the authority's website, and the authorities have incorporated the RBS framework in their onsite reviews of banks and nonbanks as well as the offsite surveillance and monitoring of financial institutions.

\section{Three regional workshops were held during FY16 for the non-bank sectors} (insurance, pensions and securities). Eighty eight persons, representing 18 of 20 CARTAC member countries, participated in the insurance workshop, while the pensions workshop had 69 participants, representing 17 of the 20 CARTAC member countries. The insurance workshop focused on several key issues including cross border supervision, capital adequacy, solvency and stress testing, and conduct and disclosure; while the pension workshop focused on crisis management, risk based supervision, managing investments and offsite surveillance. The securities training workshop was held April 20-22 in The Bahamas with approximately 40 participants. The workshop focused on capital markets development, payment and settlement systems, risk-based supervision, and crisis preparedness. Follow-up on earlier training provided indicated that the authorities have incorporated training content into their on-site review and offsite monitoring of licensed financial institutions.

\section{During the year, CARTAC in collaboration with the Caribbean Association of} Credit Union Supervisors (CACS) held its regional credit union training workshop under the theme "Strengthening Credit Union Supervision and Regulation in the Caribbean." Regional regulators were trained on credit risk/loan review, risk weighted capital adequacy requirements, risk assessment and stress testing, supervisory intervention and corporate governance. Key among the challenges facing regulators as discussed during the workshop were: (i) inordinate delays in promulgating regulations for credit union supervision in the ECCU; (ii) challenges in passing legislation in some countries; (iii) transition from self-regulated organizations (SROs) such as credit union leagues, to an independent regulator such as the central bank, and (iv) poor credit quality evidenced by high levels of non-performing loans.

\section{TA was also provided to:}

- The first CARTAC regional financial sector strategic meeting focused on: (a) regional financial sector supervision and stability issues, challenges and TA responses; (b) financial sector reform; (c) macro prudential surveillance; (d) crisis management; (e) Basel II/III implementation, and $(f)$ risk-based supervision.

- The financial stability and financial sector supervision programs jointly hosted the financial strategic workshop with 59 participants drawn from the banking, insurance, 
pension, credit union, and capital market regulatory authorities in 17 CARTAC member countries. The objectives of the financial stability aspect of the workshop were to: (a) provide training in the areas of macro-prudential policy formulation as well as macroprudential indicators and systemic risk measures; (b) identify weaknesses in the financial stability frameworks of member states; and (c) to gauge the on-going impact of the newly-established financial stability program.

41. During 2015-16 the CARTAC program on economic and financial statistics concentrated on improving external sector, national accounts and prices statistics in ECCU countries. Good progress is being made by a number of countries in expanding the range and improving the quality of their annual national accounts. A comprehensive review of the national accounts was completed for Anguilla; with a detailed action plan developed to implement improvements. For St. Lucia, several methodological improvements were implemented and revised annual GDP by economic activity (GDP-P) estimates have been compiled for 2006-2015. Improved methodologies to be used to compile GDP by expenditure (GDP-E) estimates have been developed for Grenada and St. Kitts and Nevis; and improved annual GDP-E estimates have been released for St. Vincent and the Grenadines.

- Increased efforts are being made by countries to develop or improve quarterly national accounts estimates. Grenada and St. Lucia are now producing quarterly GDP-P estimates at both current and constant prices; while quarterly constant price GDP-P estimates are being compiled for St. Vincent and the Grenadines.

- Progress is also being made by countries to improve prices statistics and inflation management. Staff have been trained and an improved prices data collection (including a new rents' survey) has been implemented for Antigua and Barbuda.

42. CARTAC is continuing to coordinate its activities with other TA providers in the region, including the Project for the Regional Advancement of Statistics in the Caribbean (PRASC) ${ }^{9}$ being delivered by Statistics Canada on improving data sources and compiling national accounts and prices statistics; the assistance provided by the ECCB in reviewing the annual national accounts of its member states; and the consultants engaged by the Caribbean Community Secretariat during 2015 and 2016 to provide broad level advice on implementing the 2008 System of National Accounts (2008 SNA).

43. External sector statistics (ESS) focus on supporting the improvement of methodologies and compilation practices to better measure external transactions (balance of payments - BOP) and positions (international investment position - IIP), through the adoption of good practices and the latest internationally accepted guidelines and standards.

\footnotetext{
${ }^{9}$ The PRASC is a Canadian Government funded initiative being implemented by Statistics Canada over 2015-2022. The participating states include Antigua and Barbuda, the Bahamas, Barbados, Belize, Dominica, Grenada, Guyana, Jamaica, Montserrat, St. Kitts and Nevis, St. Lucia, St. Vincent and the Grenadines, Suriname, and Trinidad and Tobago.
} 
44. ECCU's balance of payments (BOP) data has been reviewed and IIP data produced for first time. Preliminary aggregated 2014 BOP and IIP statistics following the BPM6 methodology were produced and released by the ECCB in coordination with national statistics offices for the eight ECCU members and the ECCU in January 2016. The ECCB plans to publish comprehensive 2014 and 2015 balance of payments and IIP data soon. The estimates benefited from CARTAC TA to develop and administer new surveys, and train data compilers and survey respondents. CARTAC continue assisting ECCU members in reviewing the recent revisions and identify balance of payments components that need further improvement.

45. Visitor and student expenditure data have improved in the ECCU economies. Estimates of visitor expenditure, included as travel services exports in the balance of payments, are now based on recent surveys of visitors. The correct inclusion of tuition fees and other education-related travel services provided by offshore universites (OUs) to nonresident students as part of the ECCU exports is among the most significant methodological changes introduced in the updated methodology. A specific ESS survey form of OUs has been implemented and administrative data used as complementary sources. In the case of Antigua and Barbuda, over 450 students were also surveyed in collaboration with the former office of the IMF's Resident Representative for the ECCU region. 